Environmental Restoration Division ORNL Environmental Restoration Program

\title{
Toxicological Benchmarks for Wildlife
}

D. M. Opresko,

B. E. Sample, and G. W. Suter

Date Issued-September 1993

\section{OAK RIDGE NATIONAL LABORATORY}

Oak Ridge, Tennessee 37831-6285 managed by

MARTIN MARIETTA ENERGY SYSTEMS, INC.

for the

U.S. DEPARTMENT OF ENERGY under contract DE-AC05-84OR21400 


\section{CONTENTS}

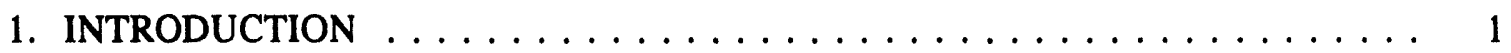

2. AVAILABILITY AND LIMITATIONS OF TOXICITY DATA $\ldots \ldots \ldots \ldots \ldots$

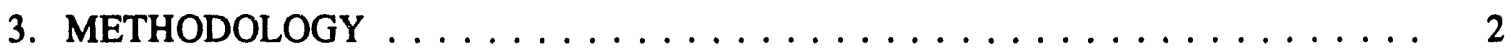

4. APPLICATION OF THE METHODOLOGY $\ldots \ldots \ldots \ldots \ldots$

4.1 INORGANIC TRIVALENT ARSENIC $\ldots \ldots \ldots \ldots \ldots$

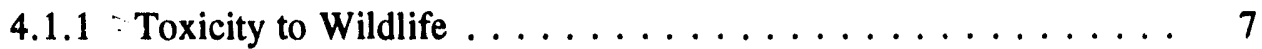

4.1.2 Toxicity to Domestic Animals . . . . . . . . . . . 8

4.1.3 Toxicity to Laboratory Animals (Rodents) . . . . . . . . . . . . 9

4.1.4 Extrapolations to Wildlife Species . . . . . . . . . . . . 10

4.2 POLYCHLORINATED BIPHENYLS $\ldots \ldots \ldots \ldots \ldots \ldots \ldots$

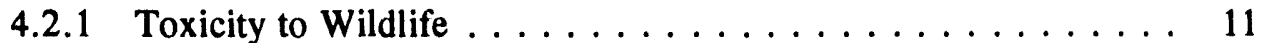

4.2.2 Toxicity to Domestic Animals . . . . . . . . . . . . . 11

4.2 .3 Toxicity to Laboratory Animals . . . . . . . . . . . . . . 11

4.2.4 Extrapolations to Wildlife Species . . . . . . . . . . . 13

5. SITE-SPECIFIC APPLICATION OF THE METHODOLOGY $\ldots \ldots \ldots \ldots \ldots \ldots$

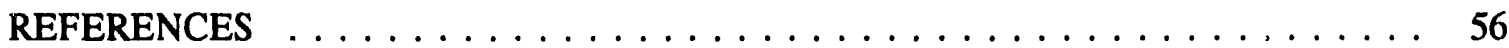

APPENDIX A Selected Toxicity Data for Avian and Mammalian Wildlife . . . . . . . A-1

APPENDIX B NOAELs and LOAELs for Laboratory Animals . . . . . . . . . . . B-1

APPENDIX C Common Species of Mammals and Birds Found on the Oak Ridge

Reservation ......................... C-1 


\section{TABLES}

1. Toxicity of Trivalent Arsenic Compounds to Wildlife . . . . . . . . 7

2. Toxicity of Trivalent Arsenic

Compounds to Domestic Animals . . . . . . . . . . . . . . . . 8

3. Toxicity of Trivalent Arsenic

Compounds to Laboratory Animals . . . . . . . . . . . . . . 9

4. Selected Wildlife Toxicity Values

for Trivalent Inorganic Arsenic . . . . . . . . . . . . . . . 12

5. Toxicity of Aroclor 1254 to Wildlife $\ldots \ldots \ldots \ldots \ldots$

6. Toxicity of Aroclor 1254 to Laboratory Animals . . . . . . . . . . . . 13

7. Selected Wildlife Toxicity Values for Aroclor $1254 \ldots \ldots \ldots$

8. Aquatic Food Chain Multiplying Factors $\ldots \ldots \ldots \ldots$

9. Body Size Scaling Factors $\ldots \ldots \ldots \ldots \ldots$

10. Extrapolation Factors $\ldots \ldots \ldots \ldots \ldots \ldots \ldots \ldots \ldots$

11. Octanol-Water Partition Coefficients, Water Solubility Data

and Bioconcentration Factors $\ldots \ldots \ldots \ldots 21$

12. Toxicological Benchmarks for Selected

Mammalian Wildlife Species . . . . . . . . . . . . . . . 23

13. Toxicological Benchmarks for Selected Avian

Wildlife Species . . . . . . . . . . . . . . . . . . . . 48 


\section{ACRONYMS and ABBREVIATIONS}

$\begin{array}{ll}\text { BAF } & \text { Bioaccumulation Factor } \\ \text { BCF } & \text { Bioconcentration Factor } \\ \text { bw } & \text { Body Weight } \\ \text { DOE } & \text { United States Department of Energy } \\ \text { EPA } & \text { United States Environmental Protection Agency } \\ \text { FCM } & \text { Food Chain Multiplier } \\ \text { FEL } & \text { Frank Effects Level } \\ \text { LD } & \text { Lethal Dose to 50 percent of the population } \\ \text { LOAEL } & \text { Lowest Observed Adverse Effects Level } \\ \text { NOAEL } & \text { No Observed Adverse Effects Level } \\ \text { Pot }_{\text {oct }} & \text { Octanol/Water Partition Coefficient } \\ \text { PCB } & \text { Polychlorinated Biphenyl } \\ \text { RfD } & \text { Reference Dose } \\ \text { RTECS } & \text { Registry of Toxic Effects of Chemical Substances } \\ \text { TCDD } & \text { Tetrachlorodibenzodioxin } \\ \text { TCDF } & \text { Tetrachlorodibenzofuran } \\ \text { TWA } & \text { Time Weighted Average }\end{array}$




\section{ACKNOWLEDGMENTS}

This manuscript has benefitted from the review comments of Tom Ashwood, Bob Young, Ruth Hull, and Bobette Nourse. 


\section{INTRODUCTION}

The process by which the ecological risks of environmental contaminants is evaluated is twotiered. In the first tier, a screening assessment is performed where concentrations of contaminants in the environment are compared to toxicological benchmarks. These benchmarks represent concentrations of chemicals in environmental media (water, sediment, soil, food, etc.) that are presumed to be nonhazardous to the biota. While exceedance of these benchmarks does not indicate any particular level or type of risk, concentrations below the benchmarks should not result in significant effects. In practice, when contaminant concentrations in food or water resources are less than these toxicological benchmarks, these contaminants may be excluded from further consideration. If, however, the concentration of a contaminant exceeds a benchmark, the contaminant should be retained as a contaminant of concern (COC) and be subject to further investigation.

Toxicological benchmarks may also be used as part of a weight-of-evidence approach (Suter, 1992) in a baseline ecological risk assessment, the second tier in ecological risk assessment. Under this approach, toxicological benchmarks are one of several lines of evidence used to support or refute the presence of ecological effects. Other sources of evidence include media toxicity tests, surveys of biota (abundance and diversity), measures of contaminant body burdens, and biomarkers.

This report presents toxicological benchmarks for assessment of effects of 55 chemicals on six representative mammalian wildlife species (short-tailed shrew, white-footed mouse, cottontail rabbit, mink, red fox, and whitetail deer) and eight avian wildlife species (American robin, woodcock, wild turkey, belted kingfisher, great blue heron, barred owl, Cooper's hawk, and redtailed hawk) (scientific names are presented in Appendix C). These species were chosen because they are widely distributed and provide a representative range of body sizes and diets. The chemicals are some of those that occur at United States Department of Energy (DOE) waste sites. The benchmarks presented in this report are values believed to be nonhazardous for the listed wildlife species.

\section{AVAILABILITY AND LIMITATIONS OF TOXICITY DATA}

Information on the toxicity of environmental contaminants to terrestrial wildlife can be obtained from several sources including the United States Environmental Protection Agency (EPA) Terrestrial Toxicity Data Base (TERRE-TOX, see Meyers and Schiller, 1985); U. S. Fish and Wildlife Service reports, EPA assessment and criteria documents, and Public Health Service toxicity profiles. Selected data from these sources are presented in tabular form in Appendix A. Pesticides were excluded from this compilation except for those considered to be likely contaminants on DOE reservations. Most of the available information on the effects of environmental contaminants on wildlife pertains to pesticides and little to industrial and laboratory chemicals of concern to DOE. Furthermore, the toxicity data that are available are often limited to severe effects of acute exposures [e.g., frank-effects levels (FELs), or concentration or dose levels causing $50 \%$ mortality to a test population $\left(\mathrm{LC}_{50}\right.$ and $\left.\left.\mathrm{LD}_{50}\right)\right]$. Few studies have determined maximum safe exposure levels (no-observed-adverse-effect-levels, or NOAELs) for situations in which wildlife have been exposed over ar. entire lifetime or over several generations. [In this document, NOAEL refers to both dose (mg contaminant per $\mathrm{kg}$ animal body weight per day) and concentration (mg contaminant per $\mathrm{kg}$ or $\mathrm{L}$ of food or water).] Consequently, for nearly all wildlife species, a NOAEL for chronic exposures to a particular chemical must be estimated from 
less than ideal data (e.g., $L D_{s 0}$ values) or from toxicity studies of the same chemical conducted on a different species of wildlife or on domestic or laboratory animals. In most cases, the only available information is from studies on laboratory animals (primarily rats and mice). Such laboratory studies represent a database whose use should be maximized; however, individual studies may be somewhat limited in scope and relevance to wildlife.

Wildlife NOAELs that are estimated from data on laboratory animals must be evaluated carefully, bearing in mind the possible limitations of the data. Studies on one particular group of animals, such as mice, may not be appropriate for evaluating potential toxicity to birds, amphibians, or even to other groups of mammals such as deer. Variations may also exist among species within the same family or genus. The reason is that significant physiological or biochemical differences may exist, such as in metabolism and disposition, which can alter the potential toxicity of the chemical in the tested species. Extrapolation of data from laboratory species to wildlife species may also be inappropriate if the inbred laboratory strains have an unusual sensitivity or resistance to the test compound. Differences in behavioral and ecological parameters (e.g., stress factors such as competition, seasonal changes in temperature or food availability, diseased states, or exposure to other contaminants) may make a wildlife species' sensitivity to an environmental contaminant different from that of a laboratory or domestic species.

Available studies on wildlife or laboratory species may not include evaluations of all significant endpoints for determining long-term effects on natural populations. Important data that may be lacking are potential eftects on reproduction, development, and population dynamics following multigeneration exposures.

The available data may identify only the lowest-observed-adverse-effect-level (LOAEL), or an FEL, or $\mathrm{LD}_{50}$. Estimating a NOAEL for a chronic exposure from such data can introduce uncertainty into the calculation.

If the NOAEL (or LOAEL) is based on a study in which the exposure period was subchronic (i.e., from several weeks to several months), then some uncertainty would be associated with estimating at what lower dose level the same effect might occur if the exposure occurred over an entire lifetime or for several generations.

The fewer the number of steps in the extrapolation process the lower the uncertainty in estimating the wildlife NOAEL. For example, extrapolating from a NOAEL for an appropriate toxic endpoint (i.e., reproductive or population effects) for white laboratory mice to white-footed mice that are relatively closely related and are of comparable body size would have a high level of reliability. Extrapolating from a LOAEL or FEL for a less ideal endpoint (i.e., change in enzyme activity) in laboratory mice to a non-rodent wildlife species would have a low level of reliability in predicting actual effects on natural populations. Extrapolation models for these wildlife extrapolations have not been developed as they have for aquatic biota (Suter, 1992).

\section{METHODOLOGY}

The general method to be used for these extrapolations is one based on an EPA methodology for deriving human toxicity values (e.g., Reference Values, Reportable Quantities, and unit risks for carcinogenicity) from animal data (EPA, 1986a, 1986b, 1988, 1989). 
The first step in the procedure is to identify the toxicity data currently available for the chemicals of interest. NOAELs and LOAELs for the chemicals of concern at DOE facilities were obtained from the open literature, EPA review documents, and secondary sources Registry of Toxic Effects of Chemical Substances (RTECs) (Appendix B). NOAELs and LOAELs are daily dose levels normalized to the body weight of the test animals (e.g., milligrams of chemical per kilogram body weight per day). The presentation of toxicity data on a $\mathrm{mg} / \mathrm{kg} /$ day basis allows comparisons across tests and across species with appropriate consideration for differences in body size. Studies have shown that numerous physiological functions such as metabolic rates, as well as responses to toxic chemicals, are a function of body size. Smaller animals have higher metabolic rates and are usually more resistant to toxic chemicals because of more rapid rates of detoxification (however, this may not be the case if the toxic effects of the compound are produced primarily by a metabolite). It has been shown that the best measure of differences in body size are those based on body surface area which, for lack of direct measurements, can be expressed in terms of body weight (bw) raised to the $2 / 3$ power $\left(b^{2 / 3}\right)$ (EPA, 1980). If the dose (d) itself has been calculated in terms of unit body weight (i.e., $\mathrm{mg} / \mathrm{kg}$ ), then the dose per unit surface area (D) equates to

$$
D=\frac{d x b w}{b w^{2 / 3}}=d \times b w^{1 / 3}
$$

The assumption is that the dose per body surface area (Equation 1) for species "a" and "b" would be equivalent:

$$
d_{a} \times b w_{a}^{1 / 3}=d_{b} \times b w_{b}^{1 / 3}
$$

Therefore, knowing the body weights of two species and the dose $\left(d_{b}\right)$ producing a given effect in species "b," the dose $\left(d_{a}\right)$ producing the same effect in species "a" can be determined:

$$
d_{a}=d_{b} \times \frac{b w_{i}{ }^{13}}{b w_{a}^{1 / 3}}=d_{b} \times\left(b w_{b} / b w_{a}\right)^{1 / 3}
$$

This is the methodology that EPA uses in carcinogenicity assessments and reportable quantity documents for adjusting from animal data to an equivalent human dose (EPA, 1985, 1988). The same approach has been proposed for use in extrapolating from one animal species to another. However, it should be noted that this method has not been applied to wildlife by the EPA and that wildlife toxicologists commonly scale dose to body weight without incorporating the exponential factor of $2 / 3$. The exponent has been retained for this report because no reason exists why different methods should be used to extrapolate from mice to humans and mice to foxes. The issue of appropriate scaling models for wildlife should be investigated.

For developing reference doses (RfDs), EPA uses a default factor of 0.1 to adjust an animal dose to an equivalent human dose. Using the body size scaling method outlined above results in an adjustment factor of about 0.07 when deriving an equivalent human dose from data for mice (using the standard body weight of $0.03 \mathrm{~kg}$ for mice and $70 \mathrm{~kg}$ for humans) and a factor of about 0.17 when deriving an equivalent human dose from data on rats (standard body weight $0.35 \mathrm{~kg}$ ).

The ideal data set to use in the calculation would be the actual average body weights of the test animals used in the bioassay. When this information is not available, standard reference body 
weights for laboratory species can be used as indicated above (EPA, 1986). Body weight data for wildlife species are available from several secondary sources [i.e., the Mammalian Species series, published by the American Society of Mammalogists and Whitaker (1980) (see Appendix C)]. Often, only a range of adult body weight values is available for a species, in which case an average value must be estimated. A time-weighted average body weight for the entire life span of a species would be the most appropriate data set to use for chronic exposure situations; however, such data are usually not available. Because body weights of a species can vary geographically as well as by sex, population and/or sex-specific data may be appropriate for assessments of some chemicals. Unless otherwise stated, weight data represent means for both sexes and individuals from throughout the species geographic range.

If a NOAEL is available for the test species (NOAEL), then the equivalent NOAEL for a species of wildlife (NOAEL $\mathrm{N}_{w}$ ) can be calculated by using the adjustment factor for differences in body size:

$$
\operatorname{NOAEL}_{w}=\text { NOAEL }_{\mathrm{t}} \times\left(\mathrm{bw} / \mathrm{bw} \mathrm{w}_{\mathrm{w}}\right)^{1 / 3}
$$

The dietary level or concettration in food $\left(\mathrm{C}_{f}\right.$, in $\mathrm{mg} / \mathrm{kg}$ food) which would result in a dose equivalent to the NOAEL (assuming no other exposure through other environmental media) can be calculated from the food factor $f$, which is the amount of food consumed per unit body weight per day:

$$
\mathrm{C}_{\mathrm{f}}=\frac{\text { NOAEL }_{\mathrm{w}}}{f}
$$

For laboratory mice, rats, and dogs, $f$ values are $0.13,0.05$, and 0.025 , respectively (EPA, 1980, 1985). Food factors for wildlife species are generally not available. In such cases, the food factor for the most closely related laboratory or domestic species can be used, or it can be derived from the rate of food consumption ( $\mathrm{F}$, in $\mathrm{g} / \mathrm{day}$ or $\mathrm{kg} / \mathrm{day}$ ) and the body weight (bw, in $\mathbf{g}$ or $\mathbf{~} \mathrm{g}$ ):

$$
f=\frac{\mathrm{F}}{\mathrm{bw}}
$$

Rates of food consumption (F) for laboratory mammals can be estimated from allometric regression models derived from experimental data (EPA, 1987):

$$
\begin{aligned}
& F=0.054(\mathrm{bw})^{0.9451} \text { (moist diet) } \\
& F=0.049(\mathrm{bw})^{0.0089}(\text { dry diet) }
\end{aligned}
$$

where $\mathrm{F}$ is the food consumed in $\mathrm{kg} /$ day, and bw is the body weight in $\mathrm{kg}$.

Food consumption rates for wildlife can be estimated from allometric regression models based on metabolic rate (Nagy, 1987):

$$
\begin{aligned}
& F=0.235(\mathrm{bw})^{0.02} \text { (placental mammals) } \\
& F=0.621(\mathrm{bw})^{0.564} \text { (rodents) }
\end{aligned}
$$




$$
\begin{aligned}
& F=0.577(\mathrm{bw})^{0.27} \text { (herbivores) } \\
& F=0.492(\mathrm{bw})^{0.673}(\text { marsupials) } \\
& F=0.648(\mathrm{bw})^{0.651}(\mathrm{birds}) \\
& F=0.398(\mathrm{bw})^{0.850} \text { (passerine birds) }
\end{aligned}
$$

where $\mathrm{F}$ is food consumed in $\mathrm{g} / \mathrm{day}$, and bw is the body weight in $\mathrm{g}$.

The concentration of the contaminant in the drinking water of an animal $\left(\mathrm{C}_{w}\right.$, in $\left.\mathrm{mg} / \mathrm{L}\right)$ resulting in a dose equivalent to a NOAEL ${ }_{w}$ can be calculated from the daily water consumption rate $(\mathrm{W}$, in $\mathrm{L} / \mathrm{day})$ and the average body weight $\left(\mathrm{bw}_{\mathrm{w}}\right)$ for t'.le species:

$$
C_{w}=\frac{\text { NOAEL }_{w} \times \text { bw }_{w}}{W}
$$

The rate of water consumption per unit body weight $(\mathrm{W} / \mathrm{bw})$ is termed the water factor $\omega$ and can be used in a manner identical to that for the food factor.

If a wildlife species (such as mink or otter) feeds primarily on aquatic organisms, and the concentration of the contaminant in the food is proportional to the concentration in the water, then the food consumption rate (F, in $\mathrm{kg} / \mathrm{day}$ ) and the aquatic life bioaccumulation factor [BAF, the ratio $(\mathrm{L} / \mathrm{kg})$ of the concentration in tissue to its concentration in water, where both the organism and its prey are exposed] can be used to derive a final $C_{w}$ value (EPA, 1993):

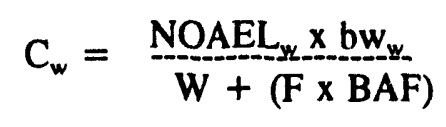

Bioaccumulation factors may be predicted by multiplying the bioconcentration factor for the contaminant $[B C F$, ratio of concentration in food to concentration in water, $(\mathrm{mg} / \mathrm{kg}) /(\mathrm{mg} / \mathrm{L})=$ $\mathrm{L} / \mathrm{kg}$ ] by the appropriate food chain multiplying factor (FCM). For most inorganic compounds, BCFs and BAFs are assumed to equal; however, an FCM may be applicable for some metals if the organometallic form biomagnifies (EPA, 1993).

For laboratory mice, rats, and dogs, reference water consumption values are $0.0057,0.049$, and $0.61 \mathrm{~L} /$ day, respectively (EPA, 1986). Water consumption values for wildlife species are generally not available. In such cases, values for the most closely related laboratory or domestic species may be used in the calculation, or the rate of water consumption can be estimated from allometric regression models derived from experimental data for laboratory mammals (EPA, 1987):

$$
\begin{aligned}
& W=0.090(\mathrm{bw})^{1.2044}(\text { mammals, moist diet) } \\
& W=0.093(\mathrm{bw})^{0.7584} \text { (mammals, dry diet) }
\end{aligned}
$$

where $\mathrm{W}$ is the water consumed in L/day, and bw is the body weight in $\mathrm{kg}$. 
The rate of water consumption can be estimated form allometric regression models derived from experimental data for mammalian wildlife :

$$
\mathrm{W}=0.099(\mathrm{bw})^{0.90}
$$

where $\mathrm{W}$ is the water consumed in L/day, and bw is the body weight in $\mathrm{kg}$ (Calder and Braun, 1983). A similar model has also been developed for birds (Calder and Braun, 1983):

$$
\mathrm{W}=0.059(\mathrm{bw})^{0.67}
$$

In cases where a NOAEL for a specific chemical is not available for either wildlife or laboratory species, but a LOAEL has been determined experimentally, the NOAEL can be estimated by applying an uncertainty factor (UF) to the LOAEL. In the EPA methodology, the LOAEL can be reduced by a factor of up to 10 to derive the NOAEL.

$$
\text { NOAEL }=\frac{\text { LOAEL }}{\leq 10}
$$

Although a factor of 10 is usually used in the calculation, the true NOAEL may be only slightly lower than the experimental LOAEL, particularly if the observed effect is of low severity. A thorough analysis of the available data for the dose-response function may reveal whether a LOAEL to NOAEL uncertainty factor of $<10$ should be used.

If the only available data consist of a NOAEL (or a LOAEL) for a subchronic exposure of several weeks to several months or more, then the equivalent NOAEL or LOAEL for a chronic exposure can be estimated by applying another UF to the data. In the EPA methodology, a factor of up to 10 can be used:

$$
\text { chronic NOAEL }=\frac{\text { subchronic NOAEL }}{\leq 10}
$$

As in the case of the LOAEL to NOAEL adjustment, a factor of 10 is usually used in the calculation; however, other evidence, such as that for a related compound using the same toxicity endpoint, may suggest that an adjustment factor of $<10$ is more appropriate. No data were found for any of the contaminants considered thereby suggesting the use of a LOAEL-NOAEL adjustment factor of $<10$.

If the available data are limited to acute toxicity endpoints (FEL, frank-effects level) or to exposure levels associated with lethal effects $\left(L D_{50} s\right)$, the estimation of NOAELs for chronic exposures are likely to have a wide margin of error because no standardized mathematical exists correlation between FEL or $\mathrm{LD}_{s_{0}}$ dose levels and NOAELs which can routinely be applied to all chemicals (exposure levels associated with NOAELs may range from $1 / 10$ to $1 / 10,000$ of the acutely toxic dose, depending on the chemical and species). However, if sufficient data exist for a related chemical $a$ (i.e., if both an $\mathrm{LD}_{50}$ and a NOAEL have been determined), then this ratio should be used to estimate a NOAEL $L_{w}$ from the $\left(\mathrm{LD}_{s_{0}}\right)_{w}$ for the compound of interest. 


$$
\mathrm{NOAEL}_{\mathrm{w}}=\left(\mathrm{LD}_{\mathrm{s0}}\right)_{\mathrm{w}} \frac{\mathrm{NOAEL}_{a_{-}}}{\left(\mathrm{LD}_{\mathrm{so}}\right)_{a}}
$$

\section{APPLICATION OF THE METHODOLOGY}

Two examples will be given illustrating the application of the extrapolation methodology for deriving NOAELs and environmental criteria for food and water. In one example (inorganic trivalent arsenic), the estimated values were derived primarily from data on laboratory species. In the second example [Aroclor 1254, a polychlorinated biphenyl (PCB) formulation], experimental data were available for two species of wildlife.

\subsection{INORGANIC TRIVALENT ARSENIC}

The toxicity of inorganic compounds containing arsenic depends on the valence or oxidation state of the arsenic as well as on the physical and chemical properties of the compound in which it occurs. Trivalent $\left(\mathrm{As}^{+3}\right)$ compounds such as arsenic trioxide $\left(\mathrm{As}_{2} \mathrm{O}_{3}\right)$, arsenic trisulfide $\left(\mathrm{As}_{2} \mathrm{~S}_{3}\right)$, and sodium arsenite $\left(\mathrm{NaAsO}_{2}\right)$, are generally more toxic than pentavalent $\left(\mathrm{As}^{+5}\right)$ compounds such as arsenic pentoxide $\left(\mathrm{As}_{2} \mathrm{O}_{5}\right)$, sodium arsenate $\left(\mathrm{Na}_{2} \mathrm{HAsO}_{4}\right)$, and calcium arsenate $\left[\mathrm{Ca}_{3}\left(\mathrm{AsO}_{4}\right)_{2}\right]$. The relative toxicity of the trivalent and pentavalent forms may also be affected by factors such as water solubility; the more toxic compounds are generally more water soluble. In this analysis, the effects of the trivalent form of arsenic in water soluble inorganic compounds will be evaluated. In many cases, only total arsenic concentrations are reported so the assessor must conservatively assume that it is all trivalent.

\subsubsection{Toxicity to Wildlife}

The only wildlife toxicity information available for trivalent inorganic arsenic compounds pertains to acute exposures (Table 1; the data points listed are those reported in the literature).

\begin{tabular}{|c|c|c|c|c|c|}
\hline Species & Chemical & $\begin{array}{l}\text { Conc. in Diet } \\
(\mathrm{mg} / \mathrm{kg} \text { food) }\end{array}$ & $\begin{array}{c}\text { Dose } \\
(\mathrm{mg} / \mathrm{kg})\end{array}$ & Efrect & Reference \\
\hline $\begin{array}{l}\text { Whitetail deer } \\
\text { (Odocoileus virginianus) }\end{array}$ & $\begin{array}{l}\text { sodium } \\
\text { arsenite }\end{array}$ & NR & 34 & Lethal dose & NAS, 1977 \\
\hline \multirow[t]{2}{*}{$\begin{array}{l}\text { Mallard duck } \\
\text { (Anas platyrhynchos) }\end{array}$} & $\begin{array}{l}\text { sodium } \\
\text { arsenite }\end{array}$ & NR & $\begin{array}{c}323 \\
\text { (single dose) }\end{array}$ & $L_{\text {so }}$ & NAS, 1977 \\
\hline & $\begin{array}{l}\text { sodium } \\
\text { arsenite }\end{array}$ & 500 & NR & 32-day $L D_{s 0}$ & NAS, 1977 \\
\hline $\begin{array}{l}\text { California quail } \\
\text { (Callipepla califormica) }\end{array}$ & $\begin{array}{l}\text { sodium } \\
\text { arsenite }\end{array}$ & NR & 47.6 & $\mathrm{LD}_{s 0}$ & $\begin{array}{l}\text { Hudson et al., } \\
1984\end{array}$ \\
\hline $\begin{array}{l}\text { Ring-necked pheasant } \\
\text { (Phasianus colchicus) }\end{array}$ & $\begin{array}{l}\text { sodium } \\
\text { arsenite }\end{array}$ & NR & $\begin{array}{c}386 \\
\text { (single dose) }\end{array}$ & $\mathrm{LD}_{\text {so }}$ & $\begin{array}{l}\text { Hudson et al., } \\
1984\end{array}$ \\
\hline
\end{tabular}

' Source of data and references: Eisler, 1988.

NR. Not reported. 
For whitetail deer, the estimated lethal dose is $34 \mathrm{mg}$ sodium arsenite $/ \mathrm{kg}$ or $19.5 \mathrm{mg} \mathrm{As} / \mathrm{kg}$ (NAS, 1977). For birds, estimated $L D_{s 0}$ values for sodium arsenite range from 47.6 to $386 \mathrm{mg} / \mathrm{kg}$ body weight. Median lethality was also reported at a dietary level of $500 \mathrm{mg} / \mathrm{kg}$ food for mallard ducks. No information was found regarding chronic toxicity or reproductive or developmental effects. No chronic NOAELs or LOAELs are available; therefore, data on domestic or laboratory species must be used to identify NOAELs for wildlife.

\subsubsection{Toxicity to Domestic Animais}

Summary of toxicity of inorganic trivalent arsenic to domestic animals is summarized in Table 2 (data listed as given in the literature sources). For assessment purposes, the most useful study is the one identifying a NOAEL of $1.25 \mathrm{mg} \mathrm{As} / \mathrm{kg} / \mathrm{day}$ in dogs following a chronic (2 year) dietary exposure to sodium arsenite.

\begin{tabular}{|c|c|c|c|c|c|}
\hline Species & Chemical & $\begin{array}{l}\text { Conc. in Diet } \\
\text { or Water }\end{array}$ & Dose $^{d}$ & Effect & Reference \\
\hline \multicolumn{6}{|c|}{ MAMMALS: } \\
\hline \multirow[t]{2}{*}{ Cattle } & arsenic trioxide & NR & $\begin{array}{l}33-55 \mathrm{mg} / \mathrm{kg} \\
\text { (single dose) }\end{array}$ & toxic & $\begin{array}{l}\text { Robertson } \\
\text { et al., } 1984\end{array}$ \\
\hline & sodium arsenite & NR & $1-4 \mathrm{~g} /$ animal & lethal & NRCC, 1978 \\
\hline \multirow[t]{2}{*}{ Sheep } & sodium arsenite & NR & $\begin{array}{l}5-12 \mathrm{mg} / \mathrm{kg} \\
\text { (single dose) }\end{array}$ & acutely toxic & NRCC, 1978 \\
\hline & "total arsenic" & $\begin{array}{l}58 \mathrm{mg} \mathrm{As} / \mathrm{kg} \text { food } \\
(3 \mathrm{wk})\end{array}$ & NR & $\begin{array}{l}\text { no adverse } \\
\text { effects }\end{array}$ & Woolson, 1975 \\
\hline Horse & sodium arsenite & NR & $\begin{array}{l}2-6 \mathrm{mg} / \mathrm{kg} / \text { day } \\
(14 \mathrm{wk})\end{array}$ & lethal & NRCC, 1978 \\
\hline Pig & sodium arsenite & $500 \mathrm{mg} \mathrm{As} / \mathrm{L}$ & $100-200 \mathrm{mg} / \mathrm{kg}$ & lethal & NAS, 1977 \\
\hline Cat & arsenite & NR & $1.5 \mathrm{mg} / \mathrm{kg} / \mathrm{day}$ & $\begin{array}{l}\text { chronic toxic } \\
\text { effects }\end{array}$ & $\begin{array}{l}\text { Pershagen and } \\
\text { Vahter, } 1979 \\
\end{array}$ \\
\hline \multirow[t]{4}{*}{ Dog } & sodium arsenite & NR & $\begin{array}{l}50-150 \\
\text { mg/animal }\end{array}$ & lethal & NRC, 1978 \\
\hline & sodium arsenite & $\begin{array}{l}125 \mathrm{mg} \mathrm{As} / \mathrm{kg} \\
\text { food (2 year) }\end{array}$ & $\begin{array}{l}3.1 \mathrm{mg} \\
\mathrm{As} / \mathrm{kg} / \mathrm{day}\end{array}$ & $\begin{array}{l}\text { reduced } \\
\text { survival }\end{array}$ & $\begin{array}{l}\text { Byron et al., } \\
1967\end{array}$ \\
\hline & sodium arsenite & $\begin{array}{l}50 \mathrm{mg} \mathrm{As} / \mathrm{kg} \text { food } \\
\text { (2 year) }\end{array}$ & $\begin{array}{l}1.25 \mathrm{mg} \\
\mathrm{As} / \mathrm{kg} / \mathrm{day}\end{array}$ & NOAEL & $\begin{array}{l}\text { Byron et al., } \\
1967\end{array}$ \\
\hline & sodium arsenite & NR & $\begin{array}{l}4 \mathrm{mg} / \mathrm{kg} / \mathrm{day} \\
(58 \mathrm{days}) \\
+8 \mathrm{mg} / \mathrm{kg} \\
(125 \text { days }) \\
\end{array}$ & $\begin{array}{l}\text { LOAEL; } \\
\text { liver enzyme } \\
\text { changes }\end{array}$ & $\begin{array}{l}\text { Neiger and } \\
\text { Osweiler, } 1989\end{array}$ \\
\hline Mammals & arsenic trioxide & NR & $3-250 \mathrm{mg} / \mathrm{kg}$ & lethal & NAS, 1977 \\
\hline Mammals & sodium arsenite & NR & $1-25 \mathrm{mg} / \mathrm{kg}$ & lethal & NAS, 1977 \\
\hline
\end{tabular}




\begin{tabular}{|c|c|c|c|c|c|}
\hline Species & Chemical & $\begin{array}{c}\text { Conc. in Diet } \\
\text { or Water }\end{array}$ & Dose $^{d}$ & Effect & Reference \\
\hline \multicolumn{6}{|l|}{ BIRDS: } \\
\hline \multirow{2}{*}{$\begin{array}{l}\text { Chicken } \\
\text { (Gallus } \\
\text { gallus) }\end{array}$} & arsenite & NR & $\begin{array}{l}0.01-1.0 \mu \mathrm{g} \\
\text { As/embryo }\end{array}$ & $\leq 34 \%$ dead & NRCC, 1978 \\
\hline & arsenite & NR & $\begin{array}{l}0.03-0.3 \mu \mathrm{g} \\
\text { As/embryo }\end{array}$ & $\begin{array}{l}\text { threshold for } \\
\text { malformation } \\
\text { s }\end{array}$ & NRCC, 1978 \\
\hline
\end{tabular}

- Sources of data and references: USAF, 1990; Eisler, $1988 . \quad$ NR Not reportod.

- Dietary level given as $\mathrm{mg} / \mathrm{kg}_{\mathrm{g}}$ food.

- Concentration in water given as mg/L.

- Dose refers to compound unless otherwise stated.

\subsubsection{Toxicity to Laboratory Animals (Rodents)}

Selected acute and chronic toxicity data for trivalent arsenic in rats and mice are summarized in Table 3 (dietary or drinking water concentrations were converted to daily dose levels as discussed earlier or from more specific information given in the original source). For environmental assessment purposes, the most useful toxicity values reported are the NOAELs of 0.7 and $2.44 \mathrm{mg} \mathrm{As} / \mathrm{kg} /$ day reported for rats and the LOAEL of $0.38 \mathrm{mg} \mathrm{As} / \mathrm{kg} /$ day for reproductive effects (decreased litter size) in mice exposed for three generations. The reported value of $4.88 \mathrm{mg} \mathrm{As} / \mathrm{kg}$ can also be considered a NOAEL for population effects in rats, since the only observed adverse effect was a slight reduction in growth of females.

\begin{tabular}{|c|c|c|c|c|c|}
\hline Species & Chemical & $\begin{array}{l}\text { Conc. in Diet" } \\
\text { or Water }\end{array}$ & $\begin{array}{c}\text { Dose } \\
\text { (mg As/kg) }\end{array}$ & Efrect & Reference \\
\hline \multirow[t]{5}{*}{ Rat } & arsenic trioxide & NR & 15.1 (1 dose) & $L D_{s 0}$ & Harrison et al., 1958 \\
\hline & sodium arsenite & $\begin{array}{l}125 \mathrm{mg} \mathrm{As} / \mathrm{kg} \text { food } \\
(2 \text { year) }\end{array}$ & 9.75 & $\begin{array}{l}\text { FEL, bile duct } \\
\text { enlargement }\end{array}$ & Byron et al., 1967 \\
\hline & sodium arsenite & $\begin{array}{l}62.5 \mathrm{mg} \mathrm{As} / \mathrm{kg} \text { food } \\
(2 \text { year) }\end{array}$ & 4.88 & $\begin{array}{l}\text { reduced growth in } \\
\text { females; no effect on } \\
\text { survival }\end{array}$ & Byron et al., 1967 \\
\hline & sodium arsenite & $\begin{array}{l}31.25 \mathrm{mg} \mathrm{As} / \mathrm{kg} \\
\text { food (2 year) }\end{array}$ & 2.44 & NOAEL & Byron et al., 1967 \\
\hline & sodium arsenite & $\begin{array}{l}5 \mathrm{mg} \mathrm{As} / \mathrm{L} \\
\text { (lifetime) }\end{array}$ & 0.7 & NOAEL & $\begin{array}{l}\text { Schroeder et al., } \\
1968\end{array}$ \\
\hline \multirow[t]{2}{*}{ Mouse } & arsenic trioxide & NR & 39.4 (1 dose) & $L D_{s 0}$ & Harrison et al., 1958 \\
\hline & sodium arsenite & NR & $\begin{array}{l}\text { a. } 23 \text { (1 dose }) \\
\text { b. } 11.5 \text { (1 dose) }\end{array}$ & $\begin{array}{l}\text { a. Fetal mortality } \\
\text { b. NOAEL }\end{array}$ & Baxley et al., 1981 \\
\hline
\end{tabular}




\begin{tabular}{|c|c|c|c|c|c|}
\hline Species & Chemical & $\begin{array}{l}\text { Conc. in Diet" } \\
\text { or Water }\end{array}$ & $\begin{array}{c}\text { Dose } \\
\text { (mg As/kg) }\end{array}$ & Efrect & Reference \\
\hline & arsenic trioxide & $\begin{array}{l}75.8 \mathrm{mg} \mathrm{As} / \mathrm{L} \\
\text { (lifetime) }\end{array}$ & 21.6 & $\begin{array}{l}\text { LOAEL; mild } \\
\text { hyperkeratosis/epi- } \\
\text { dermal hyperplasia }\end{array}$ & Baroni et al., 1963 \\
\hline & soluble arsenite & $\begin{array}{l}5 \mathrm{mg} \mathrm{As} / \mathrm{L}+ \\
0.06 \mathrm{mg} \mathrm{As} / \mathrm{kg} \text { food } \\
(3 \text { generations) }\end{array}$ & $\begin{array}{l}0.38^{c} \\
0.95^{d}\end{array}$ & $\begin{array}{l}\text { LOAEL; incr. in } \\
\text { male to female ratio; } \\
\text { decr. in litter size }\end{array}$ & $\begin{array}{l}\text { Schroeder and } \\
\text { Mitchener, } 1971\end{array}$ \\
\hline & sodium arsenite & $\begin{array}{l}5 \mathrm{mg} \mathrm{As} / \mathrm{L}+ \\
0.46 \mathrm{mg} \mathrm{As} / \mathrm{kg} \text { food } \\
\text { (lifetime) }\end{array}$ & $0.38^{c}$ & $\begin{array}{l}\text { LOAEL; slight decr. } \\
\text { in median life span; } \\
\text { no effect on growth }\end{array}$ & $\begin{array}{l}\text { Schroeder and } \\
\text { Balassa, } 1967\end{array}$ \\
\hline & sodium arsenite & $\begin{array}{l}0.5 \mathrm{mg} \mathrm{As} / \mathrm{L} \\
(3 \text { weeks })\end{array}$ & 0.10 & $\begin{array}{l}\text { LOAEL; } \\
\text { immunosuppressive } \\
\text { effects }\end{array}$ & Blakely et al., 1980 \\
\hline
\end{tabular}

Dietary level in mg/kg food.

- Concentration in water given as $\mathrm{mg} / \mathrm{L}$.

- As estimated by Schroeder and Balassa, 1967.

- As estimated from the concentration in water, a water consumption of $0.0057 \mathrm{~L}$ day, and a standard reference body weight of 0.03 (Equations 15).

\subsubsection{Extrapolations to Wildlife Species}

Extrapolated toxicity values for trivalent arsenic for representative wildlife species are shown in Table 4 based on selected data from Tables 2 and 3. The values for the concentration in food $\left(C_{f}\right)$ represent maximum acceptable concentrations assuming no additional exposure through water consumption. Similarly, the concentration in water $\left(\mathrm{C}_{\mathrm{w}}\right)$ is the maximum acceptable concentration assuming no additional exposure through dietary intake. If dietary and water intake contributed equally to the exposure, and absorption rates through the GI tract were similar, then the equivalent dietary level and water concentration would be one-half of the listed values. Exposures through inhalation or direct dermal contact are not taken into consideration in these calculations. If these other exposure routes are significant, then the maximum acceptable $C_{r}$ and $\mathrm{C}_{\mathrm{w}}$ must be adjusted accordingly.

The NOAEL value listed for the white-footed mouse is derived from the experimental LOAEL for laboratory mice. Two values are given for the LOAEL: $0.95 \mathrm{mg} / \mathrm{kg}$ is based on the standard EPA water consumption rate for mice $(0.0057 \mathrm{~L} /$ day), and $0.38 \mathrm{mg} / \mathrm{kg}$ is the dose estimate based on a water intake of $6 \mathrm{~mL} / 100 \mathrm{~g}$ bw which was calculated by Schroeder and Balassa (1967) in a related study using the same exposure protocol. A range of values is given for the NOAEL for laboratory mice because there is the uncertainty as to whether the true NOAEL is only slightly below the experimental LOAEL or as much as 1/10 of the lowest reported LOAEL (the EPA default value as given in Equation 21). The NOAEL for the whitefooted mouse is derived from Equation 4 which adjusts the values for differences in body size. Because the body weights of the two species are similar, the range in the NOAELs is almost identical.

Also using Equation 4, the NOAEL for the cotton rat is derived from the NOAEL for the laboratory rat, and that for the red fox from the NOAEL for the dog. All four values are greater than the NOAEL for the laboratory mouse whereas the body size differences alone would suggest that the mice should have the higher NOAEL. There can be several explanations for these 
differences. Mice may be unusually sensitive to trivalent arsenic; however, the $L_{s_{0}}$ data for rats and mice do not support this conclusion. The mouse data were derived from a three-generation bioassay in which reproductive effects (reduced litter size) were identified. Conversely, the rat study consisted of a lifetime exposure, while the dog study was for only 2 years; reproductive effects were not evaluated for rats or dogs. Therefore, it is possible that reproductive effects similar to those seen in mice might occur in rats and dogs at or below the listed NOAELs if multigeneration studies were conducted.

The calculations given in Table 4 for the NOAEL for whitetail deer illustrate the problems that can arise if data for different species are used in the extrapolation procedure. The estimated NOAELS (from Equation 4) for whitetail deer are $\geq 0.003<0.008 \mathrm{mg} / \mathrm{kg}$ as derived from the range of estimated mouse NOAELS, $0.81 \mathrm{mg} / \mathrm{kg}$ as derived from the rat data, and $0.74 \mathrm{mg} / \mathrm{kg}$ as derived from the dog data. These values convert to dietary levels of $\geq 0.10<0.26 \mathrm{mg} / \mathrm{kg}$ food, $27.9 \mathrm{mg} / \mathrm{kg}$ food and $25.5 \mathrm{mg} / \mathrm{kg}$ food, respectively. A dietary NOAEL of $5.8 \mathrm{mg} / \mathrm{kg}$ food (total arsenic) for sheep (derived from a NOAEL of $58 \mathrm{mg} / \mathrm{kg}$ food for a 3-week exposure by using Equation 23) suggests that the NOAEL for whitetail deer for nonreproductive effects is likely to be close to the values extrapolated from the rat or dog studies. However, the most conservative estimate, based on potential reproductive effects, would be the lowest value extrapolated from the mouse data $(0.003 \mathrm{mg} / \mathrm{kg} /$ day $)$.

\subsection{POLYCHLORINATED BIPHENYLS}

Polychlorinated biphenyls occur in a variety of different formulations consisting of mixtures of individual compounds. The most well-known of these formulations is the Aroclor series (i.e., Aroclor 1016, Aroclor 1242, Aroclor 1248, Aroclor 1254, etc.). The Aroclor formulations vary in the percent chlorine, and, generally, the higher the chlorine content the greater the toxicity. This analysis will focus on Aroclor 1254 for which chronic toxicity data are available for two species of wildlife.

\subsubsection{Toxicity to Wildlife}

Wildlife toxicity test data for Aroclor 1254 is limited to two species-white-footed mice and mink (Table 5). In both species the reproductive system and developing embryos are adversely affected by both acute and chronic exposures. A dietary LOAEL of $10 \mathrm{mg} / \mathrm{kg}$ food $(1.7 \mathrm{mg} / \mathrm{kg} / \mathrm{day})$ was reported for white-footed mice, and a dietary NOAEL of $1 \mathrm{mg} / \mathrm{kg}$ food $(0.07 \mathrm{mg} / \mathrm{kg})$ was reported for mink.

\subsubsection{Toxicity to Domestic Animals}

No information is available on the toxicity of Aroclor 1254 to domestic animals.

\subsubsection{Toxicity to Laboratory Animals}

As shown in Table 6, laboratory studies have identified a dietary NOAEL of $<5 \mathrm{mg} / \mathrm{kg}$ food $(<0.25 \mathrm{mg} / \mathrm{kg} /$ day) for rats exposed to Aroclor 1254 over two generations. Reported LOAELs are 4-10 times higher than the NOAEL, and the single-dose $L^{20}$ is about 4000 -fold higher than the NOAEL. As shown by the dose levels that produce fetotoxicity during gestation, rabbits appear to be less sensitive than rats. 


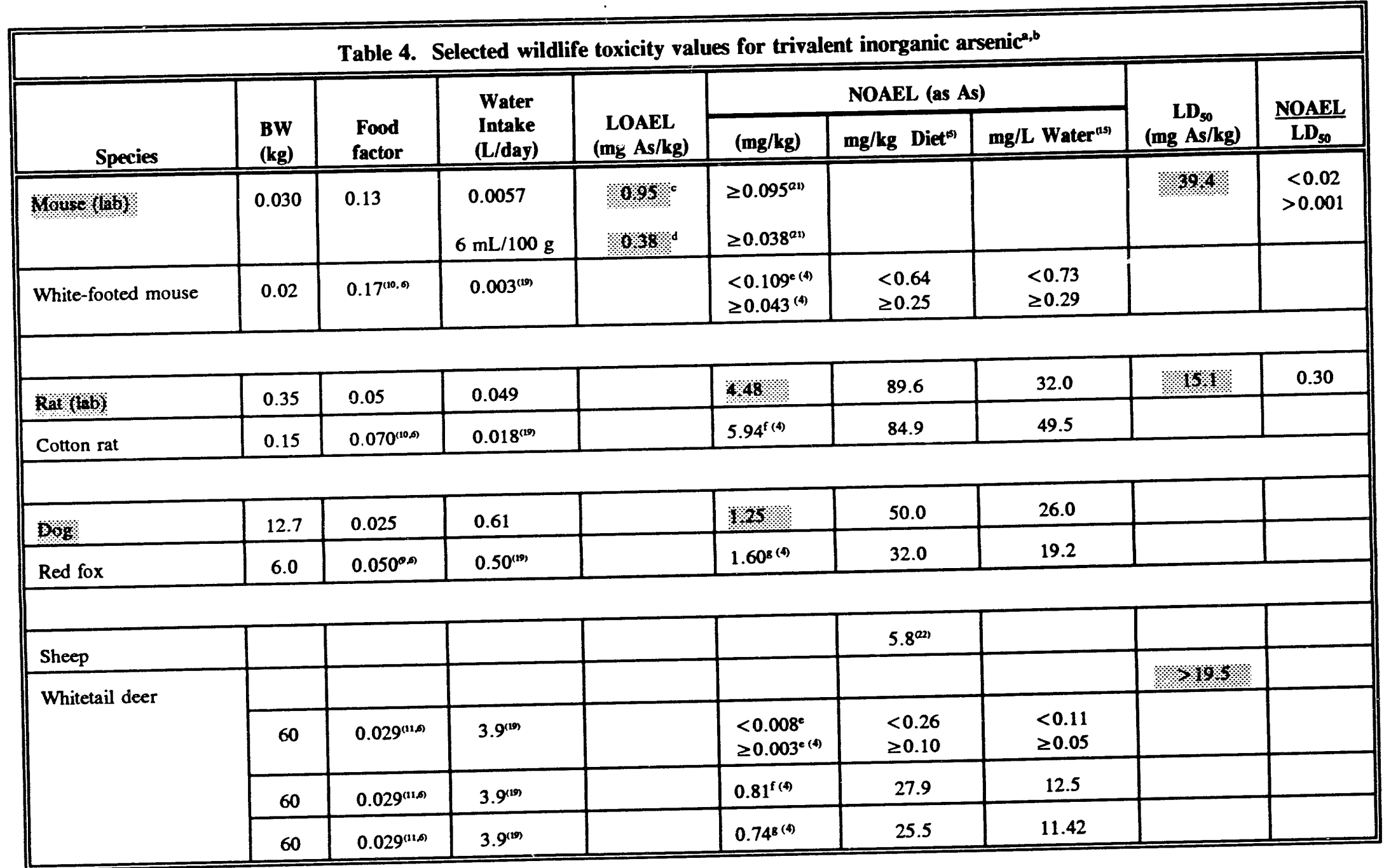

- Numbers in parentheses refer to equations in text used to derive the values.

- Shaded values are experimentally derived.

- Based on EPA water consumption rate for mice.

- Extrapolated from data for laboratory mice.

${ }^{4}$ Based on data given in Schrooder and Balassa, 1967.

'Extrapolated from data for laboratory rat.

- Extrapolated from data for dog. 


\begin{tabular}{|c|c|c|c|c|c|}
\hline Species & Concentration in Diet & $\begin{array}{l}\text { Daily Dose } \\
\text { (mg/kg) }\end{array}$ & $\begin{array}{l}\text { Expos. } \\
\text { Period }\end{array}$ & Eriect & Reference \\
\hline \multicolumn{6}{|l|}{ MAMMAIS: } \\
\hline \multirow[t]{3}{*}{ White-footed mouse } & $400 \mathrm{mg} / \mathrm{kg}_{\mathrm{g}}$ foodt & 68 & $2.3 w k$ & FEL, reprod. & $\begin{array}{l}\text { Sanders and Kirkpatrick. } \\
1975\end{array}$ \\
\hline & $200 \mathrm{mg} / \mathrm{kg}$ food & 34 & $60 d$ & $\begin{array}{l}\text { LOAEl, } \\
\text { reproduction }\end{array}$ & $\begin{array}{l}\text { Merson and Kirkpatrick, } \\
1976\end{array}$ \\
\hline & $10 \mathrm{mg} / \mathrm{kg}$ food" & 1.7 & $18 \mathrm{mo}$ & $\begin{array}{l}\text { LOAEL, } \\
\text { reproduction }\end{array}$ & Linzey, 1987 \\
\hline \multirow[t]{3}{*}{ Mink } & $6.5 \mathrm{mg} / \mathrm{kg}$ food & 1.25 & 9 mo & $L C_{s 0}$ & $\begin{array}{l}\text { Ringer et al., 1981; } \\
\text { ATSDR, 1989a }\end{array}$ \\
\hline & $2 \mathrm{mg} / \mathrm{kg}$ food & $\begin{array}{l}0.38^{b} \\
0.14^{\circ}\end{array}$ & $9 \mathrm{mo}$ & $\begin{array}{l}\text { FEL/LOAEL, } \\
\text { fetotoxicity }\end{array}$ & $\begin{array}{l}\text { Aulerich and Ringer, } \\
1977\end{array}$ \\
\hline & $1 \mathrm{mg} / \mathrm{kg}_{\mathrm{g}}$ food & $0.07^{\circ}$ & 5 mo & NOAEL. & $\begin{array}{l}\text { Aulerich and Ringer, } \\
1977\end{array}$ \\
\hline
\end{tabular}

- Eximeled from Equation 5 uning a food fador of 0.17 derived from Equation $10 \mathrm{and}$ obody weight of $0.02 \mathrm{~kg}$.

- Reponted by ATSDR (1989); baned on food istake of 150 g/day and mean body meigh of $0.8 \mathrm{~kg}$.

'Eatimeted from Equatione 5, 6, and 9, and a boty weighe of $0.8 \mathrm{~kg}$ (es reparted by Bleavine a al., 1980).

\begin{tabular}{|c|c|c|c|c|c|}
\hline Species & $\begin{array}{c}\text { Concentration in } \\
\text { Diet }\end{array}$ & $\begin{array}{l}\text { Daily Dose } \\
\text { (mg/kg) }\end{array}$ & $\begin{array}{l}\text { Exposure } \\
\text { Period }\end{array}$ & Enect & Reference \\
\hline \multicolumn{6}{|c|}{ MAMMAIS: } \\
\hline \multirow[t]{5}{*}{ Rat } & & 1010 & 1 day & $L D_{x_{0}}$ & Garthoff et al., 1981 \\
\hline & $50 \mathrm{mg} / \mathrm{kg}$ food & 2.5 & During gestation & LOAEL, for fetotoxicity & Collins and Capen, 1980 \\
\hline & $25 \mathrm{mg} / \mathrm{kg}$ food & 1.25 & 104 week & LOAEL, reduced survival & $\begin{array}{l}\text { NCI, 1978; } \\
\text { ATSDR, 1989a }\end{array}$ \\
\hline & $>20 \mathrm{mg} / \mathrm{kg}_{\mathrm{g}}$ food & $>1.0$ & 2 generations & $\begin{array}{l}\text { FEL/LOAEL, reduced litter } \\
\text { size }\end{array}$ & Linder et al., 1974 \\
\hline & $<5 \mathrm{mg} / \mathrm{kg}$ food & $<0.25$ & 2 generations & NOAEL & Linder et al., 1974 \\
\hline \multirow[t]{2}{*}{ Rabbit } & & 10.0 & $\begin{array}{l}\text { During gestation } \\
\text { (28 days) } \\
\end{array}$ & NOAEL for fetoxicity & Villeneuve et al., 1971 \\
\hline & & 12.5 & $\begin{array}{l}\text { During gestation } \\
\text { (28 dnys) }\end{array}$ & FEL, fetal deaths & Villeneuve et al., 1971 \\
\hline
\end{tabular}

\subsubsection{Extrapolations to Wildlife Species}

Experimentally derived and extrapolated toxicity values for Aroclor 1254 for representative wildlife species are shown in Table 7. Of the experimentally derived data, the lowest NOAEL is that obtained from the mink $(0.07 \mathrm{mg} / \mathrm{kg})$. Because reproductive changes can adversely affect natural population dynamics, the 9-month exposure can be considered to be equivalent to a chronic condition, and no subchronic to chronic adjustment is needed in the data (as from Equation 22). A body weight of $0.8 \mathrm{~kg}$ is used in the calculation because this is the timeweighted average body weight for females from birth to 10 months of age, the time at which they reach reproductive maturity (EPA, 1987). 
The NOAELs shown in Table 7 illustrate how extrapolated values can vary depending on which set of experimental data is used. The NOAELs for mink that were derived from the data for the white-footed mouse and laboratory rat are $0.05 \mathrm{mg} / \mathrm{kg}$ and $0.19 \mathrm{mg} / \mathrm{kg}$, respectively, whereas the NOAEL from the experimental mink data is $0.07 \mathrm{mg} / \mathrm{kg}$ indicating that the mouse data provide a better estimate of the toxicity of Aroclor 1254 to mink.

The extrapolated NOAELs for the cotton rat and whitetail deer show that there is a threeto four-fold difference between the values derived from the mouse data and those derived from the laboratory rat, whereas the values derived from the mink and mouse data are quite similar. The most conservative benchmark value for Aroclor 1254 would be the NOAEL for whitetail deer $(0.012 \mathrm{mg} / \mathrm{kg})$ extrapolated from the data for the white-footed mouse; however, the NOAEL derived from the mink data $(0.017 \mathrm{mg} / \mathrm{kg})$ is more reliable since the mink value was based on an experimentally derived NOAEL whereas the white-footed mouse value was based on an experimentally derived LOAEL.

For piscivorous species such as mink, a final water quality criterion for Aroclor 1254 can be derived from Equation 16. Bioconcentration factors (BCF) for Aroclor 1254 range from 34,000 to 47,000 for trout and from 34,000 to 307,000 for fathead minnow (Verschueren, 1983). The octanol-water partition coefficient ( $\log P_{\text {oct }}$ ) ranges from 5.6-8.0 (USAF,1989). To be conservative, the diet of mink is assumed to consist entirely of small fish (trophic level 3 , Table 8); therefore, the FCM for Arochlor 1254 ranges from 1 to 7.5. [A minimum FCM of 1 is assumed where $\log P_{o c t}=8.0$. FCMs for values of $\log P_{o c t}>6.5$ are undefined; the U.S. EPA (1993) suggests the FCM $=1.0$ be used in the absence of appropriate data.]

For a NOAEL of $0.07 \mathrm{mg} / \mathrm{kg}$ and a minimum BAF of $34,000(\mathrm{BCF}=34,000 ; \mathrm{FCM}=1)$, the final water quality criterion for mink would be $0.028 \mu \mathrm{g} / \mathrm{L}$ for animals having an average body weight of $0.8 \mathrm{~kg}(\mathrm{~F}=0.057 \mathrm{~kg} / \mathrm{day} ; \mathrm{W}=0.08 \mathrm{~L} /$ day $)$ and $0.032 \mu \mathrm{g} / \mathrm{L}$ for the animals of average body weight of $1.5 \mathrm{~kg}(\mathrm{~F}=0.096 \mathrm{~kg} / \mathrm{day} ; \mathrm{W}=0.14 \mathrm{~L} / \mathrm{day})$. For a maximum $\mathrm{BAF}$ of 2,302,500 $(B C F=307,000 ; F C M=7.5)$, the final criterion would be $427 \mathrm{pg} / \mathrm{L}$ for $0.8 \mathrm{~kg}$ animals and 475 $\mathrm{pg} / \mathrm{L}$ for the larger mink.

\section{SITE-SPECIFIC APPLICATION OF THE METHODOLOGY}

The examples given earlier in this report for trivalent inorganic arsenic and Aroclor 1254 illustrate the extent of the analysis that is required for an understanding of the toxicity of environmental contaminants to wildlife and for the development of benchmark values for mammals. For a complete risk assessment at a particular site similar analyses would be needed for all the chemicals present, as well as information on their physical and chemical state, their concentration in various environmental media, and their bioavailability. The last factor is especially important in estimating environmental impacts. For example, insoluble substances tightly bound to soil particles are unlikely to be taken up by organisms even if ingested. In addition, the chemical or valence state of a contaminant may alter its toxicity such that the different chemical or valence states may have to be treated separately as in the case of trivalent arsenic. Similar problems can be encountered with formulations consisting of mixtures of compounds such as the Aroclors, and each may have to be evaluated separately, unless the relative potency of each of the components can be determined.

For a site-specific assessment, information on the types of wildlife species present, their average body size, and food and water consumption rates would also be needed for calculating 


\begin{tabular}{|c|c|c|c|c|c|c|c|c|c|}
\hline \multirow[t]{2}{*}{ Species } & \multirow{2}{*}{$\begin{array}{l}\text { bw } \\
\text { (kg) }\end{array}$} & \multirow{2}{*}{$\begin{array}{l}\text { Food } \\
\text { factor }\end{array}$} & \multirow{2}{*}{$\begin{array}{l}\text { Water } \\
\text { (L/day) }\end{array}$} & \multirow{2}{*}{$\begin{array}{l}\text { LOAEL } \\
(\mathrm{mg} / \mathrm{kg} / \mathrm{d})\end{array}$} & \multirow[b]{2}{*}{$\begin{array}{c}\text { NOAEL } \\
(\mathrm{mg} / \mathrm{kg} / \mathrm{d})\end{array}$} & \multicolumn{2}{|c|}{ Benchmarks } & \multirow{2}{*}{$\underset{(\mathbf{m g} / \mathbf{k g})}{\mathbf{L}}$} & \multirow{2}{*}{$\begin{array}{l}\text { NOAEL/ } \\
\text { LD }_{\text {so }}\end{array}$} \\
\hline & & & & & & $\begin{array}{c}\text { Diet }^{(s)} \\
\text { (mg/kg food) }\end{array}$ & $\begin{array}{l}\text { Water }^{(15)} \\
(\mathbf{m g} / \mathrm{L})\end{array}$ & & \\
\hline \multicolumn{10}{|c|}{ EXPERIMENTALLY DERIVED VALUES: } \\
\hline White-footed mouse & 0.02 & $0.17^{(10.6)}$ & $0.003^{(19)}$ & 11 & $0.17^{a .11}$ & $1.0^{\circ}$ & 1.1 & & \\
\hline Rat (lab) & 0.35 & 0.05 & 0.049 & & 0.25 & $\$ 0$ & 1.8 & 8010 & 0.0002 \\
\hline Mink & 0.80 & $0.07^{0.9}$ & $0.081^{(19)}$ & & $0.07^{(3)}$ & 1 & $0.69^{f}$ & 125 & 0.06 \\
\hline \multicolumn{10}{|c|}{ EXTRAPOLATED VALUES: } \\
\hline Mink $^{c}$ & 0.80 & $0.07^{0.9}$ & $0.081^{(19)}$ & & $0.05^{(1)}$ & $0.71^{(5)}$ & $0.49^{(13)}$ & & \\
\hline Mink $^{\mathbf{d}}$ & 0.80 & $0.07^{0.9}$ & $0.081^{(10)}$ & & $0.19^{(1)}$ & $2.71^{(5)}$ & $1.83^{(1)}$ & & \\
\hline Cotton rat ${ }^{\mathrm{e}}$ & 0.15 & $0.07^{(10.9}$ & $0.018^{(2)}$ & & $0.09^{(4)}$ & $1.24^{(9)}$ & $0.75^{(1)}$ & & \\
\hline Cotton rat ${ }^{d}$ & 0.15 & $0.07^{(10.0)}$ & $0.018^{(19)}$ & & $0.33^{(4)}$ & $4.70^{(s)}$ & $2.75^{(1)}$ & & \\
\hline Cotton rate & 0.15 & $0.07^{(10.9)}$ & $0.018^{(19)}$ & & $0.12^{(1)}$ & $1.75^{(3)}$ & $1.00^{(12)}$ & & \\
\hline Whitetail deer & 60 & $0.029^{(11.6)}$ & $3.9^{(10)}$ & & $20.012^{(4)}$ & $0.41^{(9)}$ & $0.18^{(1)}$ & & \\
\hline Whitetail deer & 60 & $0.029^{(11.9)}$ & $3.9^{(19)}$ & & $0.045^{(4)}$ & $1.55^{\circ}$ & $0.69^{(19)}$ & . & \\
\hline Whitetail deer & 60 & $0.029^{(11 .)}$ & $3.9^{(10)}$ & & $0.017^{(4)}$ & $0.59^{\circ}$ & $0.26^{(3)}$ & . & \\
\hline
\end{tabular}


Table 8. Aquatic food chain multiplying factors"

\begin{tabular}{|c|c|c|c|}
\hline \multirow{2}{*}{$\log P_{\alpha a}$} & \multicolumn{3}{|c|}{ Prey Trophic Level } \\
\hline & 2 & 3 & 4 \\
\hline$\leq 3.9$ & 1.0 & 1.0 & 1. \\
\hline 4.0 & 1.1 & 1.0 & 1. \\
\hline 4.1 & 1.1 & 1.1 & 1. \\
\hline 4.2 & 1.1 & 1.1 & 1. \\
\hline 4.3 & 1.1 & 1.1 & 1. \\
\hline 4.4 & 1.2 & 1.1 & 1. \\
\hline 4.5 & 1.2 & 1.2 & 1. \\
\hline 4.6 & 1.2 & 1.3 & 1. \\
\hline 4.7 & 1.3 & 1.4 & 1. \\
\hline 4.8 & 1.4 & 1.5 & 1. \\
\hline 4.9 & 1.5 & 1.8 & 2. \\
\hline 5.0 & 1.6 & 2.1 & 2. \\
\hline 5.1 & 1.7 & 2.5 & 3. \\
\hline 5.2 & 1.9 & 3.0 & 4. \\
\hline 5.3 & 2.2 & 3.7 & 5. \\
\hline 5.4 & 2.4 & 4.6 & 8. \\
\hline 5.5 & 2.8 & 5.9 & 11. \\
\hline 5.6 & 3.3 & 7.5 & 16. \\
\hline 5.7 & 3.9 & 9.8 & 23. \\
\hline 5.8 & 4.6 & 13.0 & 33. \\
\hline 5.9 & 5.6 & 17.0 & 47. \\
\hline 6.0 & 6.8 & 21.0 & 67. \\
\hline 6.1 & 8.2 & 25.0 & 75. \\
\hline 6.2 & 10.0 & 29.0 & 84. \\
\hline 6.3 & 13.0 & 34.0 & 92. \\
\hline 6.4 & 15.0 & 39.0 & 98. \\
\hline 6.5 & 19.0 & 45.0 & 100 \\
\hline$>6.5$ & ( $)$ & (c) & (c) \\
\hline
\end{tabular}


NOAELs and environmental criteria. Use of observed values for food and water consumption (if available) are recommended over rates estimated by allometric equations. A list of avian and mammalian species for the DOE Oak Ridge site is given in Appendix C. Since body size of some species can vary geographically, the more specific the data are to the local population the more reliable will be the estimates. Data on body size is especially important in the extrapolation procedure, particularly if calculations of the NOAEL and environmental concentrations are based solely on the adjustment factor as shown in Equation 4. In such cases the lowest NOAEL will be derived from the species with the largest body size.

Information on physiological, behavioral, or ecological characteristics of these species can also be of special importance in determining if certain species are particularly sensitive to a particular chemical or groups of chemicals. If one species occurring at a site is known to be unusually sensitive to a particular contaminant, then the criteria should be based on data for that species (with exceptions noted in the following paragraphs). Similarly, extrapolations from studies on laboratory animals should be based on the most sensitive species unless there is evidence that this species is unusually sensitive to the chemical (e.g., laboratory mice exposed to trivalent inorganic arsenic [Table 4]).

Physiological and biochemical data may be important in determining the mechanism whereby a species' sensitivity to a chemical may be enhanced or diminished. Such information would aid in determining whether data for that species would be appropriate for developing criteria for other species. For example, if the toxic effects of a chemical are related to the induction of a specific enzyme system, as is the case with PCBs, then it would be valuable to know whether physiological factors (enzyme activity levels per unit mass of tissue or rates of synthesis of the hormones affected by the induced enzymes) in the most sensitive species are significantly different from those of other species of wildlife. Furthermore, if the most sensitive species, or closely related species, do not occur at a particular site, then a less stringent criteria might be acceptable.

Physiological data may also reveal how rates of absorption and bioavailability vary with exposure routes and/or exposure conditions. Gastrointestinal absorption may be substantially different depending on whether the chemical is ingested in the diet or in drinking water. Thus, a NOAEL based on a laboratory drinking water study may be inappropriate to use in extrapolating to natural populations that would only be exposed to the same chemical in their diet. The diet itself may affect gastrointestinal absorption rates. In the case of the mink exposed to PCBs, their diet consists primarily of contaminated fish in which the PCBs are likely to be concentrated in fatty tissues. This may result in a different rate of gastrointestinal absorption than that occurring in laboratory rodents dosed with PCBs in dry chow.

Behavioral and ecological data might also explain differences in sensitivity between species. Certain species of wildlife may be more sensitive because of higher levels of environmental stress to which they are subjected. This may be especially true of populations occurring at the periphery edges of their normal geographic range. Conversely, laboratory animals maintained under stable environmental conditions of low stress may have higher levels of resistance to toxic chemicals.

As a first step in developing wildlife criteria for chemicals of concern at DOE sites, relevant toxicity data for wildlife and laboratory animals have been compiled (Appendixes A and B). These data consist primarily of NOAELs, LOAELs, and $\mathrm{LD}_{s 0} \mathrm{~s}$ for mammalian species. No methodology is currently available for extrapolating from mammalian studies to nonmammalian terrestrial vertebrates (i.e., birds, reptiles, and amphibians), and no attempt has been made to do 
so in this report. The limited experimental data on birds pertain largely to acute toxicity; however, a few subchronic and chronic studies have been reported and these are cited where appropriate. No pertinent data on non-pesticide chemicals were found for amphibians, reptiles, or terrestrial invertebrates. Additional chronic exposure studies are needed before toxicological benchmarks can be developed for these groups.

The ideal data to use for evaluating chronic exposures is the time-weighted average (TWA) body weight for the entire life span of the species. While rarely available for wildlife, the TWA body weight for mink through age 450 days was calculated to be about $1.35 \mathrm{~kg}$ (EPA, 1987). The TWA body weight for the entire life span was estimated to be about $1.5 \mathrm{~kg}$, only slightly less than average adult size of about $1.6 \mathrm{~kg}$. Very approximate estimates of average body weights for the other species were based on the available data (Table 9). These values were then used to calculate body surface area scaling factors from Equation 4 (Table 9) and also to derive food factors from Equations 6 and 9-11 and water consumption values from Equation 19 (Table 10).

For piscivorous species (mink, belted kingfisher, great blue heron) that may be exposed to contaminants through both diet and water, a final water criterion was calculated by using the aquatic life BAF as given in Equation 16. BAFs were estimated by multiplying the aquatic life bioconcentration factor (BCF) for the contaminant by the food chain multiplier (Table 8) appropriate for the wildlife species of concern (EPA, 1993). In cases where the BCF for a particular compound was not available, it was estimated from the octanol-water partition coefficient of the compound by the following relationship (Lyman et al., 1980):

$$
\log \mathrm{BCF}=0.76 \log \mathrm{P}_{\mathrm{oct}}-0.23
$$

The BCF can also be estimated from the water solubility of a compound by the following regression equation (Lyman et al., 1982):

$$
\log \mathrm{BCF}=2.791-0.564 \log \mathrm{WS}
$$

where WS is the water solubility in $\mathrm{mg} / \mathrm{kg}$ water.

Pertinent $\log \mathrm{P}$ values, water solubility data, and reported or calculated BCF values for the chemicals on the preliminary DOE list are included on Table 11. The BCF values listed represent the ranges determined by the various methods as well as any experimental values reported in the literature. Ideally, the BCF values used should be those for the primary prey species; however, because this information is rarely available, the ranges provide upper and lower bounds to the estimate.

The results of the analyses are presented in Tables 12 (mammals) and 13 (birds). Because of the consistency of the body weight differences for the selected mammalian wildlife species, the calculated NOAELs exhibit about a 15-fold range between the species of smallest body size (short-tailed shrew) and that of the largest body size (whitetail deer). In terms of dietary intake, the range in values is much less (2-3 fold) thereby indicating that equivalent dietary levels of a chemical result in nearly equivalent doses between species because food intake is a function of metabolic rate which, in turn, is a function of body size (EPA, 1980). However, according to EPA, the correlation is not exact because food intake also varies with moisture and caloric content of the food, and it should be noted that in laboratory feeding experiments, the test animals are usually dosed with the chemical in a dry chow. Therefore, it would be expected that the food 
factor for a species of wildlife would be relatively higher than that of a related laboratory species of comparable body size.

Few long-term, multigeneration studies on wildlife or laboratory animals have been conducted on chemicals of concern to the DOE. Consequently, the extrapolated NOAELs listed in Tables 12 and 13 cannot be considered as absolute safe levels, particularly in terms of potential population effects since subtle reproductive changes may occur at or below levels producing overt toxicological signs. Although more in-depth analyses of the toxicity of each chemical, as given in preceding paragraphs for trivalent arsenic and Aroclor 1254, might provide some indication as to whether such effects might occur, only multigeneration studies would provide conclusive results. 


\begin{tabular}{|c|c|c|c|c|}
\hline \multicolumn{2}{|c|}{ Experimental Animals } & \multicolumn{2}{|c|}{ Wildlife } & \multirow[b]{2}{*}{$\begin{array}{c}\text { Scaling factor } \\
\left(\mathbf{b w}_{\mathbf{f}} / \mathbf{b w}_{\mathbf{w}}\right)^{1 \mathrm{~s}}\end{array}$} \\
\hline Species & $\begin{array}{l}\text { Body Weight (bw, } \\
\text { in kg) }\end{array}$ & Species & $\begin{array}{l}\text { Body weight' (bw. } \\
\text { in } \mathbf{k g})\end{array}$ & \\
\hline rat & 0.35 & short-tailed shrew & 0.015 & 2.828 \\
\hline rat & 0.35 & white-footed mouse & 0.02 & 2.596 \\
\hline rat & 0.35 & cottontail rabbit & 1.0 & 0.705 \\
\hline rat & 0.35 & mink & 1.5 & 0.616 \\
\hline rat & 0.35 & red fox & 6.0 & 0.388 \\
\hline rat & 0.35 & whitetail deer & 60.0 & 0.180 \\
\hline mouse & 0.03 & short-tailod shrew & 0.015 & 1.26 \\
\hline mouse & 0.03 & white-footod mouse & 0.02 & 1.14 \\
\hline mouse & 0.03 & cottontail rabbit & 1.0 & 0.311 \\
\hline mouse & 0.03 & mink & 1.5 & 0.271 \\
\hline mouse & 0.03 & red fox & 6.0 & 0.171 \\
\hline mouse & 0.03 & whitelail deer & 60 & 0.079 \\
\hline dog & 12.7 & short-tailed shrew & 0.015 & 9.439 \\
\hline dog & 12.7 & white-footed mouse & 0.02 & 8.595 \\
\hline dog & 12.7 & cottontail rabbit & 1.0 & 2.333 \\
\hline $\operatorname{dog}$ & 12.7 & mink & 1.5 & 2.038 \\
\hline $\operatorname{dog}$ & 12.7 & $\operatorname{rod} f o x$ & 6.0 & 1.284 \\
\hline dog & 12.7 & whitetail deer & 60.0 & 0.596 \\
\hline rabbit & 3.8 & short-tailod shrew & 0.015 & 6.32 \\
\hline rabbit & 3.8 & white-footed mouse & 0.02 & 5.75 \\
\hline rabbit & 3.8 & cottontail rabbit & 1.0 & 1.56 \\
\hline rabbit & 3.8 & mink & 1.5 & 1.36 \\
\hline rabbit & 3.8 & $\operatorname{red}$ fox & 6.0 & 0.859 \\
\hline rabbit & 3.8 & whitetail deer & 60.0 & 0.399 \\
\hline human & 70 & short-tailed shrew & 0.015 & 16.664 \\
\hline human & 70 & white-footed mouse & 0.02 & 15.183 \\
\hline human & 70 & cottontail rabbit & 1.0 & 4.121 \\
\hline human & 70 & mink & 1.5 & 3.600 \\
\hline human & 70 & $\operatorname{red}$ fox & 6.0 & 2.268 \\
\hline human & 70 & whitetail deer & 60 & 1.053 \\
\hline
\end{tabular}

- Standard referenoe values uod by EPA.

- Estimaled from dalu in Appendix C-I. 


\begin{tabular}{|c|c|c|c|c|c|}
\hline Species & $\begin{array}{l}\text { bw } \\
(\mathrm{kg})\end{array}$ & $\begin{array}{c}\text { Food Intake } \\
\text { (kg/day) }\end{array}$ & $\begin{array}{c}\text { Food factor } \\
(f)\end{array}$ & $\begin{array}{c}\text { Water Intake } \\
(\mathrm{L} / \text { day })^{(19)}\end{array}$ & $\begin{array}{c}\text { Water factor } \\
(\omega)\end{array}$ \\
\hline rat & $0.35^{b}$ & 0.027 & $0.050^{b}$ & $0.049^{b}$ & 0.14 \\
\hline mouse & $0.03^{b}$ & 0.004 & $0.13^{b}$ & $0.0057^{\circ}$ & 0.19 \\
\hline rabbit & $3.8^{b}$ & 0.186 & $0.049^{b}$ & $0.41^{b}$ & 0.108 \\
\hline $\operatorname{dog}$ & $12.7^{\circ}$ & 0.317 & $0.025^{b}$ & $0.61^{b}$ & 0.048 \\
\hline short-tailed shrew & $0.015^{c}$ & 0.002 & 0.19 & 0.002 & 0.15 \\
\hline white-footed mouse & $0.02^{c}$ & 0.003 & $0.17^{(10.9)}$ & $0.003^{(10)}$ & 0.15 \\
\hline cottontail rabbit & $1.0^{\circ}$ & 0.069 & $0.069^{(11,9)}$ & $0.099^{(10)}$ & 0.099 \\
\hline mink & $1.5^{\mathrm{c}}$ & 0.096 & $0.064^{0.0}$ & $0.143^{(19)}$ & 0.095 \\
\hline red fox & $6.0^{c}$ & 0.300 & $0.050^{\circ .0}$ & $0.497^{(19)}$ & 0.083 \\
\hline whitetail deer & $60^{\circ}$ & 1.717 & $0.0286^{(11.0)}$ & $3.94^{(19)}$ & 0.066 \\
\hline
\end{tabular}

- Numbers in parentheses refer to equations in text.

- EPA standard reference values.

- Average adult body weights estimated from data given in Appendix C-1.

- The water factor is the water intake divided by the body weight.

\begin{tabular}{||l|c|c|c|c||}
\hline \multicolumn{5}{|c|}{$\begin{array}{c}\text { Table 11. Octanol-water partition coefficients, } \\
\text { water solubility data and bioconcentration factors }\end{array}$} \\
\hline Chemical & log P & $\begin{array}{c}\text { Water } \\
\text { Solubility } \\
\text { (mg/L) }\end{array}$ & BCF & References \\
\hline Acetone & -0.24 & infinite & $0.39-0.99$ & USAF, 1989 \\
\hline Benzene & $1.56-2.28$ & 1,780 & $6.5-23$ & USAF, 1989; \\
\hline Benzo[a]pyrene & 6.06 & $3.8 \times 10^{\circ}$ & $23,746^{\circ}$ & Mabey et al. 1982 \\
\hline Carbon tetrachloride & $0.35-2.83$ & 800 & $2-83$ & USAF, 1989 \\
\hline Chlordane & 5.48 & 0.056 & 14100 & USAF, 1989 \\
\hline Chloroform & 1.97 & 822 & $15-19$ & USAF, 1989 \\
\hline Cyanide & 0.66 & miscible & $2-72$ & USAF, 1989 \\
\hline DDT & 6.36 & $0.0031-0.0034$ & $38,000-110,000$ & USAF, 1989 \\
\hline Di-N-butylphthalate & 4.57 & 4500 & $8.9-1800$ & USAF, 1989 \\
\hline 1,1-Dichloroethylene & 2.13 & 400 & $6-24$ & USAF, 1989 \\
\hline 1,2-Dichloroethylene & 1.86 & 3,500 & $4.5-15$ & USAF, 1989 \\
\hline
\end{tabular}




\begin{tabular}{|c|c|c|c|c|}
\hline \multicolumn{5}{|c|}{$\begin{array}{l}\text { Table 11. Octanol-water partition coefficients, } \\
\text { water solubility data and bioconcentration factors }\end{array}$} \\
\hline Chemical & $\log P$ & $\begin{array}{c}\text { Water } \\
\text { Solubility } \\
\text { (mg/L) }\end{array}$ & BCF & References \\
\hline Di-2-ethylhexylphthalate & $3.98 ; 5.11$ & 4 & $330-6200$ & USAF, 1989 \\
\hline Ethyl acetate & & $79,000-86,000$ & $1.0-1.1$ & Verschueren, 1983 \\
\hline Fuel Oil No. 2 & $3.30-7.06$ & 5 & 249 & USAF, 1989 \\
\hline Fuel Oil No. 6 & $3.30-7.06$ & 5 & 249 & USAF, 1989 \\
\hline Methanol & $-0.82 ;-0.66$ & & $0.14 \cdot 0.58$ & Verschueren, 1983 \\
\hline Methylene chloride & 1.25 & 13,200 & $5-80$ & USAF, 1989 \\
\hline Methyl ethyl ketone & 0.29 & 353,000 & $0.1-2$ & USAF, 1989 \\
\hline $\begin{array}{l}\text { 4-Methyl-2-pentanone } \\
\text { (Methyl isobutyl ketone) }\end{array}$ & & $17,000-19,100$ & $2.4-2.5$ & $\begin{array}{l}\text { Verschueren, 1983; } \\
\text { Merck Index }\end{array}$ \\
\hline PCBs: & & & & \\
\hline Aroclor 1016 & $5.30-5.60$ & $0.2-0.9$ & $992-10,617$ & USAF, 1989 \\
\hline Aroclor 1242 & $5.30-6.10$ & $0.2-0.7$ & $992-25,468$ & USAF, 1989 \\
\hline Aroclor 1254 & $5.60-8.00$ & $0.1-0.07$ & $1,442-707,945$ & USAF, 1989 \\
\hline Aroclor 1260 & $6.10-9.30$ & 0.0027 & $2,693-6,886,523$ & USAF, 1989 \\
\hline $2,3,7,8$ TCDD & $6.15-7.28$ & $7.91 ; 19.3 \mathrm{mg} / \mathrm{L}$ & $27,797-200,81 \theta$ & AT SDR, $1989 \mathrm{~b}$ \\
\hline Tetrachloroethylene & $1.59 ; 3.14$ & 150 & $9.5-143$ & $\begin{array}{l}\text { Verschueren, 1983; } \\
\text { USAF, } 1989\end{array}$ \\
\hline Tetrahydrofuran & & miscible & & Verschueren, 1983 \\
\hline Toluene & $2.73 ; 2.80$ & 515 & $26-79$ & $\begin{array}{l}\text { USAF, 1989; } \\
\text { Verschueren, } 1989\end{array}$ \\
\hline 1,1,1-Trichloroethane & 2.49 & 950 & $5.6-46$ & USAF, 1989 \\
\hline Trichloroethylene & 2.42 & 1,000 & $13-41$ & USAF, 1989 \\
\hline Vinyl chloride & 1.23 & 1,100 & $0.8-6$ & USAF, 1989 \\
\hline Xylene & 3.16 & & 7 & USAF, 1989 \\
\hline
\end{tabular}

- Values estimated using equation 24. 


\begin{tabular}{|c|c|c|c|c|c|c|c|c|c|}
\hline \multirow[b]{3}{*}{ Chemical - exp. animal } & \multirow[b]{3}{*}{ Wildlife } & \multirow{2}{*}{\multicolumn{3}{|c|}{ Experimental Values ${ }^{b}$}} & \multicolumn{4}{|c|}{ Extrapolated Values for Chronic Exposures } & \multirow[b]{3}{*}{$\begin{array}{c}\text { References } \\
\text { (LOAEL/NOAEL) }\end{array}$} \\
\hline & & & & & \multirow{2}{*}{$\underset{\text { (mg/kg/day) }}{\text { NOAEL }}$} & \multicolumn{3}{|c|}{ Toxicological Benchmarks } & \\
\hline & & $\underset{\text { (mg/kg/day) }}{\text { LOAEL }}$ & $\underset{(\mathrm{mg} / \mathrm{kg} / \mathrm{day})}{\text { NOAEL }}$ & Endpoint & & $\begin{array}{c}\mathrm{Dier}_{(m)} \\
\text { (mg/kg food) }\end{array}$ & $\begin{array}{l}\text { Water } \\
(\mathrm{mg} / \mathrm{L})\end{array}$ & $\begin{array}{c}\text { Final Water } \\
\text { Crit. } \\
\text { (mg/L) } \\
\end{array}$ & \\
\hline \multicolumn{2}{|l|}{ Acetone - rat } & 500 (90 days) & 100 (90 days) & $\begin{array}{c}\text { liver and } \\
\text { kidney }\end{array}$ & $10^{(2)}$ & & & & EPA, 1986c \\
\hline & short-tailed shrew & & & & 28 & 148 & 188 & & \\
\hline & white-footed mouse & & & & 26 & 153 & 176 & & \\
\hline & cottontail rabbit & & & & 7.1 & 81 & 71 & & \\
\hline & mink & & & & 6.2 & 97 & 65 & $39-51$ & \\
\hline & red fox & & & & 3.9 & 78 & 47 & & \\
\hline & whitetail deer & & & & 1.8 & 64 & 28 & & \\
\hline \multicolumn{2}{|l|}{ Soluble arsenite - mouse } & 0.95 (3 gen) & & reproduction & $0.095^{211}$ & & & & \\
\hline & shon-tailed shrew & & & & 0.12 & 0.63 & 0.79 & & Schroeder and Mitchner, 1971 \\
\hline & white-footed mouse & & & & 0.11 & 0.65 & 0.74 & & \\
\hline & cottontail rabbit & & & & 0.03 & 0.34 & 0.30 & & \\
\hline & mink & & & & 0.026 & 0.41 & 0.27 & & \\
\hline & red fox & & & & 0.017 & 0.33 & 0.20 & & \\
\hline & whitetail deer & & & & 0.008 & 0.27 & 0.12 & & \\
\hline
\end{tabular}




\begin{tabular}{|c|c|c|c|c|c|c|c|c|c|}
\hline \multirow[b]{3}{*}{ Chemical - exp. animal } & \multirow[b]{3}{*}{ Wildlife } & \multirow{2}{*}{\multicolumn{3}{|c|}{ Experimental Values ${ }^{b}$}} & \multicolumn{4}{|c|}{ Extrapolated Values for Chronic Exposures } & \multirow[b]{3}{*}{$\begin{array}{c}\text { References } \\
\text { (LOAEL/NOAEL) }\end{array}$} \\
\hline & & & & & \multirow{2}{*}{$\begin{array}{c}\text { NOAEL } \\
(\mathrm{mg} / \mathbf{k g} / \mathrm{day})\end{array}$} & \multicolumn{3}{|c|}{ Toxicological Benchmarks } & \\
\hline & & $\begin{array}{c}\text { LOAEL } \\
(\mathrm{mg} / \mathrm{kg} / \mathrm{day})\end{array}$ & $\begin{array}{c}\text { NOAEL } \\
(\mathrm{mg} / \mathrm{kg} / \mathrm{day})\end{array}$ & Endpoint & & $\begin{array}{c}\text { Diers) } \\
(\mathrm{mg} / \mathrm{kg} \text { food })\end{array}$ & $\begin{array}{l}\text { Water's) } \\
(\mathrm{mg} / \mathrm{L})\end{array}$ & $\begin{array}{c}\text { Final Water } \\
\text { Crit. } \\
(\mathrm{mg} / \mathrm{L})^{100 x}\end{array}$ & \\
\hline \multicolumn{2}{|l|}{ Asbestos - rat } & & 500 & reproduction & $50^{203}$ & & & & ATSDR , 1990a \\
\hline & shor-tailed shrew & & & & 141 & 741 & 938 & & \\
\hline & white-footed mouse & & & & 129 & 764 & 878 & & \\
\hline & cottontail rabbit & & & & 35 & 404 & 357 & & \\
\hline & mink & & & & 31 & 484 & 325 & & \\
\hline & red fox & & & & 20 & 392 & 237 & & \\
\hline & whitetail deer & & & & 9 & 320 & 139 & & \\
\hline \multicolumn{2}{|l|}{ Barium - rat } & $5.1(16 \mathrm{mo})$ & $0.51(16 \mathrm{mo})$ & cardiovascular & 0.51 & & & & Perry et al., 1983 \\
\hline & short-tailed shrew & & & & 1.44 & 7.6 & 9.6 & & \\
\hline & white-footed mouse & & & & 1.31 & 7.8 & 9.0 & & \\
\hline & cottontail rabbit & & & & 0.36 & 4.1 & 3.6 & & \\
\hline & mink & & & & 0.32 & 4.9 & 3.3 & & \\
\hline & red fox & & & & 0.20 & 4.0 & 2.4 & & \\
\hline & whitetail deer & & & & 0.09 & 3.3 & 1.4 & & \\
\hline
\end{tabular}




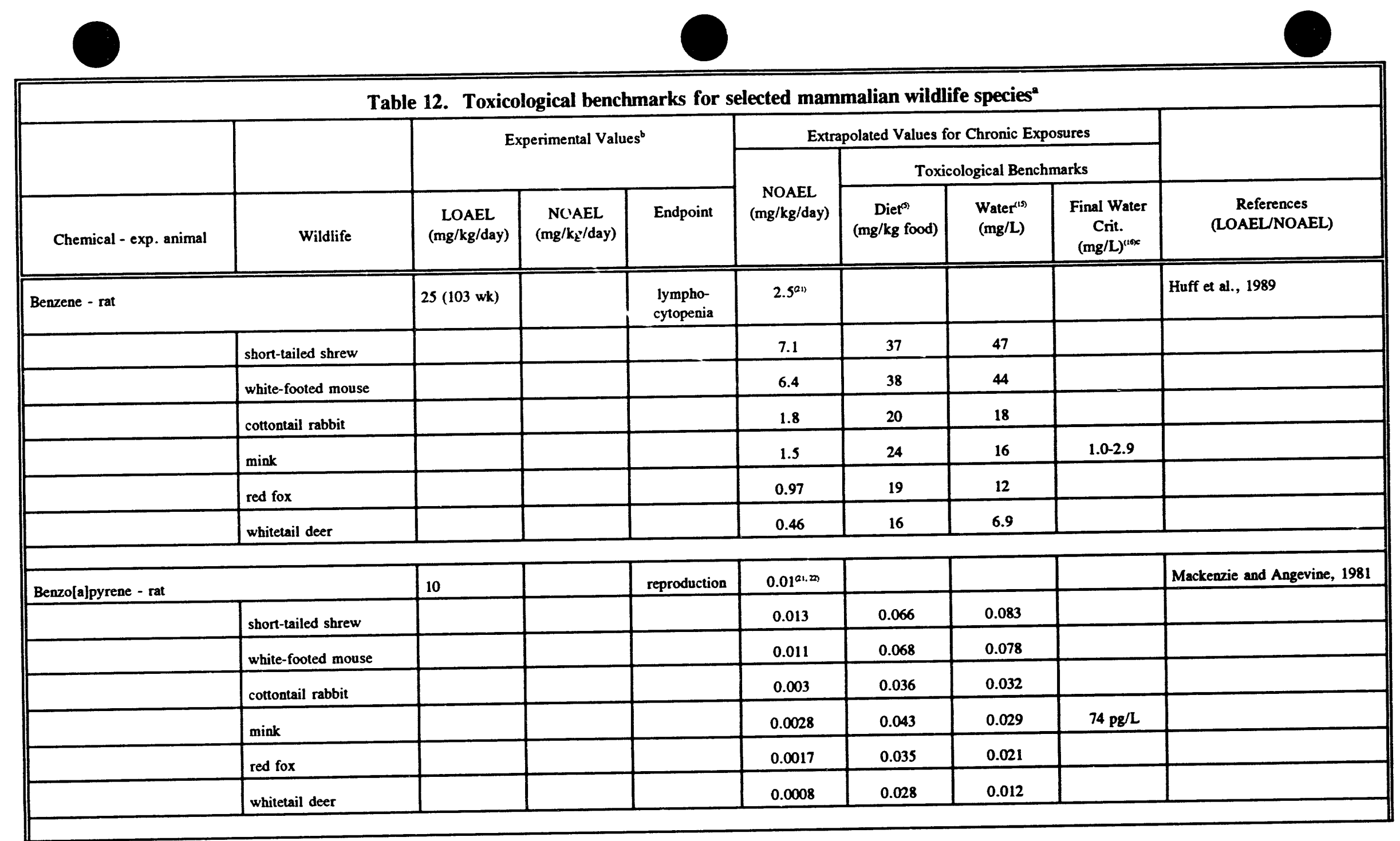




\begin{tabular}{|c|c|c|c|c|c|c|c|c|c|}
\hline \multirow[b]{3}{*}{ Chemical - exp. animal } & \multirow[b]{3}{*}{ Wildlife } & \multirow{2}{*}{\multicolumn{3}{|c|}{ Experimental Values' }} & \multicolumn{4}{|c|}{ Extrapolated Values for Chronic Exposures } & \multirow[b]{3}{*}{$\begin{array}{c}\text { References } \\
\text { (LOAEL/NOAEL) }\end{array}$} \\
\hline & & & & & \multirow{2}{*}{$\underset{(\mathrm{mg} / \mathrm{kg} / \mathrm{day})}{\mathrm{NOAEL}}$} & \multicolumn{3}{|c|}{ Toxicological Benchmarks } & \\
\hline & & $\begin{array}{c}\text { LOAEL } \\
\text { (mg/kg/day) }\end{array}$ & $\underset{(\mathrm{mg} / \mathrm{kg} / \mathrm{day})}{\mathrm{NOAEL}}$ & Endpoint & & $\begin{array}{c}\text { Diet } \\
\text { (mg/kg food) }\end{array}$ & $\begin{array}{l}\text { Water'is } \\
(\mathrm{mg} / \mathrm{L})\end{array}$ & $\begin{array}{c}\text { Final Water } \\
\text { Crit. } \\
(\mathrm{mg} / \mathrm{L})^{\cos x}\end{array}$ & \\
\hline \multicolumn{2}{|l|}{ Beryllium - rat } & $443(83 d)$ & $0.54(1126 \mathrm{~d})$ & bone; wt. loss & 0.54 & & & & $\begin{array}{l}\text { Businco, 1940/ Schroeder and } \\
\text { Mitchener, } 1975\end{array}$ \\
\hline & short-tailed shrew & & & & 1.53 & 8.00 & 10.13 & & \\
\hline & white-footed mouse & & & & 1.39 & 8.26 & 9.48 & & \\
\hline & cottontail rabbit & & & . & 0.38 & 4.36 & 3.86 & & \\
\hline & mink & & & & 0.33 & 5.23 & 3.51 & & \\
\hline & red fox & & & & 0.21 & 4.23 & 2.55 & & \\
\hline & whitetail deer & & & & 0.09 & 3.46 & 1.50 & & \\
\hline \multicolumn{2}{|l|}{ Di-N-butylphthalate - mouse } & & $423(105 d)$ & reproduction & $42.3^{(2)}$ & & & & Lamb et al., 1987 \\
\hline & short-tailed shrew & & & & 53.2 & 278.8 & 352.9 & & \\
\hline & white-footed mouse & & & & 48.4 & 287.5 & 330.1 & & \\
\hline & cottontail rabbit & & & & 13.3 & 152.0 & 134.3 & & \\
\hline & mink & & & & 11.6 & 181.9 & 122.3 & $0.08-13.9$ & \\
\hline & red fox & & & & 7.46 & 147.4 & 88.9 & & \\
\hline & whitetail deer & & & & 3.4 & 120.2 & 52.3 & & \\
\hline
\end{tabular}


Table 12. Toxicological benchmarks for selected mammalian wildlife species ${ }^{2}$

\begin{tabular}{|c|c|c|c|c|c|c|c|c|c|}
\hline \multirow[b]{3}{*}{ Chemical - exp. aninal } & \multirow[b]{3}{*}{ Wildlife } & \multirow{2}{*}{\multicolumn{3}{|c|}{ Experimental Values ${ }^{\mathrm{b}}$}} & \multicolumn{4}{|c|}{ Extrapolated Values for Chronic Exposures } & \multirow[b]{3}{*}{$\begin{array}{c}\text { References } \\
\text { (LOAEL/NOAEL) }\end{array}$} \\
\hline & & & & & \multirow{2}{*}{$\begin{array}{c}\text { NOAEL } \\
\text { (mg/kg/day) }\end{array}$} & \multicolumn{3}{|c|}{ Toxicological Benchmarks } & \\
\hline & & $\underset{(\mathrm{mg} / \mathrm{kg} / \mathrm{day})}{\text { LOAEL }}$ & $\underset{(\mathrm{mg} / \mathrm{kg} / \mathrm{day})}{\text { NOAEL }}$ & Endpoint & & $\begin{array}{c}\text { Diete } \\
\text { (mg/kg food) }\end{array}$ & $\begin{array}{l}\text { Water'19) } \\
(\mathrm{mg} / \mathrm{L})\end{array}$ & $\begin{array}{c}\text { Final Water } \\
\text { Crit. } \\
(\mathrm{mg} / \mathrm{L})^{\operatorname{1006}}\end{array}$ & \\
\hline \multicolumn{2}{|l|}{ Carbon tetrachloride - rat } & $10(12 \mathrm{wk})$ & $0.71(12 \mathrm{wk})$ & liver, necrosis & $0.071^{203}$ & 0.91 & 0.51 & & Bruckner et al., 1986 \\
\hline & short-tailed shrew & & & & 0.201 & 1.05 & 1.33 & & \\
\hline & white-footed mouse & & & & 0.183 & 1.09 & 1.25 & & \\
\hline & cottontail rabbit & & & & 0.050 & 0.57 & 0.51 & & \\
\hline & mink & & & & 0.044 & 0.69 & 0.46 & $0.008-0.20$ & \\
\hline & red fox & & & & 0.028 & 0.56 & 0.34 & & \\
\hline & whitetail deer & & & & 0.013 & 0.45 & 0.20 & & \\
\hline & & & & & & & & & \\
\hline & & & & & & & & & \\
\hline & & & & & & & & & \\
\hline & & & & & & & & & \\
\hline & & & & & & & & & \\
\hline & & & & & & & & & \\
\hline Chloroform - rat & & & & Lidnet I & sect & 118 & 6 & & Reuher 1979 \\
\hline & & $90(78 w k)$ & & & 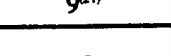 & 115 & 64 & 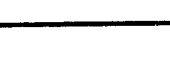 & \begin{tabular}{|l} 
Rever, \\
\end{tabular} \\
\hline & \begin{tabular}{|l} 
short-tailed shrew \\
\end{tabular} & & & & 25 & 133 & 169 & & \\
\hline & white-footed mouse & & & & 23 & 138 & 158 & & \\
\hline Chloroform - dog & & $12.9(7.5 \mathrm{yr})$ & & $\begin{array}{c}\text { liver, fatty } \\
\text { cysts }\end{array}$ & $1.29^{a n}$ & & & & Heywood et al., 1979 \\
\hline & cottontail rabbit & & & & 2.98 & 34 & 30 & & \\
\hline & mink & & & & 2.61 & 41 & 27 & 2.01-2.49 & \\
\hline & red fox & & & & 1.65 & 33 & 20 & & \\
\hline & whitetail deer & & & & 0.77 & 27 & 12 & & \\
\hline
\end{tabular}




\begin{tabular}{|c|c|c|c|c|c|c|c|c|c|}
\hline \multirow[b]{3}{*}{ Chemical - exp. animal } & \multirow[b]{3}{*}{ Wildlife } & \multirow{2}{*}{\multicolumn{3}{|c|}{ Experimental Values $^{b}$}} & \multicolumn{4}{|c|}{ Extrapolated Values for Chronic Exposures } & \multirow[b]{3}{*}{$\begin{array}{c}\text { References } \\
\text { (LOAEL/NOAEL) }\end{array}$} \\
\hline & & & & & \multirow{2}{*}{$\begin{array}{c}\text { NOAEL } \\
(\mathrm{mg} / \mathrm{kg} / \mathrm{day})\end{array}$} & \multicolumn{3}{|c|}{ Toxicological Benchmarks } & \\
\hline & & $\begin{array}{c}\text { LOAEL } \\
\text { (mg/kg/day) }\end{array}$ & $\begin{array}{c}\text { NOAEL } \\
(\mathrm{mg} / \mathrm{kg} / \text { day })\end{array}$ & Endpoint & & $\begin{array}{c}\text { Diet } \\
\text { (mg/kg food) }\end{array}$ & $\begin{array}{l}\text { Water }{ }^{19} \\
\text { (mg/L) }\end{array}$ & $\begin{array}{c}\text { Final Water } \\
\text { Crit. } \\
(\mathrm{mg} / \mathrm{L})^{\text {ans }}\end{array}$ & \\
\hline \multicolumn{2}{|l|}{ Chromium VI -rat } & & $2.4(2 \mathrm{yr})$ & & 2.4 & & & & Mackenzie et al., 1958 \\
\hline & short-tailed shrew & & & & 6.79 & 36 & 45 & & \\
\hline & white-footed mouse & & & & 6.17 & 37 & 42 & & \\
\hline & cottontail rabbit & & & & 1.70 & 19 & 17 & & \\
\hline & mink & & & & 1.48 & 23 & 16 & & \\
\hline & red fox & & & & 0.94 & 19 & 11 & & \\
\hline & whitetail deer & & & & 0.44 & 15 & 7 & & \\
\hline \multirow[t]{7}{*}{ Cyanide - rat } & & & $10.8(104 \mathrm{wk})$ & & 10.8 & & & & Howard and Hanzal, 1955 \\
\hline & shor-tailed shrew & & & & 30.5 & 160 & 203 & & \\
\hline & white-footed mouse & & & & 27.8 & 165 & 190 & & \\
\hline & cottontail rabbit & & & & 7.6 & 87 & 77 & & \\
\hline & $\operatorname{mink}$ & & & & 6.7 & 105 & 70 & $1.4-30$ & \\
\hline & red fox & & & & 4.2 & 85 & 51 & & \\
\hline & whitetail deer & & & & 2.0 & 69 & 30 & & \\
\hline
\end{tabular}




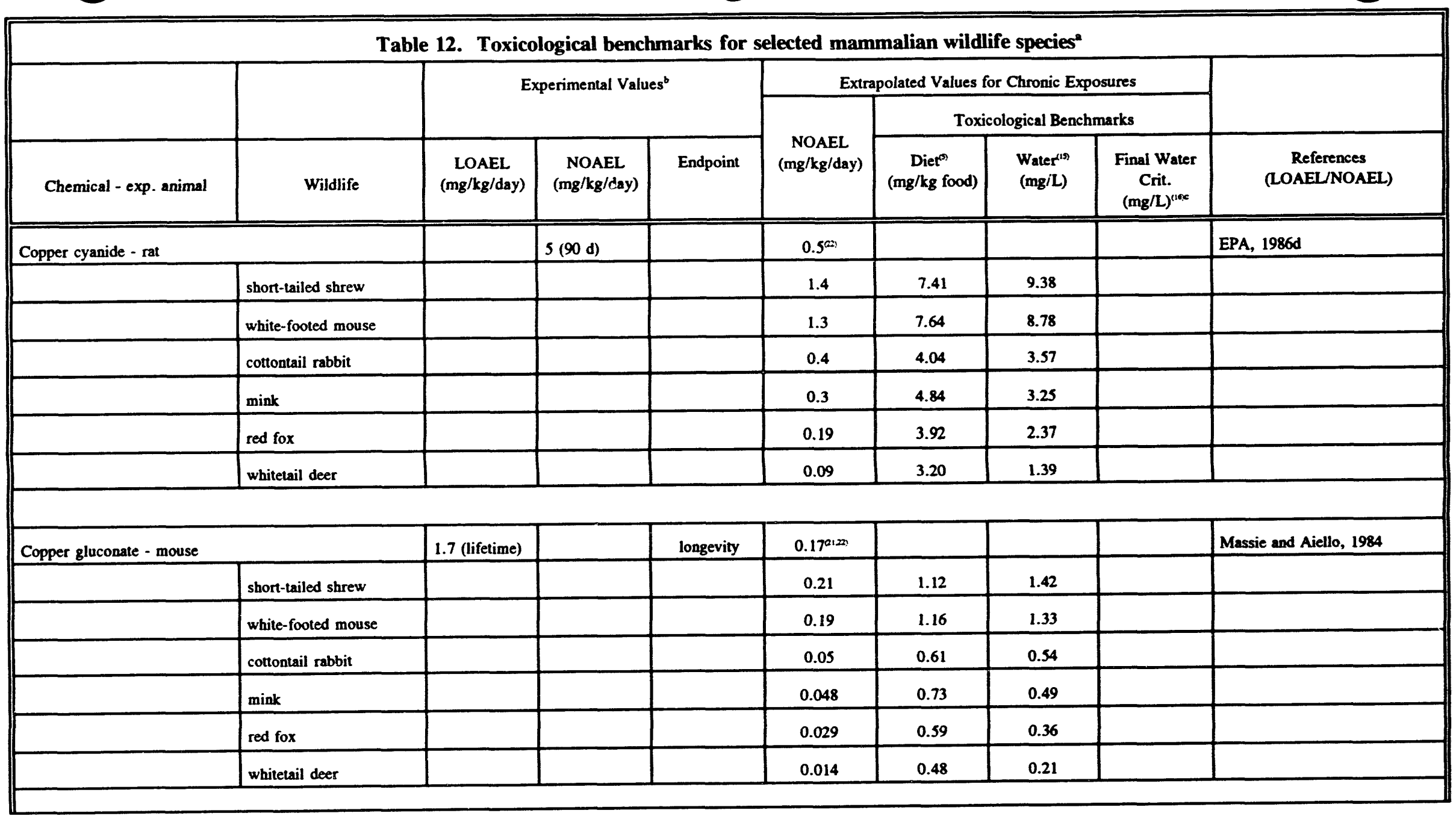




\begin{tabular}{|c|c|c|c|c|c|c|c|c|c|}
\hline \multirow[b]{3}{*}{ Chemical - exp. animal } & \multirow[b]{3}{*}{ Wildlife } & \multirow{2}{*}{\multicolumn{3}{|c|}{ Experimental Values ${ }^{b}$}} & \multicolumn{4}{|c|}{ Extrapolated Values for Chronic Exposures } & \multirow[b]{3}{*}{$\begin{array}{c}\text { References } \\
\text { (LOAEL/NOAEL) }\end{array}$} \\
\hline & & & & & \multirow{2}{*}{$\begin{array}{c}\text { NOAEL } \\
\text { (mg/kg/day) }\end{array}$} & \multicolumn{3}{|c|}{ Toxicological Benchmarks } & \\
\hline & & $\begin{array}{c}\text { LOAEL } \\
\text { (mg/kg/day) }\end{array}$ & $\begin{array}{c}\text { NOAEL } \\
\text { (mg/kg/day) }\end{array}$ & Endpoint & & $\begin{array}{c}\text { Diets) } \\
(\mathrm{mg} / \mathrm{kg} \text { food })\end{array}$ & $\begin{array}{l}\text { Water/s) } \\
(\mathrm{mg} / \mathrm{L})\end{array}$ & $\begin{array}{c}\text { Final Water } \\
\text { Crit. } \\
(\mathrm{mg} / \mathrm{L})^{\text {aloc }}\end{array}$ & \\
\hline \multicolumn{2}{|l|}{ Copper sulphate - rat } & & 14 (4 wk) & $\begin{array}{l}\text { growth; food } \\
\text { consumption }\end{array}$ & $1.4^{\infty}$ & & & & Boyden et al., 1938 \\
\hline & short-tailed shrew & & & & 3.9 & 20.8 & 26.3 & & \\
\hline & white-footed mouse & & & & 3.6 & 21.4 & 24.6 & & \\
\hline & cottontail rabbit & & & & 0.99 & 11.3 & 10.0 & & \\
\hline & $\operatorname{mink}$ & & & & 0.87 & 13.5 & 9.1 & & \\
\hline & red fox & & & & 0.55 & 10.9 & 6.6 & & \\
\hline & whitetail deer & & & & 0.26 & 8.9 & 3.9 & & \\
\hline \multicolumn{2}{|l|}{\begin{tabular}{|l} 
1,2-Dichloroethane - rat \\
(inhalation study)
\end{tabular}} & & $7.4(8 \mathrm{mo})$ & & $0.74^{\infty x}$ & & & & Heppel et al., 1946 \\
\hline & short-tailed shrew & & & & 2.09 & 11.0 & 13.9 & & \\
\hline & white-footed mouse & & & & 1.90 & 11.3 & 12.9 & & \\
\hline & cottontail rabbit & & & & 0.52 & 5.9 & 5.3 & & \\
\hline & mink & & & & 0.46 & 7.2 & 4.8 & & \\
\hline & red fox & & & & 0.29 & 5.8 & 3.5 & & \\
\hline & whitetail deer & & & & 0.14 & 4.7 & 2.1 & & \\
\hline
\end{tabular}


Table 12. Toxicological benchmarks for selected mammalian wildlife species

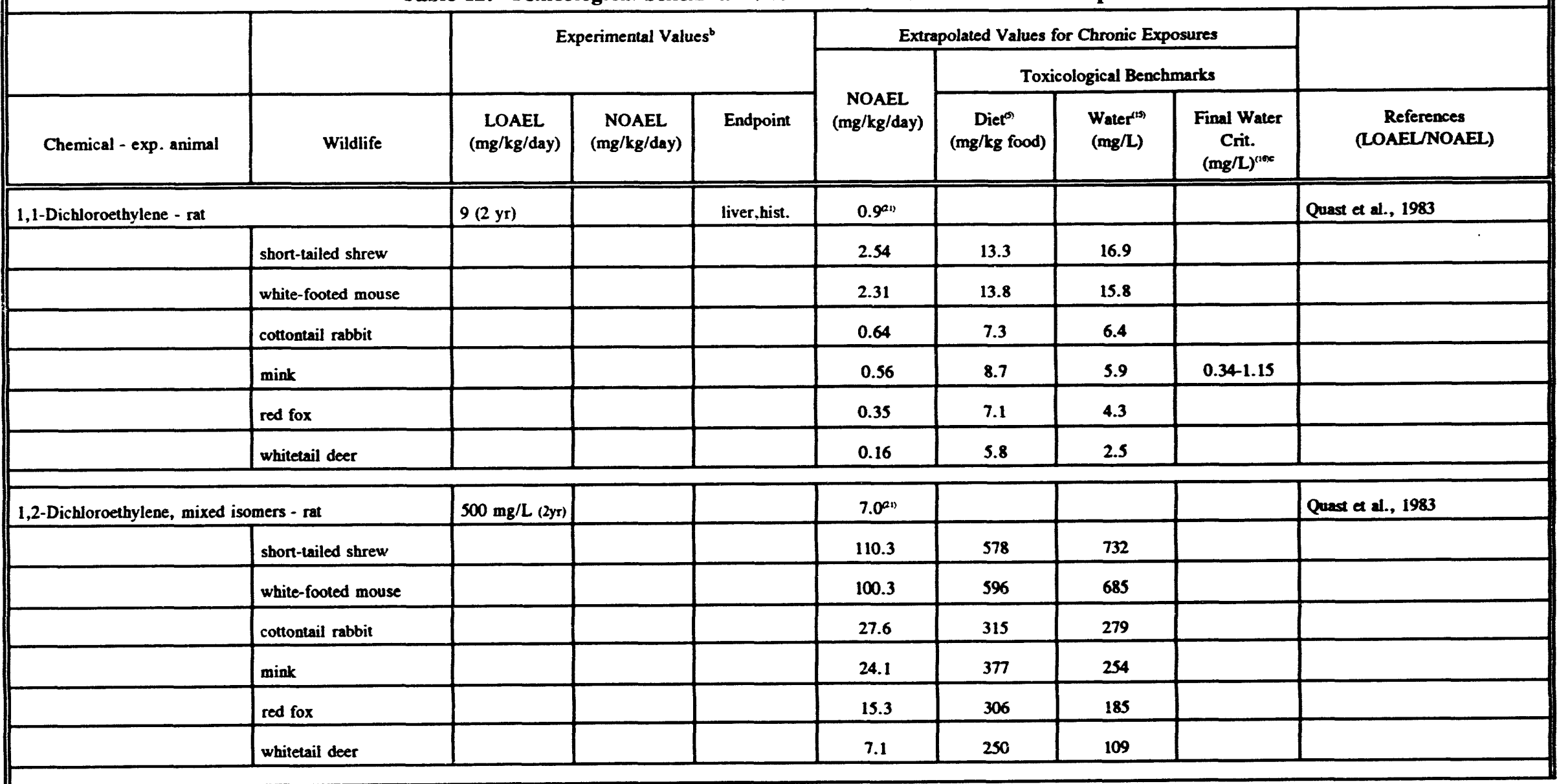




\begin{tabular}{|c|c|c|c|c|c|c|c|c|c|}
\hline \multirow[b]{3}{*}{ Chemical - exp. animal } & \multirow[b]{3}{*}{ Wildife } & \multirow{2}{*}{\multicolumn{3}{|c|}{ Experimental Values ${ }^{\circ}$}} & \multicolumn{4}{|c|}{ Exrrapolated Values for Chronic Exposures } & \multirow[b]{3}{*}{$\begin{array}{c}\text { References } \\
\text { (LOAEL/NOAEL) }\end{array}$} \\
\hline & & & & & \multirow{2}{*}{$\begin{array}{c}\text { NOAELL } \\
(\mathbf{m g} / \mathbf{k g} / \text { day })\end{array}$} & \multicolumn{3}{|c|}{ Toxicological Benchmarks } & \\
\hline & & $\begin{array}{c}\text { LOAEL } \\
(\mathrm{mg} / \mathrm{kg} / \mathrm{day})\end{array}$ & $\underset{(\mathrm{mg} / \mathbf{k g} / \mathrm{day})}{\mathrm{NOAEL}}$ & Endpoint & & 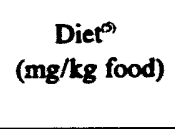 & $\begin{array}{l}\text { Water(') } \\
(m g / L)\end{array}$ & $\begin{array}{c}\text { Final Water } \\
\text { Crit. } \\
(\mathrm{mg} /)^{\text {sioces }}\end{array}$ & \\
\hline \multicolumn{2}{|l|}{ Ehanaol - mouse } & 5500 (gest.) & & & $550^{a p}$ & & & & \\
\hline & short-ailed shrew & & & & 691 & 3626 & 4589 & & \\
\hline & white-footed mouse & & & & 629 & 3738 & 4292 & & \\
\hline \multicolumn{2}{|l|}{ Ethanol - rabbit } & 3.945 (gest.) & & & $394^{40}$ & & & & \\
\hline & cottontail rabbit & & & & 612 & 6993 & 6183 & & \\
\hline & whitetail deer & & & & 159 & 5538 & 2411 & & \\
\hline \multicolumn{2}{|l|}{ Ethanol - dog } & 21,600 (gest.) & & & $2,160^{a 11}$ & & & & \\
\hline & red fox & & & & 2766 & 55384 & 33427 & & \\
\hline & $\operatorname{mink}$ & & & & 4371 & 68375 & 45980 & & \\
\hline \multicolumn{2}{|l|}{ Ethyl acetate - rat } & 3600 (100 dras & 900100 davs & wr. loss & $90^{-29}$ & & & & EPA, 1986e \\
\hline & short-lailed shrew & & & & 255 & 1335 & 1689 & & \\
\hline & white-footed mouse & & & & 231 & 1376 & 1580 & & \\
\hline & cottontail rabbit & & & & 64 & 227 & 643 & & \\
\hline & mink & & & & 56 & 871 & 586 & & \\
\hline & red fox & & & & 35 & 705 & 426 & & \\
\hline & whitetail deer & & & & 16 & 576 & 251 & & \\
\hline
\end{tabular}




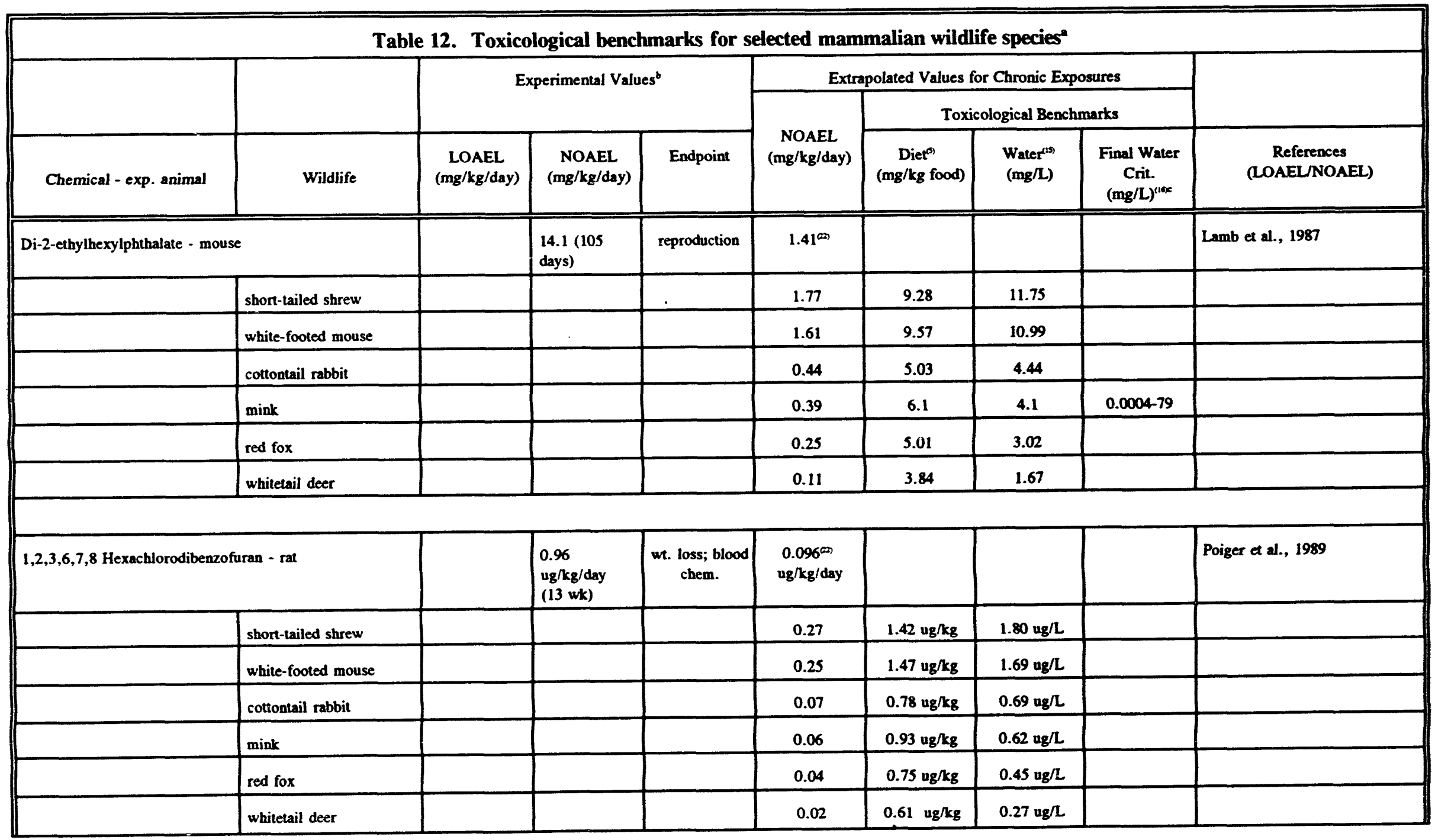




\begin{tabular}{|c|c|c|c|c|c|c|c|c|c|}
\hline \multirow[b]{3}{*}{ Chemical - exp. animal } & \multirow[b]{3}{*}{ Wildlife } & \multirow{2}{*}{\multicolumn{3}{|c|}{ Experimental Values $^{\mathrm{b}}$}} & \multicolumn{4}{|c|}{ Extrapolated Values for Chronic Exposures } & \multirow[b]{3}{*}{$\begin{array}{c}\text { References } \\
\text { (LOAEL/NOAEL }\end{array}$} \\
\hline & & & & & \multirow{2}{*}{$\underset{\text { (mg/kg/day) }}{\text { NOAEL }}$} & \multicolumn{3}{|c|}{ Toxicological Benchmarks } & \\
\hline & & $\begin{array}{c}\text { LOAEL } \\
(\mathrm{mg} / \mathrm{kg} / \mathrm{day})\end{array}$ & $\begin{array}{c}\text { NOAEL } \\
\text { (mg/kg/day) }\end{array}$ & Endpoint & & $\begin{array}{c}\text { Diet? } \\
\text { (mg/kg food) }\end{array}$ & $\begin{array}{l}\text { Water's) } \\
\text { (mg/L) }\end{array}$ & $\begin{array}{c}\text { Final Water } \\
\text { Crit. } \\
(\mathrm{mg} / \mathrm{L})^{(100 \mathrm{C}}\end{array}$ & \\
\hline \multicolumn{2}{|l|}{ Lead acetate - rat } & $50 \mathrm{ppm}(2 \mathrm{yr})$ & $10 \mathrm{ppm}(2 \mathrm{yr})$ & & 0.78 & & & & Azar et al., 1973 \\
\hline & short-railed shrew & & & & 2.21 & 11.57 & 14.64 & & \\
\hline & white-footed mouse & & & & 2.01 & 11.92 & 13.69 & & \\
\hline & cottontail rabbit & & & & 0.55 & 6.30 & 5.57 & & \\
\hline & mink & & & & 0.48 & 7.55 & 5.07 & & \\
\hline & red fox & & & & 0.31 & 6.11 & 3.69 & & \\
\hline & whitetail deer & & & & 0.14 & 4.99 & 2.17 & & \\
\hline \multicolumn{2}{|l|}{ Manganese - human } & & 0.14 & & 0.14 & & & & Schroeder et al., 1966 \\
\hline & short-tailed shrew & & & & 2.27 & 11.93 & 15.10 & & \\
\hline & white-footed mouse & & & & 2.07 & 12.30 & 14.12 & & \\
\hline & cottontail rabbit & & & & 0.57 & 6.50 & 5.75 & & \\
\hline & mink & & & & 0.50 & 7.78 & 5.23 & & \\
\hline & red fox & & & & 0.31 & 6.30 & 3.80 & & \\
\hline & whitetail deer & & & & 0.15 & 5.15 & 2.24 & & \\
\hline
\end{tabular}




\begin{tabular}{|c|c|c|c|c|c|c|c|c|c|}
\hline \multirow[b]{3}{*}{ Chemical - exp. animal } & \multirow[b]{3}{*}{ Wildlife } & \multirow{2}{*}{\multicolumn{3}{|c|}{ Experimental Values ${ }^{b}$}} & \multicolumn{4}{|c|}{ Extrapolated Values for Chronic Exposures } & \multirow[b]{3}{*}{$\begin{array}{c}\text { References } \\
\text { (LOAEL/NOAEL) }\end{array}$} \\
\hline & & & & & \multirow{2}{*}{$\begin{array}{c}\text { NOAEL } \\
(\mathrm{mg} / \mathrm{kg} / \mathrm{day})\end{array}$} & \multicolumn{3}{|c|}{ Toxicological Benchmarks } & \\
\hline & & $\begin{array}{c}\text { LOAEL } \\
(\mathrm{mg} / \mathrm{kg} / \text { day })\end{array}$ & $\begin{array}{c}\text { NOAEL } \\
(\mathbf{m g} / \mathbf{k g} / \text { day })\end{array}$ & Endpoint & & $\begin{array}{c}\text { Diet } \\
\text { (mg/kg food) }\end{array}$ & $\begin{array}{l}\text { Water }{ }^{(1)} \\
(\mathrm{mg} / \mathrm{L})\end{array}$ & $\begin{array}{l}\text { Final Water } \\
\text { Crit. } \\
\text { (mg/L) }\end{array}$ & \\
\hline \multirow[t]{7}{*}{ Mercuric chloride - rat } & & $0.64(39 w k)$ & & $\begin{array}{c}\text { immune syst. } \\
\text { kidney }\end{array}$ & $0.0064^{(-12)}$ & & & & Knoflach et al., 1986 \\
\hline & short-tailed shrew & & & & 0.018 & 0.095 & 0.120 & & \\
\hline & white-footed mouse & & & & 0.016 & 0.098 & 0.112 & & \\
\hline & cottontail rabbit & & & & 0.0045 & 0.052 & 0.046 & & \\
\hline & $\operatorname{mink}$ & & & & 0.0039 & 0.062 & 0.042 & & \\
\hline & red fox & & & & 0.0025 & 0.050 & 0.030 & & \\
\hline & whitetail deer & & & & 0.0012 & 0.041 & 0.018 & & \\
\hline \multirow[t]{7}{*}{ Mercuric sulfide - mouse } & & & 13.3 & & 13.3 & & & & Revis et al., 1989 \\
\hline & short-tailed shrew & & & & 16.7 & 87.68 & 110.96 & & \\
\hline & white-footed mouse & & & & 15.2 & 90.39 & 103.78 & & \\
\hline & cottontail rabbit & & & & 4.2 & 47.77 & 42.23 & & \\
\hline & $\operatorname{mink}$ & & & & 3.7 & 57.21 & 38.47 & & \\
\hline & red fox & & & & 2.3 & 46.34 & 27.97 & & \\
\hline & whitetail deer & & & & 1.1 & 37.83 & 16.47 & & \\
\hline
\end{tabular}




\begin{tabular}{|c|c|c|c|c|c|c|c|c|c|}
\hline \multirow[b]{3}{*}{ Chemical - exp. animal } & \multirow[b]{3}{*}{ Wildife } & \multirow{2}{*}{\multicolumn{3}{|c|}{ Experimental Values $^{b}$}} & \multicolumn{4}{|c|}{ Extrapolated Values for Chronic Exposures } & \multirow[b]{3}{*}{$\begin{array}{c}\text { References } \\
\text { (LOAEL/NOAEL) }\end{array}$} \\
\hline & & & & & \multirow{2}{*}{$\begin{array}{c}\text { NOAEL } \\
(\mathbf{m g} / \mathbf{k g} / \mathrm{day})\end{array}$} & \multicolumn{3}{|c|}{ Toxicological Benchmarks } & \\
\hline & & $\begin{array}{c}\text { LOAEL } \\
\text { (mg/kg/day) }\end{array}$ & $\begin{array}{c}\text { NOAEL } \\
\text { (mg/kg/day) }\end{array}$ & Endpoint & & $\begin{array}{c}D_{i e t^{(s)}} \\
\text { (mg/kg food) }\end{array}$ & $\begin{array}{l}\text { Water's) } \\
(\mathrm{mg} / \mathrm{L})\end{array}$ & $\begin{array}{l}\text { Final Water } \\
\text { Crit. } \\
\text { (mg/L) }\end{array}$ & \\
\hline \multicolumn{2}{|l|}{ Mercury, methyl - rat } & & 0.024 (3 gen) & reproduction & 0.024 & & & & Verschuuren et al., 1976 \\
\hline & shon-tailed shrew & & & & 0.067 & 0.36 & 0.45 & & \\
\hline & white-footed mouse & & & & 0.062 & 0.37 & 0.42 & & \\
\hline & cottentail rabbit & & & & 0.017 & 0.19 & 0.17 & & \\
\hline & whitetail deer & & & & 0.004 & 0.15 & 0.07 & & \\
\hline \multicolumn{2}{|l|}{ Mercury, methyl - mink } & & $0.07(93 \mathrm{~d})$ & w.loss, ataxia & $0.007^{\circ 00}$ & 0.11 & 0.07 & & Wobeser et al., 1975 \\
\hline & red fox & & & & 0.004 & 0.09 & 0.05 & & \\
\hline \multirow[t]{7}{*}{ Methanol - rat } & & $2500(90 \mathrm{~d})$ & $500(90 \mathrm{~d})$ & blood chem. & $50^{m-2}$ & & & & EPA, $1986 f$ \\
\hline & short-tailed shrew & & & & 141 & 741 & 938 & & \\
\hline & white-footed mouse & & & & 129 & 764 & 878 & & \\
\hline & cottontail rabbit & & & & 35 & 404 & 357 & & \\
\hline & mink & & & & 31 & 484 & 325 & 234-297 & \\
\hline & red fox & & & & 20 & 392 & 237 & & \\
\hline & whitetail deer & & & & 9 & 320 & 139 & & \\
\hline
\end{tabular}




\begin{tabular}{|c|c|c|c|c|c|c|c|c|c|}
\hline \multirow[b]{3}{*}{ Chemical - exp. animal } & \multirow[b]{3}{*}{ Wildlife } & \multirow{2}{*}{\multicolumn{3}{|c|}{ Experimental Values $^{b}$}} & \multicolumn{4}{|c|}{ Extrapolated Values for Chronic Exposures } & \multirow[b]{3}{*}{$\begin{array}{c}\text { References } \\
\text { (LOAEL/NOAEL) }\end{array}$} \\
\hline & & & & & \multirow{2}{*}{$\begin{array}{c}\text { NOAEL } \\
\text { (mg/kg/day) }\end{array}$} & \multicolumn{3}{|c|}{ Toxicological Benchmarks } & \\
\hline & & $\begin{array}{c}\text { LOAEL } \\
\left(\mathbf{n}_{\mathbf{G}} / \mathbf{k g} / \text { day) }\right.\end{array}$ & $\begin{array}{c}\text { NOAEL } \\
\text { (mg/kg/day) }\end{array}$ & Endpoint & & $\begin{array}{c}\text { Diet } \\
(\mathrm{mg} / \mathrm{kg} \text { food })\end{array}$ & $\begin{array}{l}\text { Water }{ }^{(19)} \\
(\mathrm{mg} / \mathrm{L})\end{array}$ & $\begin{array}{c}\text { Final Water } \\
\text { Crit. } \\
(\mathrm{mg} / \mathrm{L})^{(10 x}\end{array}$ & \\
\hline \multicolumn{2}{|l|}{ Methylene chloride - rat } & $52.58(2 \mathrm{yr})$ & $5.85(2 \mathrm{yr})$ & $\begin{array}{c}\text { liver; } \\
\text { histology }\end{array}$ & 5.85 & & & & NCA, 1982 \\
\hline & short-tailed shrew & & & & 16.54 & 86.75 & 109.79 & & \\
\hline & white-footed mouse & & & & 15.04 & 89.43 & 102.69 & & \\
\hline & cottontail rabbit & & & & 4.137 & 47.27 & 41.79 & & \\
\hline & mink & & & & 3.62 & 56.61 & 38.07 & $0.69-8.7$ & \\
\hline & red fox & & & & 2.29 & 45.85 & 27.68 & & \\
\hline & whitetail deer & & & & 1.07 & 37.43 & 16.30 & & \\
\hline \multicolumn{2}{|c|}{ Methyl ethyl ketone - rat (inhalation data) } & & 92 (12 wk) & & $9.2^{\infty m}$ & & & & Labelle and Brieger, 1955 \\
\hline & short-tailed shrew & & & & 26 & 136.4 & 172.7 & & \\
\hline & white-footed mouse & & & & 23.7 & 140.6 & 161.5 & & \\
\hline & cottontail rabbit & & & & 6.5 & 74.3 & 65.7 & & \\
\hline & $\operatorname{mink}$ & & & & 5.7 & 89.0 & 59.9 & $25.5-56.0$ & \\
\hline & red fox & & & & 3.6 & 72.1 & 43.5 & & \\
\hline & whitetail deer & & & & 1.7 & 58.9 & 25.6 & & \\
\hline
\end{tabular}




\begin{tabular}{|c|c|c|c|c|c|c|c|c|c|}
\hline \multirow[b]{3}{*}{ Chemical - exp. animal } & \multirow[b]{3}{*}{ Wildlife } & \multirow{2}{*}{\multicolumn{3}{|c|}{ Experimental Values $^{b}$}} & \multicolumn{4}{|c|}{ Extrapolated Values for Chronic Exposures } & \multirow[b]{3}{*}{$\begin{array}{c}\text { References } \\
\text { (LOAEL/NOAEL) }\end{array}$} \\
\hline & & & & & \multirow{2}{*}{$\underset{(\mathrm{mg} / \mathrm{kg} / \mathrm{day})}{\mathrm{NOAEL}}$} & \multicolumn{3}{|c|}{ Toxicological Benchmarks } & \\
\hline & & $\underset{\text { (mg/kg/day) }}{\text { LOAEL }}$ & $\underset{(\mathrm{mg} / \mathrm{kg} / \mathrm{day})}{\mathrm{NOAEL}}$ & Endpoint & & $\begin{array}{c}\operatorname{Diet}^{(5)} \\
\text { (mg/kg food) }\end{array}$ & $\begin{array}{l}\text { Water }(19) \\
(\mathbf{m g} / \mathrm{L})\end{array}$ & $\begin{array}{c}\text { Final Water } \\
\text { Crit. } \\
(\mathrm{mg} / \mathrm{L})^{\operatorname{cose}}\end{array}$ & \\
\hline \multicolumn{2}{|c|}{$\begin{array}{l}\text { 4-Methyl-2-pentanone (methyl isobutyl ketone) } \\
\text { - rat }\end{array}$} & & 50 (13 wk) & liver, kidney & $5^{(22)}$ & & & & $\begin{array}{l}\text { Microbiological Associates, } \\
1986\end{array}$ \\
\hline & short-tailed shrew & & & & 14.1 & 74 & 94 & & \\
\hline & white-footed mouse & & & & 12.9 & 76 & 88 & & \\
\hline & cottontail rabbit & & & & 3.6 & 40 & 36 & & \\
\hline & mink & & & & 3.1 & 48 & 33 & $12.1-12.4$ & \\
\hline & red fox & & & & 1.9 & 39 & 24 & & \\
\hline & whitetail deer & & & & 0.9 & 32 & 14 & & \\
\hline \multicolumn{2}{|l|}{ Nickel sulphate - rat } & & 24.15 (3 gen) & reproduction & 24.15 & & & & Ambrose et al., 1976 \\
\hline & short-tailed shrew & & & & 68.29 & 358 & 453 & & \\
\hline & white-footed mouse & & & & 62.10 & 369 & 424 & & \\
\hline & cottontail rabbit & & & & 17.08 & 195 & 173 & & \\
\hline & mink & & & & 14.94 & 234 & 158 & & \\
\hline & red fox & & & & 9.46 & 189 & 114 & & \\
\hline & whitetail deer & & & & 4.42 & 155 & 67 & & \\
\hline
\end{tabular}




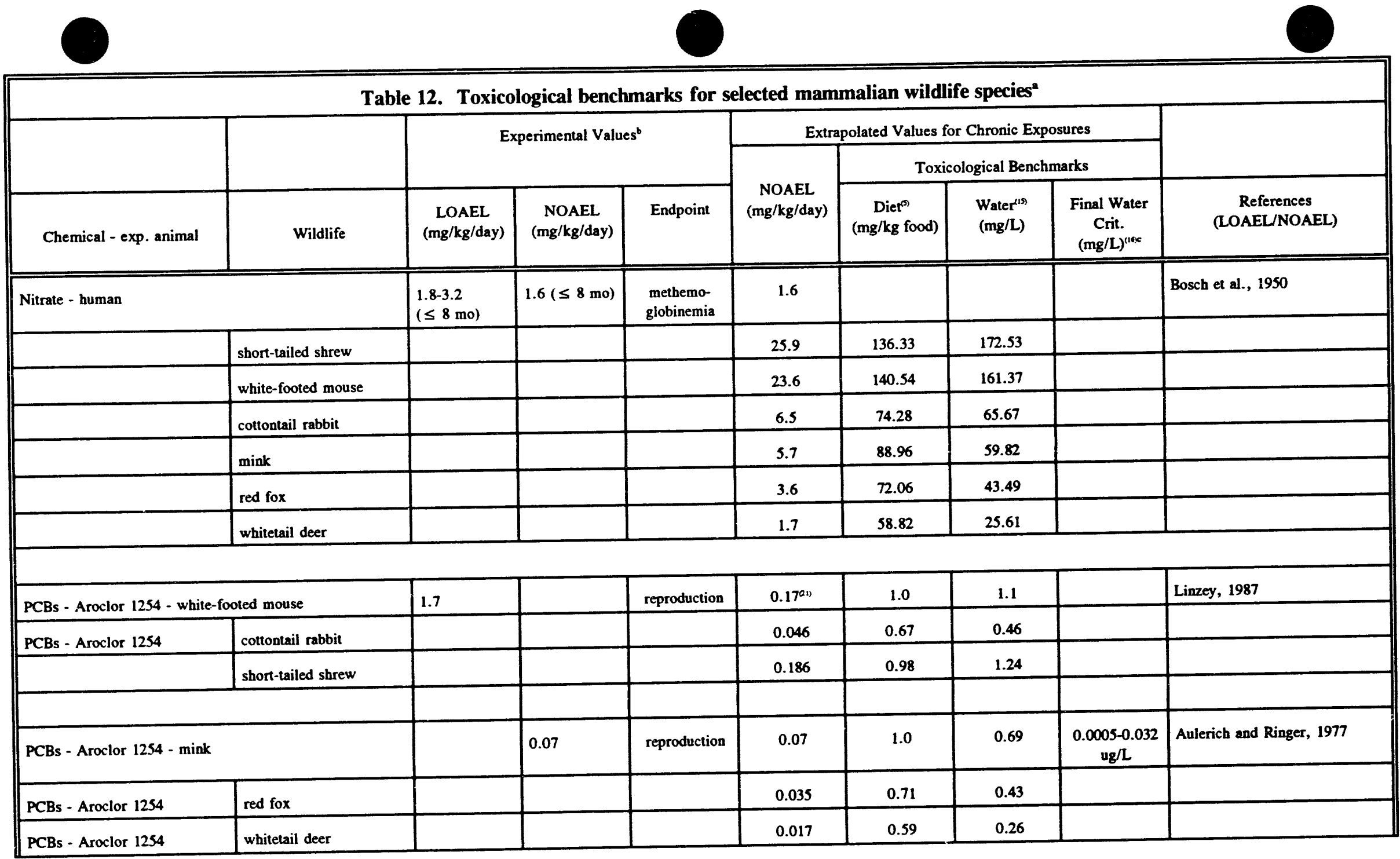




\begin{tabular}{|c|c|c|c|c|c|c|c|c|c|}
\hline \multirow[b]{3}{*}{ Chemical - exp. animal } & \multirow[b]{3}{*}{ Wildlife } & \multirow{2}{*}{\multicolumn{3}{|c|}{ Experimental Values ${ }^{b}$}} & \multicolumn{4}{|c|}{ Extrapolated Values for Chronic Exposures } & \multirow[b]{3}{*}{$\begin{array}{c}\text { References } \\
\text { (LOAEL/NOAEL) }\end{array}$} \\
\hline & & & & & \multirow{2}{*}{$\begin{array}{c}\text { NOAEL } \\
\text { (mg/kg/day) }\end{array}$} & \multicolumn{3}{|c|}{ Toxicological Benchmarks } & \\
\hline & & $\underset{(\mathrm{mg} / \mathbf{k g} / \mathrm{day})}{\text { LOAEL }}$ & $\underset{(\mathbf{m g} / \mathbf{k g} / \text { day) }}{\text { NOAEL }}$ & Endpoint & & $\underset{(\mathrm{mg} / \mathrm{kg} \text { food) }}{\mathrm{Dier}^{()}}$ & $\begin{array}{l}\text { Water(1) } \\
(\mathrm{mg} / \mathrm{L})\end{array}$ & $\begin{array}{c}\text { Final Water } \\
\text { Crit. } \\
(\mathrm{mg} / \mathrm{L})^{\operatorname{loc}} \\
\end{array}$ & \\
\hline \multicolumn{2}{|c|}{$2,3,4,7,8$ - Pentachlorodibenzofuran - rat } & & $\begin{array}{l}0.096 \mathrm{ug} / \mathrm{kg} / \mathrm{d} \\
(13 \mathrm{wk})\end{array}$ & $\begin{array}{l}\text { wt. loss } \\
\text { blood chem. }\end{array}$ & $\begin{array}{l}0.0096^{(2)} \\
\text { ug/kg/day }\end{array}$ & & & & Poiger et al., 1989 \\
\hline & shor-tailed shrew & & & & 0.027 & $0.142 \mathrm{ug} / \mathrm{kg}$ & $0.180 \mathrm{ug} / \mathrm{L}$ & & \\
\hline & white-footed mouse & & & & 0.025 & $0.147 \mathrm{ug} / \mathrm{kg}$ & $0.169 \mathrm{ug} / \mathrm{h}$ & & \\
\hline & cottontail rabbit & & & & 0.007 & $0.078 \mathrm{ug} / \mathrm{kg}$ & $0.069 \mathrm{ug} / \mathrm{L}$ & & \\
\hline & mink & & & & 0.006 & $0.093 \mathrm{ug} / \mathrm{kg}$ & $0.062 \mathrm{ug} / \mathrm{L}$ & & \\
\hline & red fox & & & & 0.0038 & $0.075 \mathrm{ug} / \mathrm{kg}$ & $0.045 \mathrm{ug} / \mathrm{L}$ & & \\
\hline & whitetail deer & & & & 0.0018 & $0.062 \mathrm{ug} / \mathrm{kg}$ & $0.027 \mathrm{ug} / \mathrm{L}$ & & \\
\hline \multicolumn{2}{|c|}{$1,2,3,4,8$ - Pentachlorodibenzofuran - rat } & & $\begin{array}{l}290 \mathrm{ug} / \mathrm{kg} / \mathrm{day} \\
(13 \mathrm{wk})\end{array}$ & $\begin{array}{c}\text { wt. loss } \\
\text { blood chem. }\end{array}$ & $\begin{array}{c}29^{\infty 0 m} \\
\mathrm{ug} / \mathrm{kg} / \mathrm{day}\end{array}$ & & & & \\
\hline & shor-tailed shrew & & & & 81.9 & $429 \mathrm{ug} / \mathrm{kg}$ & $544 \mathrm{ug} / \mathrm{L}$ & & Poiger et al., 1989 \\
\hline & white-footed mouse & & & & 74.5 & $443 \mathrm{ug} / \mathrm{kg}$ & $509 \mathrm{ug} / \mathrm{L}$ & & \\
\hline & cottontail rabbit & & & & 20.5 & $234 \mathrm{ug} / \mathrm{kg}$ & $207 \mathrm{ug} / \mathrm{L}$ & & \\
\hline & mink & & & & 17.9 & $280 \mathrm{ug} / \mathrm{kg}$ & $189 \mathrm{ug} / \mathrm{L}$ & & \\
\hline & red fox & & & & 11.3 & $227 \mathrm{ug} / \mathrm{kg}$ & $137 \mathrm{ug} / \mathrm{L}$ & & \\
\hline & whitetail deer & & & & 5.3 & $185 \mathrm{ug} / \mathrm{kg}$ & $81 \mathrm{ug} / \mathrm{L}$ & & \\
\hline
\end{tabular}




\begin{tabular}{|c|c|c|c|c|c|c|c|c|c|}
\hline \multirow[b]{3}{*}{ Chemical - exp. animal } & \multirow[b]{3}{*}{ Wildlife } & \multirow{2}{*}{\multicolumn{3}{|c|}{ Experimental Values ${ }^{\mathrm{b}}$}} & \multicolumn{4}{|c|}{ Extrapolated Values for Chronic Exposures } & \multirow[b]{3}{*}{$\begin{array}{c}\text { References } \\
\text { (LOAEL/NOAEL) }\end{array}$} \\
\hline & & & & & \multirow{2}{*}{$\begin{array}{c}\text { NOAEL } \\
\text { (mg/kg/day) }\end{array}$} & \multicolumn{3}{|c|}{ Toxicological Benchmarks } & \\
\hline & & $\underset{(\mathrm{mg} / \mathrm{kg} / \mathrm{day})}{\text { LOAEL }}$ & $\begin{array}{c}\text { NOAEL } \\
(\mathbf{m g} / \mathbf{k g} / \mathrm{day})\end{array}$ & Endpoint & & $\begin{array}{c}\text { Diet }^{(0)} \\
\text { (mg/kg food) }\end{array}$ & $\begin{array}{l}\text { Water }{ }^{19} \\
(\mathrm{mg} / \mathrm{L})\end{array}$ & $\begin{array}{c}\text { Final Water } \\
\text { Crit. } \\
(\mathrm{mg} / \mathrm{L})^{100 x} \\
\end{array}$ & \\
\hline \multicolumn{2}{|c|}{$1,2,3,7,8$ - Pentachlorodibenzofuran - rat } & & \begin{tabular}{|l}
0.96 \\
$\mathrm{ug} / \mathrm{kg} / \mathrm{day}$ \\
$(13 \mathrm{wk})$ \\
\end{tabular} & $\begin{array}{l}\text { wr. loss } \\
\text { blood chem. }\end{array}$ & $\begin{array}{c}0.096^{(2)} \\
\text { ug/kg/day }\end{array}$ & & & & Poiger et al., 1989 \\
\hline & short-tailed shrew & & & & 0.27 & $1.42 \mathrm{ug} / \mathrm{kg}$ & $1.80 \mathrm{ug} / \mathrm{L}$ & & \\
\hline & white-footed mouse & & & & 0.25 & $1.47 \mathrm{ug} / \mathrm{kg}$ & $1.69 \mathrm{ug} / \mathrm{L}$ & & \\
\hline & cottontail rabbit & & & & 0.068 & $0.77 \mathrm{ug} / \mathrm{kg}$ & $0.69 \mathrm{ug} / \mathrm{L}$ & & \\
\hline & mink & & & & 0.059 & $0.93 \mathrm{ug} / \mathrm{kg}$ & $0.62 \mathrm{ug} / \mathrm{L}$ & & \\
\hline & red fox & & & & 0.038 & $0.75 \mathrm{ug} / \mathrm{kg}$ & $0.45 \mathrm{ug} / \mathrm{L}$ & & \\
\hline & whitetail deer & & & & 0.018 & $0.61 \mathrm{ug} / \mathrm{kg}$ & $0.27 \mathrm{ug} / \mathrm{L}$ & & \\
\hline \multicolumn{2}{|l|}{ Selenium (as selenate) - mouse } & 0.57 & & reproduction & $0.057^{(21)}$ & & & & Schroeder and Mitchner, 1971 \\
\hline & short-tailed shrew & & & & 0.07 & 0.38 & 0.48 & & \\
\hline & white-footed mouse & & & & 0.065 & 0.39 & 0.44 & & \\
\hline & contontail rabbit & & & & 0.018 & 0.20 & 0.18 & & \\
\hline & mink & & & & 0.016 & 0.25 & 0.16 & & \\
\hline & red fox & & & & 0.01 & 0.20 & 0.12 & & \\
\hline & whitetail deer & & & & 0.005 & 0.16 & 0.07 & & \\
\hline
\end{tabular}




\begin{tabular}{|c|c|c|c|c|c|c|c|c|c|}
\hline \multirow[b]{3}{*}{ Chemical - exp. animal } & \multirow[b]{3}{*}{ Wildlife } & \multirow{2}{*}{\multicolumn{3}{|c|}{ Experimental Values ${ }^{b}$}} & \multicolumn{4}{|c|}{ Extrapolated Values for Chronic Exposures } & \multirow[b]{3}{*}{$\begin{array}{c}\text { References } \\
\text { (LOAEL/NOAEL) }\end{array}$} \\
\hline & & & & & \multirow{2}{*}{$\begin{array}{c}\text { NOAEL } \\
\text { (mg/kg/day) }\end{array}$} & \multicolumn{3}{|c|}{ Toxicological Benchmarks } & \\
\hline & & $\underset{\text { (mg/kg/day) }}{\text { LOAEL }}$ & $\begin{array}{c}\text { NOAEL } \\
(\mathbf{m g} / \mathbf{k g} / \text { day })\end{array}$ & Endpoint & & $\begin{array}{c}\text { Dier(s) } \\
\text { (mg/kg food) }\end{array}$ & $\begin{array}{l}\text { Water'(1) } \\
(\mathrm{mg} / \mathrm{L})\end{array}$ & $\begin{array}{c}\text { Final Water } \\
\text { Crit. } \\
(\mathrm{mg} / \mathrm{L})^{\cos } \\
\end{array}$ & \\
\hline \multicolumn{2}{|l|}{ Strontium (stable) - rat } & & $263.1(3 \mathrm{yr})$ & $\begin{array}{l}\text { rachitic } \\
\text { changes }\end{array}$ & 263.1 & & & & Skoryna, 1981 \\
\hline & short-tailed shrew & & & & 743 & 3901 & 4938 & & \\
\hline & white-footed mouse & & & & 677 & 4022 & 4618 & & \\
\hline & cottontail rabbit & & & & 186 & 2126 & 1879 & & \\
\hline & mink & & & & 163 & 2546 & 1712 & & \\
\hline & red fox & & & & 103 & 2062 & 1245 & & \\
\hline & whitetail deer & & & & 48 & 1683 & 733 & & \\
\hline \multirow[t]{7}{*}{$2,3,7,8-\mathrm{TCDD}$ - rat } & & & \begin{tabular}{|l}
0.001 \\
ug/kg/day \\
$(3$ gen $)$ \\
\end{tabular} & reproduction & $\begin{array}{c}0.001 \\
u g / \mathrm{kg} / \mathrm{day}\end{array}$ & & & & Murray et al., 1979 \\
\hline & short-tailed shrew & & & & 0.0028 & $0.0148 \mathrm{ug} / \mathrm{kg}$ & $0.0188 \mathrm{ug} / \mathrm{L}$ & & \\
\hline & white-footed mouse & & & & 0.0026 & $0.0153 \mathrm{ug} / \mathrm{kg}$ & $0.0175 \mathrm{ug} / \mathrm{L}$ & & \\
\hline & cottontail rabbit & & & & 0.0007 & $0.0081 \mathrm{ug} / \mathrm{kg}$ & $0.0072 \mathrm{ug} / \mathrm{L}$ & & \\
\hline & mink & & & & 0.0006 & $0.0097 \mathrm{ug} / \mathrm{kg}$ & $0.0065 \mathrm{ug} / \mathrm{L}$ & $\begin{array}{c}0.002- \\
0.012 \mathrm{pg} / \mathrm{L}\end{array}$ & \\
\hline & red fox & & & & 0.0004 & $0.0078 \mathrm{ug} / \mathrm{kg}$ & $0.0047 \mathrm{ug} / \mathrm{L}$ & & \\
\hline & whitetail deer & & & & 0.00018 & $0.0063 \mathrm{ug} / \mathrm{kg}$ & $0.0027 \mathrm{ug} / \mathrm{L}$ & & \\
\hline
\end{tabular}




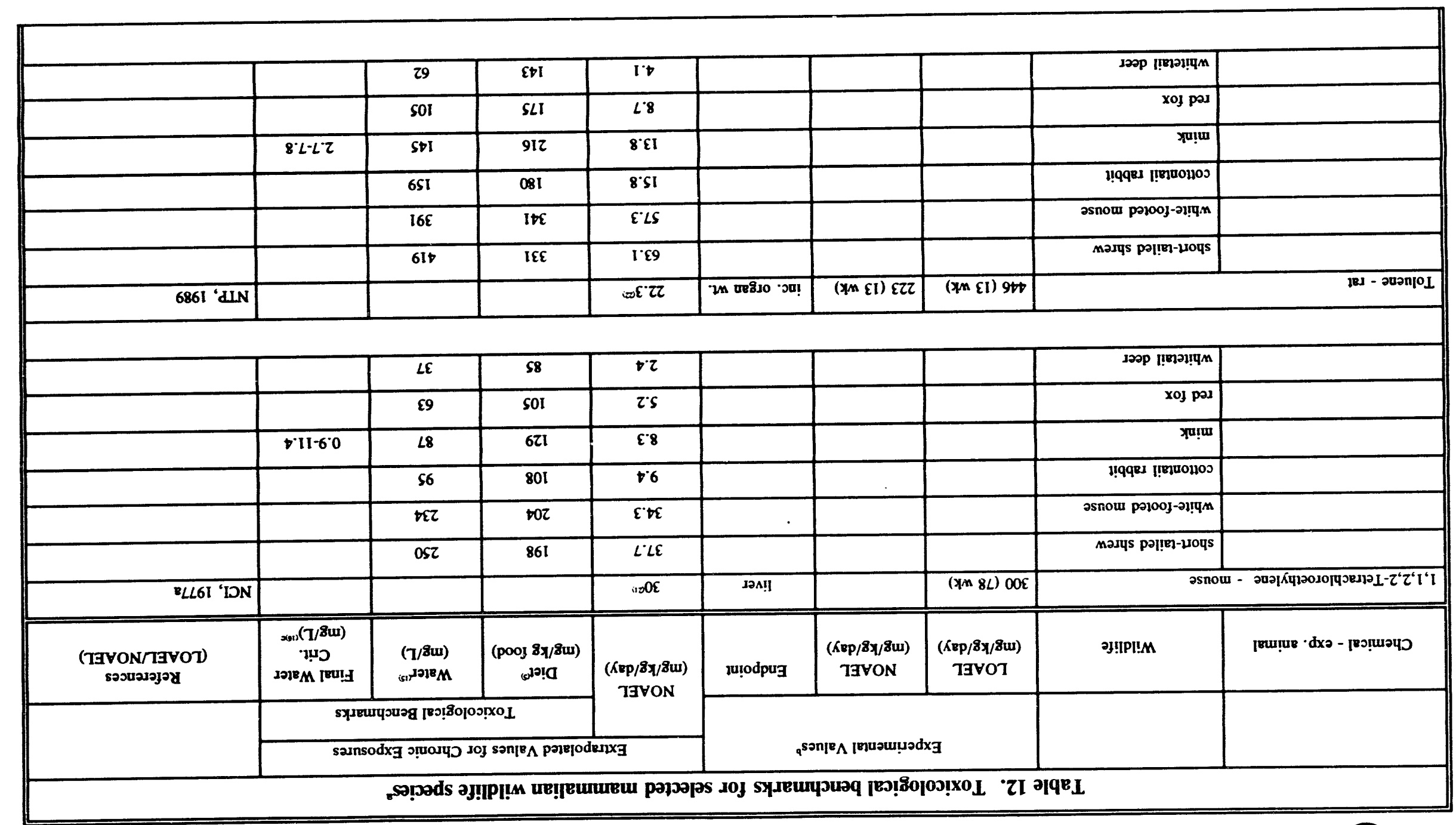




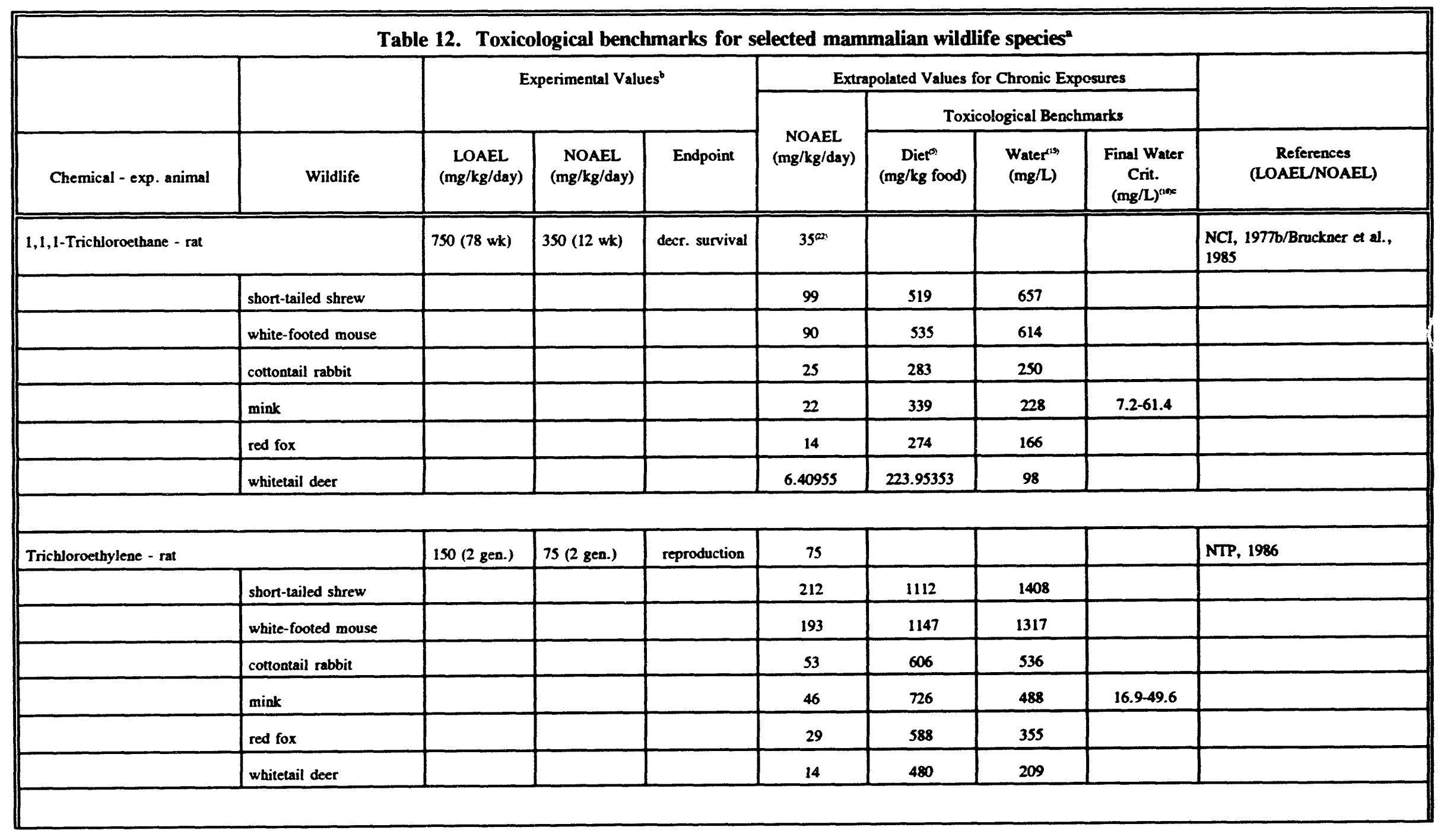




\begin{tabular}{|c|c|c|c|c|c|c|c|c|c|}
\hline \multirow[b]{3}{*}{ Chemical - exp. animal } & \multirow[b]{3}{*}{ Wildlife } & \multirow{2}{*}{\multicolumn{3}{|c|}{ Experimental Values' }} & \multicolumn{4}{|c|}{ Extrapolated Values for Chronic Exposures } & \multirow[b]{3}{*}{$\begin{array}{c}\text { References } \\
\text { (LOAEL/NOAEL) }\end{array}$} \\
\hline & & & & & \multirow{2}{*}{$\begin{array}{c}\text { NOAEL } \\
\text { (mg/kg/day) }\end{array}$} & \multicolumn{3}{|c|}{ Toxicological Benchmarks } & \\
\hline & & $\underset{\text { (mg/kg/day) }}{\text { LOAEL }}$ & $\underset{(\mathrm{mg} / \mathrm{kg} / \mathrm{day})}{\mathrm{NOAEL}}$ & Endpoint & & $\begin{array}{c}\text { Diet? } \\
\text { (mg/kg food) }\end{array}$ & $\begin{array}{l}\text { Water's) } \\
\text { (mg/L) }\end{array}$ & $\begin{array}{c}\text { Final Water } \\
\text { Crit. } \\
(\mathrm{mg} / \mathrm{L})^{\operatorname{anoc}}\end{array}$ & \\
\hline \multicolumn{2}{|l|}{ Uranium (soluble salts) - rabbit } & 2.8 (30 days) & & kidney, hist. & $0.28^{a 11}$ & & & & Maynard and Hodge, 1949 \\
\hline & short-tailed shrew & & & & 1.74 & 9.12 & 11.54 & & \\
\hline & white-footed mouse & & & & 1.58 & 9.40 & 10.80 & & \\
\hline & cottontail rabbit & & & & 0.44 & 4.97 & 4.39 & & \\
\hline & $\operatorname{mink}$ & & & & 0.38 & 5.95 & 4.00 & & \\
\hline & red fox & & & & 0.24 & 4.82 & 2.90 & & \\
\hline & whitetail deer & & & & 0.11 & 3.94 & 1.71 & & \\
\hline \multirow[t]{7}{*}{ Vinyl chloride - rat } & & 1.3 (149wk) & 0.13 (149 wk) & $\begin{array}{l}\text { decr. survival } \\
\text { liver }\end{array}$ & 0.13 & & & & Dow Chemical Co., 1984 \\
\hline & short-tailed shrew & & & & 0.37 & 1.93 & 2.44 & & \\
\hline & white-footed mouse & & & & 0.33 & 1.99 & 2.28 & & \\
\hline & cottontail rabbit & & & & 0.09 & 1.05 & 0.93 & & \\
\hline & mink & & & & 0.08 & 1.26 & 0.85 & $\begin{array}{c}0.002-0.9 \\
\mu \& / L\end{array}$ & \\
\hline & red fox & & & & 0.05 & 1.02 & 0.62 & & \\
\hline & whitetail deer & & & & 0.02 & 0.83 & 0.36 & & \\
\hline
\end{tabular}




\begin{tabular}{|c|c|c|c|c|c|c|c|c|c|}
\hline \multirow[b]{3}{*}{ Chemical - exp. animal } & \multirow[b]{3}{*}{ Wildlife } & \multirow{2}{*}{\multicolumn{3}{|c|}{ Experimental Values' }} & \multicolumn{4}{|c|}{ Extrapolated Values for Chronic Exposures } & \multirow[b]{3}{*}{$\begin{array}{c}\text { References } \\
\text { (LOAEL/NOAEL) }\end{array}$} \\
\hline & & & & & \multirow{2}{*}{$\begin{array}{c}\text { NOAEL } \\
(\mathbf{m g} / \mathbf{k g} / \mathrm{day})\end{array}$} & \multicolumn{3}{|c|}{ Toxicological Benchmarks } & \\
\hline & & $\underset{(\mathrm{mg} / \mathrm{kg} / \mathrm{day})}{\text { LOAEL }}$ & $\underset{\text { (mg/kg/day) }}{\text { NOAEL }}$ & Endpoint & & $\begin{array}{c}\text { Diers) } \\
\text { (mg/kg food) }\end{array}$ & $\begin{array}{l}\text { Water } \\
(\mathrm{mg} / \mathrm{L})\end{array}$ & $\begin{array}{c}\text { Final Water } \\
\text { Crit. } \\
(\mathrm{mg} / \mathrm{L})^{\text {nox }}\end{array}$ & \\
\hline \multicolumn{2}{|l|}{ Mixed xylenes - rat } & & 500 (103 wk) & reproduction & 500 & & & & ATSDR, 19906 \\
\hline & short-tailed shrew & & & & 1414 & 7415 & 9384 & & \\
\hline & white-footed mouse & & & & 1286 & 7644 & 8777 & & \\
\hline & cottontail rabbit & & & & 354 & 4040 & 3572 & & \\
\hline & $\operatorname{mink}$ & & & & 310 & 4839 & 3254 & 570 & \\
\hline & red fox & & & & 196 & 3920 & 2366 & & \\
\hline & whitetail deer & & & & 92 & 3200 & 1393 & & \\
\hline \multicolumn{2}{|l|}{ Zinc carbonate - rat } & & 97 (37 days) & reproduction & $9.7 \mathrm{~m}$ & & & & Kinmamon, 1963 \\
\hline & short-tailed shrew & & & & 27.4 & 144 & 182 & & \\
\hline & white-footed mouse & & & & 24.9 & 148 & 170 & & \\
\hline & cottontail rabbit & & & & 6.9 & 78 & 69 & & \\
\hline & mink & & & & 6.0 & 94 & 63 & & \\
\hline & red fox & & & & 3.8 & 76 & 46 & & \\
\hline & whitetail deer & & & & 1.8 & 62 & 27 & & \\
\hline
\end{tabular}




\begin{tabular}{|c|c|c|c|c|c|c|c|c|c|}
\hline \multirow[b]{3}{*}{ Chemical - exp. animal } & \multirow[b]{3}{*}{ Wildlife } & \multirow{2}{*}{\multicolumn{3}{|c|}{ Experimental Values ${ }^{b}$}} & \multicolumn{4}{|c|}{ Extrapolated Values for Chronic Exposures } & \multirow[b]{3}{*}{$\begin{array}{c}\text { References } \\
\text { (LOAEL NOAEL) }\end{array}$} \\
\hline & & & & & \multirow{2}{*}{$\begin{array}{c}\text { NOAEL } \\
(\mathrm{mg} / \mathrm{kg} / \mathrm{day})\end{array}$} & \multicolumn{3}{|c|}{ Toxicological Benchmarks } & \\
\hline & & $\underset{\text { (mg/kg/day) }}{\text { LOAEL }}$ & $\underset{(\mathrm{mg} / \mathbf{k g} / \mathrm{day})}{\mathrm{NOAEL}}$ & Endpoint & & $\begin{array}{c}\text { Dief } \\
\text { (mg/kg food) }\end{array}$ & $\begin{array}{l}\text { Water's) } \\
(\mathrm{mg} / \mathrm{L})\end{array}$ & $\begin{array}{c}\text { Final Water } \\
\text { Crit. } \\
(\mathrm{mg} / \mathrm{L})^{\text {inot }}\end{array}$ & \\
\hline \multicolumn{2}{|l|}{ Zirconium sulphate - mouse } & 0.7 (lifetime) & & longevity & $0.07^{a 11}$ & & & & Schrocder et al., 1968 \\
\hline & short-tailed shrew & & & & 0.09 & 0.46 & 0.58 & & \\
\hline & white-footed mouse & & & & 0.08 & 0.48 & 0.55 & & \\
\hline & cottontail rabbit & & & & 0.02 & 0.25 & 0.22 & & \\
\hline & mink & & & & 0.019 & 0.30 & 0.20 & & \\
\hline & red fox & & & & 0.012 & 0.24 & 0.15 & & \\
\hline & whitetail deer & & & & 0.006 & 0.20 & 0.09 & & \\
\hline
\end{tabular}

- Numbers in parentheses refer 10 equations in lext.

- Dieury concentration in ppm; water concentration in mg/L.

- Calculated from Equation 16 using FCM values ginen in Table 8 and log P and BCF values given in Table 10. 


\begin{tabular}{|c|c|c|c|c|c|c|c|c|c|}
\hline \multirow[b]{3}{*}{ Chemical - exp. animal } & \multirow[b]{3}{*}{ Wildlife } & \multirow{2}{*}{\multicolumn{3}{|c|}{ Experimental Values }} & \multicolumn{4}{|c|}{ Extrapolated Values for Chronic Exposures } & \multirow[b]{3}{*}{$\begin{array}{c}\text { References } \\
\text { (LOAEL/NOAEL) }\end{array}$} \\
\hline & & & & & \multirow{2}{*}{$\begin{array}{c}\text { NOAEL } \\
\text { (mg/kg/day) }\end{array}$} & \multicolumn{3}{|c|}{ Toxicological Benchmarks } & \\
\hline & & $\underset{\text { (mg/kg/day) }}{\text { LOAEL }}$ & $\underset{\text { (mg/kg/day) }}{\text { NOAEL }}$ & Endpoint & & $\begin{array}{c}\text { Diet } \\
\text { (mg/kg food) }\end{array}$ & $\begin{array}{l}\text { Water }{ }^{\text {(1) }} \\
(\mathrm{mg} / \mathrm{L})\end{array}$ & $\begin{array}{c}\text { Final Water } \\
\text { Crit. } \\
(\mathrm{mg} / \mathrm{L})^{\text {aine }}\end{array}$ & \\
\hline \multicolumn{2}{|c|}{ Chlordane - redwinged blackbird } & & 2.13 ( 8.4 days) & mortaity & 2.13 & & & & \\
\hline & American Robin & & & & 2.11 & 9.7 & 14.6 & & Stickel et al., 1983 \\
\hline & Woodcock & & & & 1.47 & 14.3 & 14.6 & & \\
\hline & Wild Turkey & & & & 0.48 & 15.3 & 14.6 & & \\
\hline & Belted Kingfisher & & & & 1.62 & 14.3 & 14.6 & $0.17 \mathrm{ug} / \mathrm{L}$ & \\
\hline & Great Blue Heron & & & & 0.64 & 15.0 & 14.6 & 0.17 ug $/ \mathrm{L}$ & \\
\hline & Barred Owl & & & & 0.96 & 14.7 & 14.6 & & \\
\hline & Cooper's Hawk & & & & 1.13 & 14.6 & 14.6 & & \\
\hline & Red-Tailed Hawk & & & & 0.83 & 14.8 & 14.6 & & \\
\hline \multicolumn{2}{|c|}{ Chrome alum $\left(\mathrm{CrK}\left(\mathrm{SO}_{4}\right)_{2}\right.$ - black duck } & & $2.7 \quad(10 \mathrm{mo})$ & reproduction & 2.7 & & & & Haseltine at al., unpubl. data \\
\hline & American Robin & & & & 6.77 & 32.66 & 49.25 & & (from Eisler, 1986) \\
\hline & Woodcock & & & & 4.96 & 48.47 & 49.25 & & \\
\hline & Wild Turkey & & & & 1.63 & 51.67 & 49.26 & & \\
\hline & Belted King fisher & & & & 5.46 & 48.18 & 49.27 & & \\
\hline & Great Blue Heron & & & & 2.18 & 50.82 & 49.26 & & \\
\hline & Barred Owi & & & & 3.24 & 49.66 & 49.26 & & \\
\hline & Cooper's Hawk & & & & 3.81 & 49.19 & 49.25 & & \\
\hline & Red-Tailed Hawk & & & & 2.79 & 50.09 & 49.26 & & \\
\hline
\end{tabular}




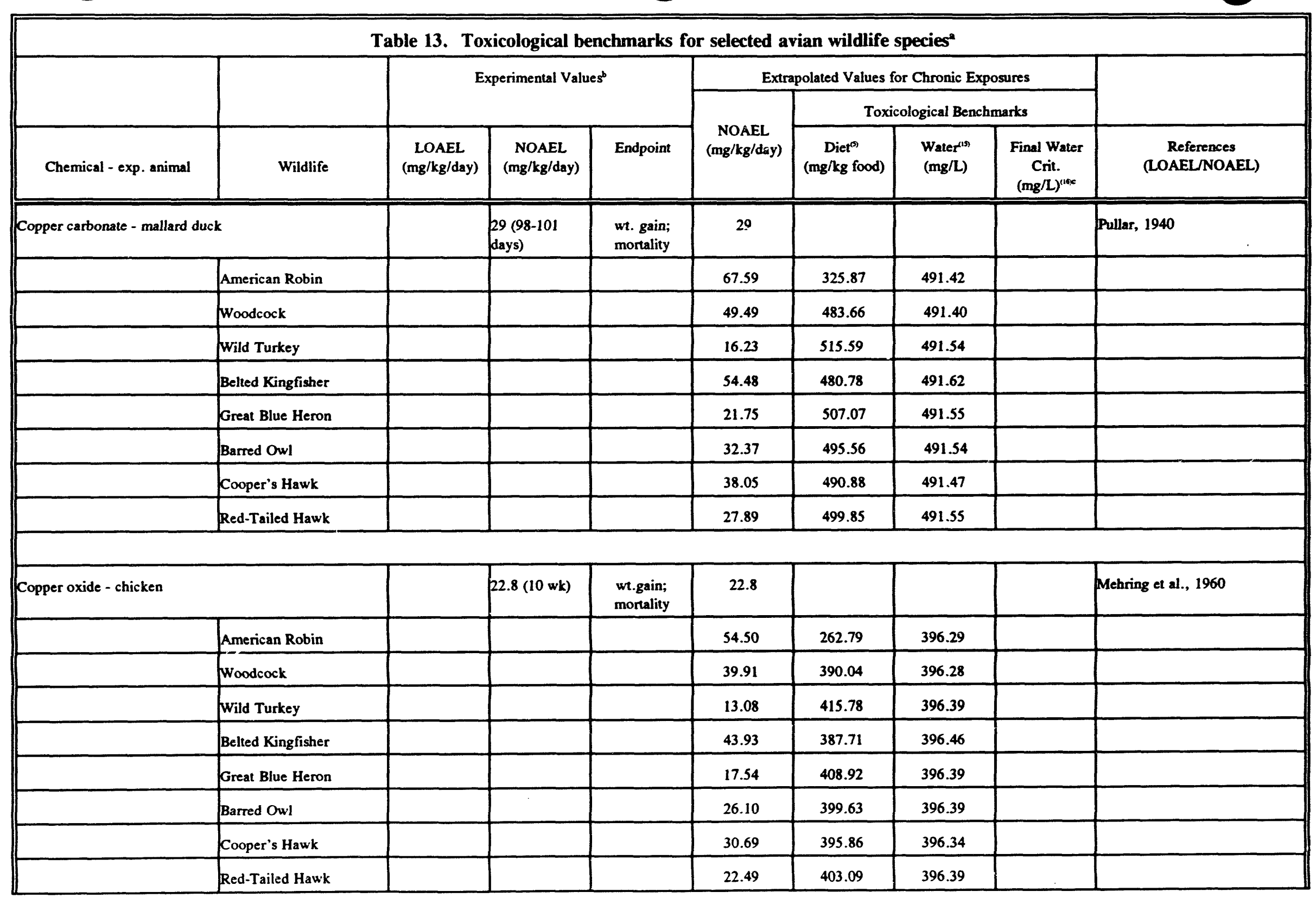




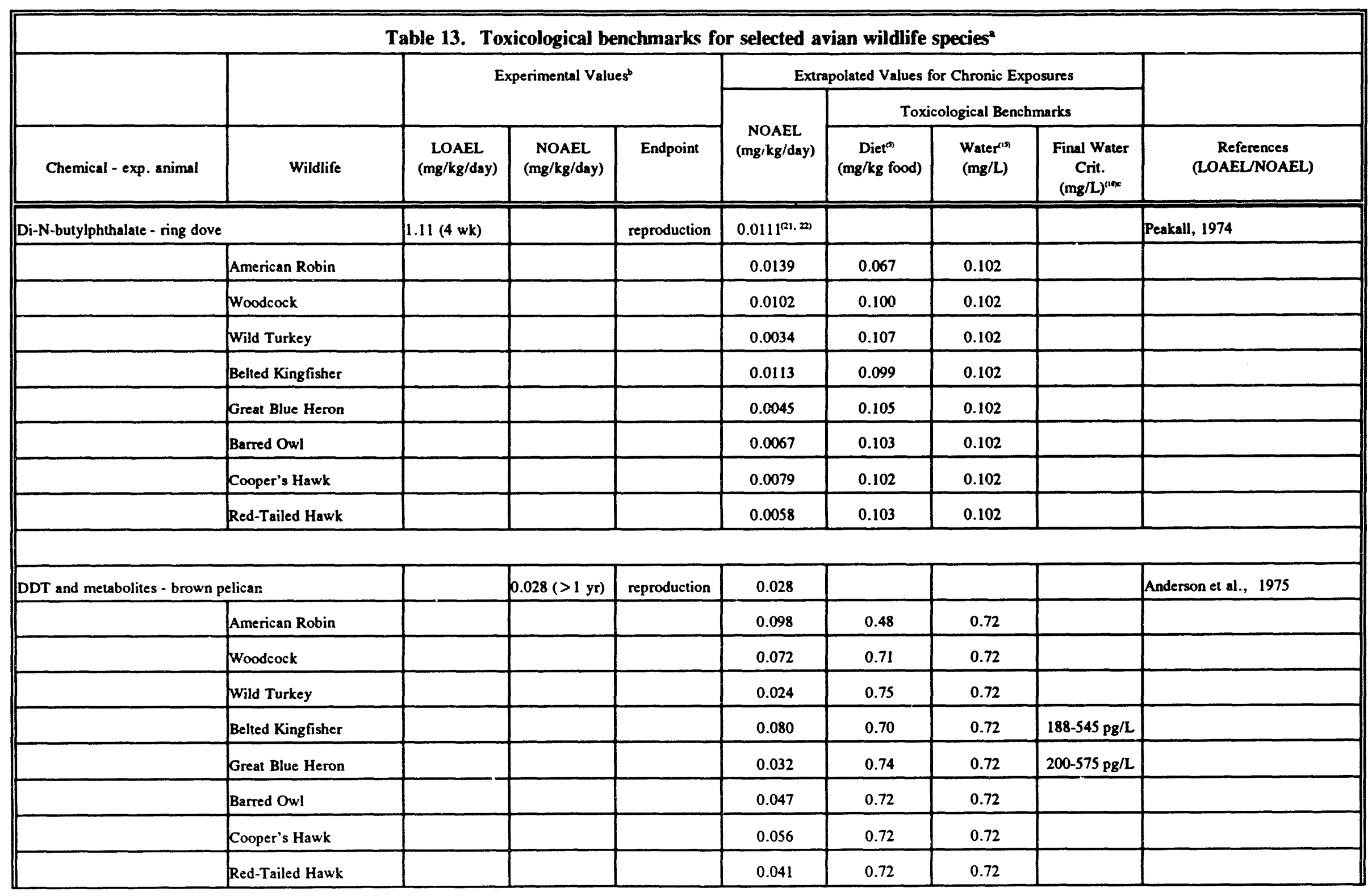




\begin{tabular}{|c|c|c|c|c|c|c|c|c|c|}
\hline \multirow[b]{3}{*}{ Chemical - exp. animal } & \multirow[b]{3}{*}{ Wildlife } & \multirow{2}{*}{\multicolumn{3}{|c|}{ Experimental Values ${ }^{b}$}} & \multicolumn{4}{|c|}{ Extrapolated Values for Chronic Exposures } & \multirow[b]{3}{*}{$\begin{array}{c}\text { References } \\
\text { (LOAEL/NOAEL) }\end{array}$} \\
\hline & & & & & \multirow{2}{*}{$\underset{\text { (mg/kg/day) }}{\text { NOAEL }}$} & \multicolumn{3}{|c|}{ Toxicologisal Benchmarks } & \\
\hline & & $\underset{(\mathrm{mg} / \mathrm{kg} / \text { day })}{\mathrm{LOAEL}}$ & $\underset{\text { (mg/kg/day) }}{\text { NOAEL }}$ & Endpoint & & $\begin{array}{c}\operatorname{Diet}^{\infty} \\
\text { (mg/kg food) }\end{array}$ & $\begin{array}{l}\text { Water(1) } \\
(\mathbf{m g} / \mathbf{L})\end{array}$ & $\begin{array}{c}\text { Final Water } \\
\text { Crit. } \\
(\mathrm{mg} / \mathrm{L})^{\text {)ioc }}\end{array}$ & \\
\hline \multicolumn{2}{|c|}{ Di-2-ethylhexylphthalate - ring dove } & & $1.11(4 \mathrm{wk})$ & reproduction & $0.111^{(2)}$ & & & & Peakall, 1974 \\
\hline & American Robin & & & & 0.139 & 0.67 & 1.02 & & \\
\hline & Woodcock & & & & 0.102 & 1.00 & 1.02 & & \\
\hline & Wild Turkey & & & & 0.034 & 1.07 & 1.02 & & \\
\hline & Belted Kingfisher & & & & 0.113 & 0.99 & 1.02 & $3.3 \times 10^{5}-0.008$ & \\
\hline & Great Blue Heron & & & & 0.045 & 1.05 & 1.02 & $4.5 \times 10^{5}-0.008$ & \\
\hline & Barred Owl & & & & 0.067 & 1.03 & 1.02 & & \\
\hline & Cooper's Hawk & & & & 0.079 & 1.02 & 1.02 & & \\
\hline & Red-Tailed Hawk & & & & 0.058 & 1.03 & 1.02 & & \\
\hline \multicolumn{2}{|l|}{ Mercury, methyl - mallard } & 0.064 (3 gen) & & reproduction & $0.0064^{211}$ & & & & Heinz, 1979 \\
\hline & American Robin & & & & 0.015 & 0.072 & 0.108 & & \\
\hline & Woodcock & & & & 0.011 & 0.106 & 0.108 & & \\
\hline & Wild Turkey & & & & 0.0036 & 0.113 & 0.108 & & \\
\hline & Belted Kingfisher & & & & 0.012 & 0.106 & 0.108 & & \\
\hline & Great Blue Heron & & & & 0.005 & 0.111 & 0.108 & & \\
\hline & Barred Owl & & & & 0.007 & 0.109 & 0.108 & & \\
\hline & Cooper's Hawk & & & & 0.008 & 0.108 & 0.108 & & \\
\hline & Red-Tailed Hawk & & & & 0.006 & 0.110 & 0.108 & & \\
\hline
\end{tabular}




\begin{tabular}{|c|c|c|c|c|c|c|c|c|c|}
\hline \multirow[b]{3}{*}{ Chemical - exp. animal } & \multirow[b]{3}{*}{ Wildlife } & \multicolumn{3}{|c|}{ Experimental Values } & \multicolumn{4}{|c|}{ Extrapolated Values for Chronic Exposures } & \multirow[b]{3}{*}{$\begin{array}{c}\text { References } \\
\text { (LOAEL/NOAEL) }\end{array}$} \\
\hline & & & & & \multirow{2}{*}{$\begin{array}{c}\text { NOAEL } \\
\text { (mg/kg/day) }\end{array}$} & \multicolumn{3}{|c|}{ Toxicological Benchmarks } & \\
\hline & & $\underset{\text { (mg/kg/day) }}{\text { LOAEL }}$ & $\begin{array}{c}\text { NOAEL } \\
\text { (mg/kg/day) }\end{array}$ & Endpoint & & $\begin{array}{c}\text { Diet }{ }^{(9)} \\
\text { (mg/kg food) }\end{array}$ & $\begin{array}{l}\text { Water }{ }^{(19)} \\
(\mathrm{mg} / \mathrm{L})\end{array}$ & $\begin{array}{c}\text { Final Water } \\
\text { Crit. } \\
(\mathrm{mg} / \mathrm{L})^{\text {anc }}\end{array}$ & \\
\hline \multicolumn{2}{|c|}{ Nickel sulphate/nickel acetate - chicken } & & $21.4(4 \mathrm{wk})$ & $\begin{array}{l}\text { wt. gain; } \\
\text { metabolism }\end{array}$ & $2.14^{(22)}$ & & & & Weber and Reid, 1968 \\
\hline & American Robin & & & & 4.11 & 19.81 & 29.88 & & \\
\hline & Woodcock & & & & 3.01 & 29.41 & 29.88 & & \\
\hline & Wild Turkey & & & & 0.99 & 31.35 & 29.88 & & \\
\hline & Belted Kingfisher & & & & 3.31 & 29.23 & 29.89 & $6.5 \times 10^{5}-0.0012$ & \\
\hline & Great Blue Heron & & & & 1.32 & 30.83 & 29.88 & $6.7 \times 10^{5}-0.0013$ & \\
\hline & Barred Owl & & & & 1.97 & 30.13 & 29.88 & & \\
\hline & Cooper's Hawk & & & & 2.31 & 29.84 & 29.88 & & \\
\hline & Red-Tailed Hawk & & & & 1.70 & 30.39 & 29.89 & & \\
\hline \multicolumn{2}{|c|}{ PCB (Aroclor 1254) - ring-necked pheasant } & & $1.57(17 w k)$ & reproduction & 1.57 & & & & Dahigren et al., 1972 \\
\hline & American Robin & & & & 3.82 & 18.4 & 27.7 & & \\
\hline & Woodcock & & & & 2.79 & 27.3 & 27.7 & & \\
\hline & Wild Turkey & & & & 0.92 & 29.1 & 27.7 & & \\
\hline & Belted Kingfisher & & & & 3.08 & 27.1 & 27.7 & $0.012-0.8 \mathrm{ug} / \mathrm{L}$ & \\
\hline & Great Blue Heron & & & & 1.23 & 28.6 & 27.7 & $0.012-0.8 \mathrm{ug} / \mathrm{L}$ & \\
\hline & Barred Owl & & & & 1.83 & 28.0 & 27.7 & & \\
\hline & Cooper's Hawk & & & & 2.15 & 27.7 & 27.7 & & \\
\hline & Red-Tailed Hawk & & . & & 1.57 & 28.2 & 27.7 & & \\
\hline
\end{tabular}


Table 13. Toxicological benchmarks for selected avian wildlife species ${ }^{\mathrm{a}}$

\begin{tabular}{|c|c|c|c|c|c|c|c|c|c|}
\hline \multirow[b]{3}{*}{ Chemical - exp. animal } & \multirow[b]{3}{*}{ Wildlife } & \multirow{2}{*}{\multicolumn{3}{|c|}{ Experimental Values }} & \multicolumn{4}{|c|}{ Extrapolated Values for Chronic Exposures } & \multirow[b]{3}{*}{$\begin{array}{c}\text { References } \\
\text { (LOAEL/NOAEL) }\end{array}$} \\
\hline & & & & & \multirow{2}{*}{$\begin{array}{c}\text { NOAEL } \\
\text { (mg/kg/day) }\end{array}$} & \multicolumn{3}{|c|}{ Toxicological Benchmarks } & \\
\hline & & $\underset{\text { (mg/kg/day) }}{\text { LOAEL }}$ & $\begin{array}{c}\text { NOAEL } \\
(\mathrm{mg} / \mathrm{kg} / \mathrm{day})\end{array}$ & Endpoint & & $\begin{array}{c}\operatorname{Diet}^{()} \\
\text {(mg/kg food) }\end{array}$ & $\begin{array}{l}\text { Water }{ }^{115,} \\
\text { (mg/L) }\end{array}$ & $\begin{array}{l}\text { Final Water } \\
\text { Crit. } \\
(\mathrm{mg} / \mathrm{L})^{\text {(10) }}\end{array}$ & \\
\hline \multicolumn{2}{|l|}{ Sodium selenite - mallard duck } & & $1(70 \mathrm{~d})$ & reproduction & $0.1^{(22)}$ & & & & Heinz et al., 1987 \\
\hline & American Robin & & & & 0.23 & 1.12 & 1.69 & & \\
\hline & Woodcock & & & & 0.17 & 1.67 & 1.69 & & \\
\hline & Wild Turkey & & & & 0.06 & 1.78 & 1.69 & & \\
\hline & Belted Kingfisher & & & & 0.19 & 1.66 & 1.70 & & \\
\hline & Great Blue Heron & & & & 0.08 & 1.75 & 1.69 & & \\
\hline & Barred Owl & & & & 0.11 & 1.71 & 1.69 & & \\
\hline & Cooper's Hawk. & & & & 0.13 & 1.69 & 1.69 & & \\
\hline & Red-Tailed Hawk & & & & 0.10 & 1.72 & 1.69 & & \\
\hline \multicolumn{2}{|c|}{ Selanomethionine - mallard duck } & & $0.4(70 \mathrm{~d})$ & reproduction & $0.04^{(2)}$ & & & & Heinz et al., 1989 \\
\hline & American Robin & & & & 0.09 & 0.45 & 0.68 & & \\
\hline & Woodcock & & & & 0.07 & 0.67 & 0.68 & & \\
\hline & Wild Turkey & & & & 0.02 & 0.71 & 0.68 & & \\
\hline & Belted Kingfisher & & & & 0.08 & 0.66 & 0.68 & & \\
\hline & Great Blue Heron & & & & 0.03 & 0.70 & 0.68 & & \\
\hline & Barred Owl & & & & 0.04 & 0.68 & 0.68 & & \\
\hline & Cooper's Hawk & & & & 0.05 & 0.68 & 0.68 & & \\
\hline & Red-Tailed Hawk & & & & 0.04 & 0.69 & 0.68 & & \\
\hline
\end{tabular}




\begin{tabular}{|c|c|c|c|c|c|c|c|c|c|}
\hline \multirow[b]{3}{*}{ Chemical - exp. animal } & \multirow[b]{3}{*}{ Wildlife } & \multicolumn{3}{|c|}{ Experimental Values ${ }^{b}$} & \multicolumn{4}{|c|}{ Extrapolated Values for Chronic Exposures } & \multirow[b]{3}{*}{$\begin{array}{c}\text { References } \\
\text { (LOAEL/NOAEL) }\end{array}$} \\
\hline & & & & & \multirow{2}{*}{$\begin{array}{c}\text { NOAEL } \\
(\mathrm{mg} / \mathrm{kg} / \mathrm{day})\end{array}$} & \multicolumn{3}{|c|}{ Toxicological Benchmarks } & \\
\hline & & $\begin{array}{c}\text { LOAEL } \\
\text { (mg/kg/day) }\end{array}$ & $\begin{array}{c}\text { NOAEL } \\
\text { (mg/kg/day) }\end{array}$ & Endpoint & & $\begin{array}{c}\operatorname{Diet}^{(5)} \\
\text { (mg/kg food) }\end{array}$ & $\begin{array}{l}\text { Water } \\
(\mathrm{mg} / \mathrm{L})\end{array}$ & $\begin{array}{c}\text { Final Water } \\
\text { Crit. } \\
(\mathrm{mg} / \mathrm{L})^{\operatorname{anc}}\end{array}$ & \\
\hline \multicolumn{2}{|c|}{$2,3,7,8-\mathrm{TCDD}$ - ring-necked pheasant } & & $\begin{array}{l}0.014 \\
\mathrm{ug} / \mathrm{kg} / \mathrm{day}(10 \\
w \mathrm{k})\end{array}$ & reproduction & $0.014 \mathrm{ug} / \mathrm{kg} / \mathrm{d}$ & & & & Nosek et al., 1992 \\
\hline & American Robin & & & & $0.034 \mathrm{ug} / \mathrm{kg} / \mathrm{d}$ & $0.16 \mathrm{ug} / \mathrm{kg}$ & $0.24 \mathrm{ug} / \mathrm{L}$ & & \\
\hline & Woodcock & & & . & $0.025 \mathrm{ug} / \mathrm{kg} / \mathrm{d}$ & $0.24 \mathrm{ug} / \mathrm{kg}$ & $0.24 \mathrm{ug} / \mathrm{L}$ & & \\
\hline & Wild Turkey & & . & & $0.008 \mathrm{ug} / \mathrm{kg} / \mathrm{d}$ & $0.26 \mathrm{ug} / \mathrm{kg}$ & $0.24 \mathrm{ug} / \mathrm{L}$ & & \\
\hline & Belted Kingfisher & & & & $0.027 \mathrm{ug} / \mathrm{kg} / \mathrm{d}$ & $0.24 \mathrm{ug} / \mathrm{kg}$ & $0.24 \mathrm{ug} / \mathrm{L}$ & $0.001-0.3 \mathrm{pg} / \mathrm{L}$ & \\
\hline & Great Blue Heron & & & & $0.011 \mathrm{ug} / \mathrm{kg} / \mathrm{d}$ & $0.25 \mathrm{ug} / \mathrm{kg}$ & $0.24 \mathrm{ug} / \mathrm{L}$ & $0.04-0.3 \mathrm{pg} / \mathrm{L}$ & \\
\hline & Barred Owl & & & & $0.016 \mathrm{ug} / \mathrm{kg} / \mathrm{d}$ & $0.25 \mathrm{ug} / \mathrm{kg}$ & $0.24 \mathrm{ug} / \mathrm{L}$ & & \\
\hline & Cooper's Hawk & & & & $0.019 \mathrm{ug} / \mathrm{kg} / \mathrm{d}$ & $0.25 \mathrm{ug} / \mathrm{kg}$ & $0.24 \mathrm{ug} / \mathrm{L}$ & & \\
\hline & Red-Tailed Hawk & & & & $0.014 \mathrm{ug} / \mathrm{kg} / \mathrm{d}$ & $0.25 \mathrm{ug} / \mathrm{kg}$ & $0.24 \mathrm{ug} / \mathrm{L}$ & & \\
\hline \multicolumn{2}{|l|}{ 2,3,7,8-TCDF - chicken } & $\begin{array}{l}0.1 \text { ug } / \mathrm{kg} / \mathrm{day} \\
(21 \mathrm{~d})\end{array}$ & & $\begin{array}{l}\text { wt. gain; } \\
\text { mortality }\end{array}$ & $\begin{array}{c}0.001^{(21.22)} \\
\mathrm{ug} / \mathrm{kg} / \mathrm{d}\end{array}$ & & & & McKinney et al., 1976 \\
\hline & American Robin & & & & $0.001 \mathrm{ug} / \mathrm{kg} / \mathrm{d}$ & $0.006 \mathrm{ug} / \mathrm{kg}$ & $0.0097 \mathrm{ug} / \mathrm{L}$ & & \\
\hline & Woodcock & & & & $0.001 \mathrm{ug} / \mathrm{kg} / \mathrm{d}$ & $0.009 \mathrm{ug} / \mathrm{kg}$ & $0.0097 \mathrm{ug} / \mathrm{L}$ & & \\
\hline & Wild Turkey & & & & $0.0003 \mathrm{ug} / \mathrm{kg} / \mathrm{d}$ & $0.01 \mathrm{ug} / \mathrm{kg}$ & $0.0097 \mathrm{ug} / \mathrm{L}$ & & \\
\hline & Belted Kingfisher & & & & $0.001 \mathrm{ug} / \mathrm{kg} / \mathrm{d}$ & $0.009 \mathrm{ug} / \mathrm{kg}$ & $0.0097 \mathrm{ug} / \mathrm{L}$ & & \\
\hline & Great Blue Heron & & & & $0.0004 \mathrm{ug} / \mathrm{kg} / \mathrm{d}$ & $0.01 \mathrm{ug} / \mathrm{kg}$ & $0.0097 \mathrm{ug} / \mathrm{L}$ & & \\
\hline & Barred Ow: & & & & $0.0006 \mathrm{ug} / \mathrm{kg} / \mathrm{d}$ & $0.01 \mathrm{ug} / \mathrm{kg}$ & $0.0097 \mathrm{ug} / \mathrm{L}$ & & \\
\hline & Cooper's Hawk & & & & $0.0008 \mathrm{ug} / \mathrm{kg} / \mathrm{d}$ & $0.01 \mathrm{ug} / \mathrm{kg}$ & $0.0097 \mathrm{ug} / \mathrm{L}$ & & \\
\hline & Red-Tailed Hawk & & & & $0.0006 \mathrm{ug} / \mathrm{kg} / \mathrm{d}$ & $0.01 \mathrm{ug} / \mathrm{kg}$ & $0.0097 \mathrm{ug} / \mathrm{L}$ & & \\
\hline
\end{tabular}




\begin{tabular}{|c|c|c|c|c|c|c|c|c|c|}
\hline \multirow[b]{3}{*}{ Chemical - exp. animal } & \multirow[b]{3}{*}{ Wildlife } & \multirow{2}{*}{\multicolumn{3}{|c|}{ Experimental Values }} & \multicolumn{4}{|c|}{ Extrapolated Values for Chronic Exposures } & \multirow[b]{3}{*}{$\begin{array}{c}\text { References } \\
\text { (LOAEL/NOAEL) }\end{array}$} \\
\hline & & & & & \multirow{2}{*}{$\begin{array}{c}\text { NOAEL } \\
\text { (mg/kg/day) }\end{array}$} & \multicolumn{3}{|c|}{ Toxicological Benchmarks } & \\
\hline & & $\underset{\text { (mg/kg/day) }}{\text { LOAEL }}$ & $\underset{\text { (mg/kg/day) }}{\text { NOAEL }}$ & Endpoint & & $\begin{array}{c}\operatorname{Diet}^{(9)} \\
\text { (mg/kg food) }\end{array}$ & $\begin{array}{l}\text { Water } \\
(\mathrm{mg} / \mathrm{L})\end{array}$ & $\begin{array}{c}\text { Final Water } \\
\text { Crit. } \\
(\mathrm{mg} / \mathrm{L})^{a 10 x}\end{array}$ & \\
\hline \multicolumn{2}{|c|}{ Uranium (depleted, metallic) - black duck } & & $86(6 \mathrm{wk})$ & $\begin{array}{c}\text { liver, kidney, } \\
\text { mortality }\end{array}$ & $8.6^{(22)}$ & & & & Haseltine and Sileo, 1983 \\
\hline & American Robin & & & & 21.6 & 104 & 156 & & \\
\hline & Woodcock & & & & 15.8 & 154 & 156 & & \\
\hline & Wild Turkey & & & & 5.2 & 165 & 156 & & \\
\hline & Belted Kingfisher & & & & 17.4 & 153 & 156 & & \\
\hline & Great Blue Heron & & & & 6.9 & 162 & 156 & & \\
\hline & Barred Owl & & & & 10.3 & 158 & 156 & & \\
\hline & Cooper's Hawk & & & & 12.1 & 157 & 156 & & \\
\hline & Red-Tailed Hawk & & & & 8.9 & 160 & 156 & & \\
\hline \multicolumn{2}{|l|}{ |Zinc carbonate - mallard } & $170(60 \mathrm{~d})$ & & $\begin{array}{c}\text { blood chem.; } \\
\text { mortality }\end{array}$ & $1.7^{21.221}$ & & & & Gasaway and Buss, 1972 \\
\hline & American Robin & & & & 4.1 & 19.6 & 29.5 & & \\
\hline & Woodcock & & & & 3.0 & 29.1 & 29.5 & & \\
\hline & Wild Turkey & & & & 1.0 & 31.0 & 29.5 & & \\
\hline & Belted Kingfisher & & & & 3.3 & 28.9 & 29.5 & & \\
\hline & Great Blue Heron & & & & 1.3 & 30.5 & 29.5 & & \\
\hline & Barred Owl & & & & 1.9 & 29.8 & 29.5 & & \\
\hline & Cooper's Hawk & & & & 2.3 & 29.5 & 29.5 & & \\
\hline & Red-Tailed Hawk & & & & 1.7 & 30.0 & 29.5 & & \\
\hline
\end{tabular}

- Numbers in parentheses refer to equations in text.

- Calculated from Equation 16 using FCM values given in Table 8 and $\log$ P and BCF values given in Table 10.

- Dietary concentration in $\mathrm{mg} / \mathrm{kg}$ food; water concentration in $\mathrm{mg} / \mathrm{L}$ 


\section{REFERENCES}

Ambrose, A.M., P.S. Larson, J.F. Borzelleca, and G.R. Hennigar, Jr. 1976. "Long-term toxicologic assessment of nickel in rats and dogs." J. Food Sci. Tech. 13: 181-187.

Anderson, D.W., R.W. Risebrough, L.A. Woods, Jr., L.R. DeWeese, and W.G. Edgecomb. 1975. "Brown pelicans: improved reproduction off the southern California coast." Science 190: 806-808.

Aulerich, R.J. and R.K. Ringer. 1977. "Current status of PCB toxicity, including reproduction in mink." Arch. Environ. Contam. Toxicol. 6:279.

ATSDR (Agency for Toxic Substances and Disease Registry). 1989a. Toxicological profile for selected PCBs (Aroclor-1260, -1254, -1248, -1242, -1232, -1221, and -1016). ATSDR/TP-88/21.

ATSDR (Agency for Toxic Substances and Disease Registry). 1989b Toxicological profile for 2,3,7,8-tetrachlorodibenzo-p-dioxin. ATSDR/TP-88/23.

ATSDR (Agency for Toxic Substances and Disease Registry). 1990a. Toxicological profile for asbestos. ATSDR/TP-90/04.

ATSDR (Agency for Toxic Substances and Disease Registry). 1990b. Toxicological profile for total xylenes. ATSDR/TP-90/26.

ATSDR (Agency for Toxic Substances and Disease Registry). 1990c. Toxicological profile for lead. U.S. Dept. Health Human Serv., Publ. Health Serv., Atlanta, GA.

Azar, A., H.J. Trochimowicz, and M.E. Maxwell. 1973. "Review of lead studies in animals carried out at Haskell Laboratory: two-year feeding study and response to hemorrhage study." In: Environmental Health Aspects of Lead: Proceedings, International Symposium, D. Barth et al., eds. Commission of European Communities. pp. 199-210. (As cited in ATSDR, 1990c).

Baroni, C., G.J. VanEsch, and U. Saffiotti. 1963. "Carcinogenesis tests of two inorganic arsenicals." Arch. Environ. Health. 7: 668-674.

Baxley, M.N., R.D. Hood, G.C. Vedel, W.P. Harrison, and G.M. Szczech. 1981. "Prenatal toxicity of orally administered sodium arsenite in mice." Bull. Environ. Contam. Toxicol. 26: 749-756.

Blakely, B.R., C.S. Sisodia, and T.K. Mukkur. 1980. "The effect of methyl mercury, tetrethyl lead, and sodium arsenite on the humoral immune response in mice." Toxicol. Appl. Pharmacol. 52: 245-254. 
Bleavins, M.R., R.J. Aulerich, and R.K. Ringer. 1980. "Polychlorinated biphenyls (Aroclors 1016 and 1242): Effect on survival and reproduction in mink and ferrets." Arch. Environ. Contam. Toxicol. 9:627-635.

Bosch, H.M., A.B. Rosenfield, R. Huston, et al. 1950. "Methemoglobinemia and Minnesota well supplies." J. Am. Water Works Assoc. 42:161-170.

Boyden, R., V.R. Potter, and C.A. Elvehjem. 1938. "Effect of feeding high levels of copper to albino rats." J. Nutr. 15: 397-402.

Bruckner, J.V., W.F. Mackenzie, S. Muralidhara, R. Luthra, G.M. Kyle, and D. Acosta. 1986. "Oral toxicity of carbon tetrachloride: acute, subacute, and subchronic studies in rats." Fund. Appl. Toxicol. 6:16-34.

Buben, J.A. and E.J. O'Flaherty. 1985. "Delineation of the role of metabolism in the hepatotoxicity of trichloroethylene and perchloroethylene: a dose-effect study." Toxicol. Appl. Pharmacol. 78:105-122.

Businco, L. 1940. "The rickets-producing effect of beryllium carbonate." Rass. Med. Ind. 11:417-442.

Byron, W.R., G.W. Bierbower, J.B. Brower, and W.H. Hansen. 1967. "Pathological changes in rats and dogs from two-year feeding of sodium arsenite or sodium arsenate." Toxicol. Appl. Pharmacol. 10: 132-147.

Calder, W.A. and E.J. Braun. 1983. "Scaling of osmotic regulation in mammals and birds." Am. J. Physiol. 224: Rr601-R606.

Collins, W.T. and C.C. Capen. 1980. "Fine structural lesions and hormonal alterations in thyroid glands of perinatal rats exposed in utero and by milk to polychlorinated biphenyls. Am. J. Pathol. 99: 125-142.

Dahlgren, R.B., R.L. Linder, and C.W. Carlson. 1972. "Polychlorinated biphenyls: their effects on penned pheasants." Environ. Health Perspect. 1: 89-101.

Dow Chemical Company. 1984. Summary of Report on Lifespan Oral Carcinogenicity Study of Vinyl Chloride in Rats. FYI-OTS-1084-0353IN. (Cited in EPA, 1985).

Dunning, J.B. 1984. "Body weights of 686 species of North American birds." West. Bird Banding Assoc. Monogr. No. 1. Eldon Publ. Co. Cave Crk. AZ. 38 pp.

Eisler, R. 1985. Cadmium Hazards to Fish, Wildlife, and Invertebrates: A Synotic Review. Biological Report 85(1.2)24. Fish and Wildlife Service, U.S. Department of the Interior, Washington, D.C. 
Eisler, R. 1986. Chromium Hazards to Fish, Wildlife, and Invertebrates: A Synotic Review. Biological Report 85(1.6). Fish and Wildlife Service, U.S. Department of the Interior, Washington, D.C.

EPA (U. S. Environmental Protection Agency). 1980. "Guidelines and Methodology Used in the Preparation of Health Effects Assessment Chapters of the Consent Decree Water Quality Criteria Documents." Federal Register 45 (231):79347-79356.

EPA (U. S. Environmental Protection Agency). 1985. Reference Values for Risk Assessment. Prepared by Syracuse Research Corporation, Syracuse, NY for Environmental Criteria and Assessment Office, Cincinnati, $\mathrm{OH}$.

EPA (U. S. Environmental Protection Agency). 1985b. Health and Environmental Effects Profile for Chloroethene. Prepared by the Environmental Criteria and Assessment Office, Office of Health and Environmental Assessment, Cincinnati, OH. EPA-CIN-P155.

EPA (U. S. Environmental Protection Agency). 1986a. Toxicology Handbook. Government Institutes, Inc., Rockville, MD

EPA (U. S. Environmental Protection Agency). 1986b. "Guidelines for Carcinogenic Risk Assessment." Federal Register 51:33992.

EPA (U. S. Environmental Protection Agency). 1986c. 90-Day Gavage Study in Albino Rats Using Acetone. Office of Solid Waste, Washington, D.C.

EPA (U. S. Environmental Protection Agency). 1986d. 90-Day Oral Toxicity Study of Copper Cyanide. Office of Solid Waste, Washington, D.C.

EPA (U. S. Environmental Protection Agency). 1986e. Rat Oral Subchronic Study with Ethyl Acetate. Office of Solid Waste, Washington, D.C.

EPA (U. S. Environmental Protection Agency). 1986f. Rat Oral Subchronic Study with Methanol, Office of Solid Waste, Washington, D.C.

EPA (U. S. Environmental Protection Agency). 1987. Recommendations for and Documentation of Biological Values for Use in Risk Assessment. ECAO-CIN-554. Final Draft. Environmental Criteria and Assessment Office, Cincinnati, $\mathrm{OH}$.

EPA (U. S. Environmental Protection Agency). 1988. Methodology for Evaluating Potential Carcinogenicity in Support of Reportable Quantity Adjustments Pursuant to CERCLA Section 102. OHEA-C-073, External Review Draft. Office of Health and Environmental Assessment, Washington, D.C.

EPA (U. S. Environmental Protection Agency). 1989. Water Quality Criteria to Protect Wildlife Resources. EPA/600/3-89/067. Environmental Research Laboratory, Corvallis, OR. 
EPA (U. S. Environmental Protection Agency). 1993. "Water quality guidance for the Great Lakes System and correction; proposed rules." Federal Register 58: 20802-21047.

Feron, V.J., C.F.M. Hendriksen, A.J. Speek, et al. 1981. "Lifespan oral toxicity study of vinyl chloride in rats." Food Cosmetic Toxicol. 13:633-638.

Garthoff, L.H., F.E. Cerra, and E.M. Marks. 1981. "Blood chemistry alteration in rats after single and multiple gavage administration of polychlorinated biphenyls." Toxicol. Appl. Pharmacol. 60: 33-44.

Gasaway, W.C. and 1.O. Buss. 1972. "Zinc toxicity in the mallard." J. Wildl. Mgmt. 36: 1107-1117.

Getz, L.L. 1968. "A comparison of the water balance of the forest deer mouse and the whitefooted mouse." J. Mammal. 49:520-522.

Harrison, J.W., E.W. Packman, and D.D. Abbott. 1958. "Acute oral toxicity and chemical and physical properties of arsenic trioxides." Arch. Ind. Health. 17: 118-123.

Haseltine, S.D. and L. Sileo. 1983. "Response of American black ducks to dietary uranium: a proposed substitute for lead shot." J. Wildl. Mgmt. 47: 1124-1129.

Haseltine, S.D. et al. 1985. Effects of chromium on reproduction and growth in black ducks. Cited in Eisler, 1986.

Heinz, G.H. 1979. "Methyl mercury: reproductive and behavioral effects on three generations of mallard ducks." J. Wildl. Mgmt. 43: 394-401.

Heinz, G.H. and S.D. Haseltine. 1983. "Altered avoidance behavior of young black duck fed cadmium." Environ. Toxicol. Chem. 2:419-421. Cited in Eisler, 1985.

Heinz, G.H., D.J. Hoffman, A.J. Krynitsky, and D.M.G. Weller. 1987. "Reproduction in mallards fed selenium." Environ. Toxicol. Chem. 6: 423-433.

Heinz, G.H., D.J. Hoffman, and L.G. Gold. 1989. "Impaired reproduction of mallards fed an organic form of selenium." J. Wildl. Mgmt. 53: 418-428.

Heppel, L.A., P.A. Neal, T.L. Perrin, et al. 1946. "The toxicology of 1,2-dichloroethane (ethylene dichloride)." J. Ind. Hyg. Tox. 28:113-120.

Heywood, R., R.J. Sortwell, P.R.B. Noel, et al. 1979. "Safety evaluation of toothpaste containing chloroform. III. Long-term study in beagle dogs." J. Environ. Pathol. Toxicol. 2:835-851.

Hilderbrand, D.C., R. Der, W.T. Griffin, et al. 1973. "Effect of lead acetate on reproduction." Am J. Obstet. Gynecol. 115:1058-1065. 
Hofmann, H.T., H. Birnsteil, and P. Jobst. 1971. "Zur Inhalation Toxicitat von 1,1- und 1,2Dichloroanth." Arch Toxikol. 27:248-265.

Howard, J.W. and R.F. Hanzal. 1955. "Chronic toxicity for rats of food treated with hydrogen cyanide." Agric. Food. Chem. 3:325-329.

Hudson, R. H., R. K. Tucker, and M. A. Haegele. 1984. Handbook of toxicity of pesticides to wildlife. U.S. Fish and Wildl. Serv. Resour. Publ. 153. 90 pp.

Huff, J.E., J.K. Kaseman, D.M. DeMarini, et al. 1989. "Multiple site carcinogenicity of benzene in Fischer 344 rats and B6C3F, mice." Environ. Health Perspect. 82: 125-163.

Infurna, R. and B. Weiss. 1986. "Neonatal behavioral toxicity in rats following prenatal exposure to methanol." Teratology 33:259-265.

Kinnamon, K.E. 1963. "Some independent and combined effects of copper, molybdenum, and zinc on the placental transfer of zinc-65 in the rat." J. Nutr. 81: 312-320.

Labelle, C.W. and H. Brieger. 1955. "Vapour toxicity of a composite solvent and its principal components." Arch. Ind. Health. 12:623-627.

Lamb, J.C., IV, R.E. Chapin, J. Teague, A.D. Lawton, and J.R. Reel. 1987. "Reproductive effects of four phthalic acid esters in the mouse." Toxicol. Appl. Pharmacol. 88: 255-269.

Linder, R.E., T.B. Gaines, and R.D. Kimbrough. 1974. "The effect of PCB on rat reproduction." Food Cosmet. Toxicol. 12: 63.

Linzey, A.V. 1987. "Effects of chronic polychlorinated biphenyls exposure on reproductive success of white-footed mice (Peromyscus leucopus)." Arch. Environ. Contamin. Toxicol. 16:455-460.

Klein, J.A. 1989. "A checklist of the reptiles and amphibians on the Department of Energy Oak Ridge Reservation, Anderson and Roane Counties, Tennessee." J. Tenn. Acad. Sci. 64: 228-230.

Knoflach, P., B. Albini, and M.M. Weiser. 1986. "Autoimmune disease induced by oral administration of mercuric chloride in brown-Norway rats." Toxicol. Pathol. 14:188-193.

Kurokawa, Y., M. Matsushima, I. Imazawa, et al. 1985. "Promoting effects of metal compounds on rat renal tumorigenesis." J. Am. Coll. Toxicol. 4:321-330.

Mabey, W.R., J.H. Smith, and R.T. Podol. 1982. Aquatic fate process data for organic priority pollutants. Washington, D.C. EPA. Office of Water Reg. and Stand. EPA 440/481-014. 
Mackenzie, K.M. and D.M. Angevine. 1981. "Infertility in mice exposed in utero to benzo[a]pyrene." Biol. Reprod. 24: 183-191.

Mackenzie, R.D., R.U. Byerrum, C.F. Decker, et al. 1958. "Chronic toxicity studies, II. Hexavalent and trivalent chromium administered in drinking water to rats." Am. Med. Assoc. Arch. Ind. Health. 18:232-234.

Massie, H.R. and V.R. Aeillo. 1984. "Excessive copper: influence on longevity and cadmium accumulation in mice." Mech. Age. Dev. 26: 195-203.

Maynard, E.A. and H.C. Hodge. 1949. "Studies of the toxicity of various uranium compounds when feed to experimental animals." In: The Pharmacology and Toxicology of Uranium Compounds. C. Voegtlin and H.C. Hodge, eds. McGraw-Hill, New York, pp. 309-376.

McKinney, J.D., K. Chae, B.N. Gupta, J.A. Moore, and J.A. Goldstein. 1976. "Toxicological assessment of hexachlorobiphenyl and 2,3,7,8-tetrachlorodibenzofuran in chicks. 1 . Relationship of chemical parameters." Toxicol. Appl. Pharmacol. 36: 65-80.

Mehring, A.L. Jr., J.H. Brumbaugh, A.J. Sutherland, and H.W. Titus. 1960. "The tolerance of growing chickens for dietary copper." Poult. Sci. 39: 713-719.

Merson, M.H. and R.L. Kirkpatrick. 1976. "Reproductive performance of captive white-footed mice fed a polychlorinated biphenyl." Bull. Environ. Contam. Toxicol. 16: 392-398.

Meyers, S.M. and S.M. Schiller. 1986. "TERRE-TOX: a data base for the effects of anthropogenic substances on terrestrial animals." J. Chem. Info. Comp. Sci. 26: 33-36.

Microbiological Associates. 1986. Subchronic Toxicity of Methyl lsobutyl Ketone in SpragueDawley rats. Study No. 5221.04. Preliminary report to Research Triangle Institute, Research Triangle Park, NC.

Murray, F.J., F.A. Smith, K.D. Nitschke, C.G. Humiston, R.J. Kociba, and B.A. Schwetz. 1979. "Three-generation reproduction study of rats given 2,3,7,8-tetrachlorodibenzo-pdioxin (TCDD) in the diet." Toxicol. Appl. Pharmacol. 50: 241-252.

Nagy, K.A. 1987. "Field metabolic rate and food requirement scaling in mammals and birds." Ecol. Monogr. 57: 111-128.

NAS. 1977. Arsenic. Nat'l. Acad. Aci., Washington, D.C. $332 \mathrm{pp.}$

NCA (National Coffe Association). 1982. 24-Month Chronic Toxicity and Oncogenicity Study of Methylene Chloride in Rats. Final Report. Hazelton Laboratories, Inc., Vienna VA.

NCI (National Cancer Institute). 1977a. Bioassay of Tetrachloroethylene for Possible Carcinogenicity. NCl Carcinogenesis Tech. Rept. Series Co. NCI-CGTR-13. 
NCI (National Cancer Institute). 1977b. Bioassay of Trichloroethylene for Possible Carcinogenicity. NCI Carcinogenesis Tech. Rept. Series Co. NCI-CH-TR-3.

NCI (National Cancer Institute). 1978. Bioassay of Aroclor 1254 for possible carcinogenicity. NCI Carcinogenesis Technical Rep. Series No. 38, NCI-CG-TR-38, DHEW Pub. No. (NIH) 78-838.

Neiger, R.D. and G.D. Osweiler. 1989. "Effect of subacute low level dietary sodium arsenite on dogs." Fund. Appl. Toxicol. 13: 439-451.

Nosek, J.A., S.R. Craven, J.R. Sullivan, S.S. Hurley, and R.E. Peterson. 1992. "Toxicity and reproductive effects of 2,3,7,8-tetrachlorodibenzo-p-dioxin in ring-necked pheasants." J. Toxicol. Environ. Health. 35: 187-198.

NRCC. 1978. "Effects of arsenic in the Canadian environment." Natl. Res. Coun. Canada. Publ. No. NRCC 15391. 349 pp.

NTP (National Toxicology Program). 1985. Trichloroethylene: Reproduction and Fertility Assessment in CD-1 Mice When Administered in the Feed. U.S. Department of Health and Human Services, National Institutes of Health, Bethesda, MD. NTP-86-068.

NTP (National Toxicology Program). 1986. Trichloroethylene: Reproduction and Fertility Assessment in F344 Rats When Administered in the Feed. U.S. Department of Health and Human Services, National Institutes of Health, Bethesda, MD. NTP-86-085.

NTP (National Toxicology Program). 1989. Toxicology and Carcinogenesis Studies of Toluene in F344 Rats and B6C3F1 Mice. Technical Report. Series No. 371.

Peakall, D.B. 1974. "Effects of di-N-buylphthalate and di-2-ethylhexylphthalate on the eggs of ring doves." Bull. Environ. Contam. Toxicol. 12: 698-702.

Perry, H.M., E.F. Perry, M. N. Erlanger, and S. J. Kopp. 1983. "Cardiovascular effects of chronic barium ingestion." In: Proc. 17th Ann. Conf. Trace Substances in Environ. Health, vol. 17. U. of Missouri Press, Columbia, MO.

Pershagen, G. and M. Vahter. 1979. Arsenic-a toxicological and epidemiological appraisal. Naturvardsverket Rapp. SNV PM 1128, Liber Tryck, Stockholm. 265 pp.

Philbrick, D.J., J.B. Hopkins, D.C. Hill, et al. 1979. "Effects of prolonged cyanide and thiocyanate feeding in rats." J. Toxicol. Health. 5:579-592.

Poiger, H., N. Pluess, and C. Schlatter. 1989. "Subchronic toxicity of some chlorinated dibenzofurans to rats." Chemosphere. 18: 265-275.

Pullar, E.M. 1940. "The toxicity of various copper compounds and mixtures for domesticated birds." Part 2. Aust. Vet. J. 16: 203-213. 
Quast, J.F., C.G. Humiston, C.E. Wade, et al. 1983. "A chronic toxicity and oncogenicity study in rats and subchronic toxicity in dogs on ingested vinylidene chloride." Fund. Appl. Toxicol. 3:55-62.

Revis, N., G. Holdsworth, G. Bingham, A. King, and J. Elmore. 1989. An assessment of health risk associated with mercury in soil and sediment from East Fork Poplar Creek, Oak Ridge, Tennessee. Oak Ridge Research Institute, Final Report, 58 pp.

Ringer, R.K., R.J. Aulerich and M.R. Bleavins. 1981. "Biological effects of PCBs and PBBs on mink and ferrets; a review." In: Halogenated Hydrocarbons: Health and Ecological Effects. M.A.Q. Khan, ed. Permagon Press, Elmsford, NY, pp. 329-343. (Cited in ATSDR, 1989).

Robertson, 1.D., W.E. Harms, and P.J. Ketterer. 1984. "Accidental arsenical toxicity to cattle." Aust. Vet. J. 61: 366-367.

Sanders, O.T. and R.L. Kirkpatrick. 1975. "Effects of a polychlorinated biphenyl on sleeping times, plasma corticosteroids, and testicular activity of white-footed mice." Environ. Physiol. Biochem. 5: 308-313.

Schroeder, H.A. and J.J. Balassa. 1967. "Arsenic, germanium, tin, and vanadium in mice: effects on growth, survival and tissue levels." J. Nutr. 92: 245-252.

Schroeder, H.A., D.D. Balassa, and I.H. Tipton. 1966. Essential trace metals in man: manganese, a study in homeostasis." J. Chron. Dis. 19:545-571.

Schroeder, H.A., M. Kanisawa, D.V. Frost, and M. Mitchener. 1968. "Germanium, tin, and arsenic in rats: effects on growth, survival and tissue levels." J. Nutr. 96: 37-45.

Schroeder, H.A., M. Mitchener, J.J. Balassa, M. Kanisawa, and A.P. Nason. 1968. "Zirconium, niobium, antimony, and fluorine in mice: effects on growth, survival and tissue levels." J. Nutr. 95: 95-101.

Schroeder, H.A and M. Mitchener. 1971. "Toxic effects of trace elements on the reproduction of mice and rats." Arch. Environ. Health. 23: 102-106.

Schroeder, H.A and M. Mitchener. 1975. "Life-term studies in rats: effects of aluminum, barium, beryllium, and tungsten." J. Nutr. 105:421-427.

Skoryna, S.C. 1981. "Effects of oral supplementation with stable strontium." Can. Med. Assoc. J. 125:703-712.

Spencer, H.C., V.K. Rowe, E. M. Adams, et al. 1951. "Vapor toxicity of ethylene dichloride determined by experiments on laboratory animals." Ind. Hyg. Occup. Med. 4:482-493. 
Stickel, L.F., W.H. Stickel, R.A. Dyrland, and D.L. Hughes. 1983. "Oxychlordane, HCS-3260, and nonachlor in birds: lethal residues and loss rates." J. Toxicol and Environ. Health. 12: 611-622.

Suter, G.W., II. 1992. Ecological risk assessment. Lewis Publ. Co., Boca Raton, Fl. 538 pp.

Torkelson, R.R., F. Oyen, D.D. McCollister, and V.K. Rowe. 1958. "Toxicity of 1,1,1Trichloroethane as determined on laboratory animals and human subjects." Am. Ind. Hyg. Assoc. J. 19:353-362.

USAF (U.S. Air Force Systems Command). 1989. The Installation Restoration Program Toxicology Guide. Harry G Armstrong Aerospace Medical Research Laboratory, Wright-Patterson Air Force Base, OH.

Verschueren, K. 1983. Handbook of Environmental Data on Organic Chemicals. Van Nostrand Reinhold Co., NY.

Verschueren, H.G., R. Kroes, E.M. Den Tonkelaar, J.M. Berkvens, P.W. Helleman, A.G. Rauws, P.L. Schuller, and G.J. Van Esch. 1976. "Toxicity of methyl mercury chloride in rats. II. Reproduction study." Toxicol. 6: 97-106.

Villeneuve, D.C., D.L. Grant, K. Khera, D.J. Klegg, H. Baer, and W.E.J. Phillips. 1971. "The fetotoxicity of a polychlorinated biphenyl mixture (Aroclor 1254) in the rabbit and in the rat." Environ. Physiol. 1: 67-71.

Weber, C.W., and B.L: Reid. 1968. "Nickel toxicity to growing chicks." J. Nutr. 95: 612-616.

Whitaker, J.O. 1980. The Audubon Society Field Guide to North American Mammals. Alfred A. Knopf, New York, 745 pp.

WHO (World Health Organization). 1984. Chlordane. Environmental Health Criteria 34. $82 \mathrm{pp}$.

Wobeser, G., N.O. Nielson, and B. Schiefer. 1976. "Mercury and mink II. Experimental methyl mercury intoxication." Can. J. Comp. Med. 34-45.

Woolson, E.A. (Ed.). 1975. "Arsenical pesticides." Am. Chem. Soc. Symp. Ser. 7. 176 pp.

Wren, C.D. 1991. "Cause-effect linkages between chemicals and populations of mink (Nustela vison) and otter (Lutra canadensis) in the Great Lakes Basin." J. Toxicol. Environ. Health. 33:549-585. 
APPENDIX A

Selected Toxicity Data for Avian and Mammalian Wildlife 


\begin{tabular}{|c|c|c|c|c|c|c|}
\hline \multicolumn{7}{|c|}{ Selected toxicity data for avian and mammalian wildlife ${ }^{\mathrm{a}}$} \\
\hline \multirow[b]{2}{*}{ Chemical } & \multirow[b]{2}{*}{ Species } & \multicolumn{2}{|c|}{ LOAEL } & \multirow{2}{*}{$\frac{\text { NOAEL }}{\text { Dose or Conc. }^{b}}$} & \multirow{2}{*}{$\begin{array}{c}\text { Acute or } \\
\text { Lethal } \\
\text { Dose/Conc. }\end{array}$} & \multirow{2}{*}{$\begin{array}{l}L D_{s 0} \text { or } \\
L C_{s 0}\end{array}$} \\
\hline & & Dose or Conc. ${ }^{b}$ & Effect & & & \\
\hline Acrolein & mallard duck & & & & 3.3 & 9.11 \\
\hline 2-Aminobutane base & rat & & & & & 350 \\
\hline 2-Aminobutane acetate & rat & & & & & 480 \\
\hline $\begin{array}{l}\text { 2-Aminobutane } \\
\text { hydrochloride }\end{array}$ & rat & & & & & 430 \\
\hline 4-Aminopyridine & $\begin{array}{l}\text { house sparrow } \\
\text { herring gull } \\
\text { pigeon }\end{array}$ & & & & $\begin{array}{c}1.4 \\
4.5 \\
4 \\
\end{array}$ & \\
\hline Antimony & bobwhite quail & & & 60000 (6 wk) & & \\
\hline $\begin{array}{l}\text { Antimony potassium } \\
\text { tartrate }\end{array}$ & albino rat & & & & 300 & 494 \\
\hline Aroclor 1016 & ferret & & & $20 \mathrm{ppm}(9 \mathrm{mo})$ & & \\
\hline Aroclor 1016 & mink & $20 \mathrm{ppm}(9 \mathrm{mo})$ & reproduction & & $20 \mathrm{ppm}$ & \\
\hline Aroclor 1221 & bobwhite quail & & $30 \%$ mortality & & $6000 \mathrm{ppm}(5 \mathrm{~d})$ & \\
\hline Aroclor 1221 & Japanese quail & & & & & $>6000 \mathrm{ppm}(5 \mathrm{~d})$ \\
\hline Aroclor 1221 & $\begin{array}{l}\text { ring-necked } \\
\text { pheasant }\end{array}$ & & & & $\begin{array}{c}>4000 \mathrm{ppm} \\
(5 \mathrm{~d})\end{array}$ & \\
\hline Aroclor 1232 & bobwhite quail & & & & & $3002 \mathrm{ppm}(5 \mathrm{~d})$ \\
\hline Aroclor 1232 & Japanese quail & & & & & $>5000 \mathrm{ppm}(5 \mathrm{~d})$ \\
\hline Aroclor 1232 & $\begin{array}{l}\text { ring-necked } \\
\text { pheasant }\end{array}$ & & & & & 3146 ppm (5 d) \\
\hline
\end{tabular}




\begin{tabular}{|c|c|c|c|c|c|c|}
\hline \multicolumn{7}{|c|}{ Selected toxicity data for avian and mammalian wildlife $\mathrm{e}^{\mathrm{a}}$} \\
\hline \multirow[b]{2}{*}{ Chemical } & \multirow[b]{2}{*}{ Species } & \multicolumn{2}{|c|}{ LOAEL } & \multirow{2}{*}{$\frac{\text { NOAEL }}{\text { Dose or Conc. }^{b}}$} & \multirow{2}{*}{$\begin{array}{l}\text { Acute or } \\
\text { Lethal } \\
\text { Dose/Conc. }\end{array}$} & \multirow{2}{*}{$\begin{array}{c}\mathrm{LD}_{50} \text { or } \\
\mathrm{LC}_{50}\end{array}$} \\
\hline & & Dose or Conc. & Effect & & & \\
\hline Aroclor 1242 & ferret & $20 \mathrm{ppm}(9 \mathrm{mo})$ & reproduction & & $20 \mathrm{ppm}$ & \\
\hline Aroclor 1242 & mink & 5 ppm (9 mo) & reproduction & & $\begin{array}{r}10 \mathrm{ppm} \\
(9 \mathrm{mo})\end{array}$ & $315-833$ \\
\hline Aroclor 1242 & Japanese quail & $\begin{array}{l}321.5 \mathrm{ppm} \\
(21 \mathrm{~d}) \\
\end{array}$ & reproduction & & & \\
\hline Aroclor 1242 & \begin{tabular}{|l} 
Japanese quail \\
\end{tabular} & $10 \mathrm{ppm}(45 \mathrm{~d})$ & reprod. & & & \\
\hline Aroclor 1248 & screech owl & & & $3 \mathrm{ppm}(18 \mathrm{mo})$ & & \\
\hline Aroclor 1248 & chicken & $10 \mathrm{ppm}(8 \mathrm{wk})$ & reprod. & $1 \mathrm{ppm}(8 \mathrm{wk})$ & & \\
\hline Aroclor 1254 & raccoon & $50 \mathrm{mg} / \mathrm{kg}(8 \mathrm{~d})$ & physiology & & & \\
\hline Aroclor 1254 & cottontail rabbit & $10 \mathrm{ppm}(12 \mathrm{wk})$ & wt. loss & & & \\
\hline Aroclor 1254 & $\begin{array}{l}\text { white-footed } \\
\text { mouse }\end{array}$ & $10 \mathrm{ppm} \sqcup$ & $\begin{array}{l}\text { reprod.; decr. } \\
\text { rurv. of pups }\end{array}$ & & & \\
\hline Aroclor 1254 & quail & 50 ppm (14 wk) & reprod. & & & \\
\hline Aroclor 1254 & \begin{tabular}{|l} 
Japanese quail \\
\end{tabular} & $78.1 \mathrm{ppm}(21 \mathrm{~d})$ & reproduction & & & \\
\hline Aroclor 1254 & Japanese quail & & & $20 \mathrm{ppm}(8 \mathrm{wk})$ & & \\
\hline Aroclor 1254 & Japanese quail & $5 \mathrm{ppm}(12 \mathrm{wk})$ & physiol. & & & \\
\hline Aroclor 1254 & mourning dove & $40 \mathrm{ppm}(42 \mathrm{~d})$ & metabolism & & & \\
\hline Aroclor 1254 & \begin{tabular}{|l} 
ring dove \\
\end{tabular} & $10 \mathrm{ppm}$ & reprod. & & & \\
\hline Aroclor 1254 & pheasant & $\begin{array}{l}12.5 \mathrm{mg} \mathrm{(1x/wk}, \\
17 \mathrm{wk})\end{array}$ & & & & \\
\hline
\end{tabular}




\begin{tabular}{|c|c|c|c|c|c|c|}
\hline \multirow[b]{3}{*}{ Chemical } & \multicolumn{4}{|c|}{ Selected toxicity data for avian and mammalian wildlife $\mathrm{e}^{\mathrm{a}}$} & \multirow{3}{*}{$\begin{array}{l}\text { Acute or } \\
\text { Lethal } \\
\text { Dose/Conc. }\end{array}$} & \multirow{3}{*}{$\begin{array}{l}L^{L} D_{50} \text { or } \\
L C_{50}\end{array}$} \\
\hline & & \multicolumn{2}{|c|}{ LOAEL } & \multirow{2}{*}{$\frac{\text { NOAEL }}{\text { Dose or Conc. }^{b}}$} & & \\
\hline & Species & Dose or Conc. ${ }^{b}$ & Effect & & & \\
\hline Aroclor 1260 & bobwhite quail & 5 ppm (4 mo) & thyroid wt. & & & \\
\hline Aroclor 1260 & Japanese quail & $62.5 \mathrm{ppm}(21 \mathrm{~d})$ & reproduction & & & \\
\hline Arsanilic acid & rat & & & & & $216 \mathrm{mg} / \mathrm{kg}$ \\
\hline Cadmium & deer mouse & $1 \mathrm{mg} / \mathrm{L}$ & infertility & & & \\
\hline Cadmium & wood duck & $100 \mathrm{ppm}(3 \mathrm{mo})$ & pathology & $10 \mathrm{ppm}(3 \mathrm{mo})$ & & \\
\hline Cadmium & black duck & 4 ppm (4 mo) & $\begin{array}{l}\text { offspring } \\
\text { behav. }\end{array}$ & & & \\
\hline Cadmium chloride & mallard duck & $\begin{array}{l}20 \mathrm{ppm} \\
(30-90 \mathrm{~d}) \\
\end{array}$ & pathol. & & & \\
\hline Cadmium succinate & bobwhite quail & & & & & $1728 \mathrm{ppm}(5 \mathrm{~d})$ \\
\hline Cadmium succinate & Japanese quail & & & & & $2693 \mathrm{ppm}(5 \mathrm{~d})$ \\
\hline Cadmium succinate & $\begin{array}{l}\text { ring-necked } \\
\text { pheasant } \\
\end{array}$ & & & & & $1411 \mathrm{ppm}(5 \mathrm{~d})$ \\
\hline Cadmium succinate & mallard duck & & & & & $>5000 \mathrm{ppm}(5 \mathrm{~d})$ \\
\hline Chlordane & bobwhite quail & & & & & $331 \mathrm{ppm}$ (5 day) \\
\hline Chlordane & Japanese quail & & & & & $350 \mathrm{ppm}(5 \mathrm{~d})$ \\
\hline Chlordane & Japanese quail & $25 \mathrm{ppm}(8 \mathrm{~d})$ & reproduction & & & \\
\hline Chlordane & $\begin{array}{l}\text { ring-necked } \\
\text { pheasant }\end{array}$ & & & & & $430 \mathrm{ppm}(5 \mathrm{~d})$ \\
\hline Chlordane & mallard duck & & & & & 858 ppm (5 d) \\
\hline
\end{tabular}




\begin{tabular}{|c|c|c|c|c|c|c|}
\hline \multirow[b]{3}{*}{ Chemical } & \multicolumn{4}{|c|}{ Selected toxicity data for avian and mammalian wildlife } & \multirow{3}{*}{$\begin{array}{c}\text { Acute or } \\
\text { Lethal } \\
\text { Dose/Conc. }\end{array}$} & \multirow{3}{*}{$\begin{array}{c}\mathrm{LD}_{s 0} \text { or } \\
\mathbf{L C _ { s 0 }}\end{array}$} \\
\hline & \multirow[b]{2}{*}{ Species } & \multicolumn{2}{|c|}{ LOAEL } & \multirow{2}{*}{$\frac{\text { NOAEL }}{\text { Dose or Conc. }}$} & & \\
\hline & & Dose or Conc. ${ }^{b}$ & Effect & & & \\
\hline Chlormerodrin (as $\mathrm{Hg}$ ) & rat & & & & & 82 \\
\hline 3-Chloro-p-toluidine $\mathrm{HCl}$ & raven & & & & & $\begin{array}{c}15.4 \\
5.6\end{array}$ \\
\hline$"$ & golden eagle & & & & $100 \mathrm{mg} / \mathrm{kg}$ & $10 \mathrm{mg} / \mathrm{kg}$ \\
\hline 3-Chloro-1,2-propanediol & rat & & reproduction & & 10000 & \\
\hline Chromium (trivalent) & $\begin{array}{l}\text { black duck } \\
\text { (young) }\end{array}$ & $10 \mathrm{ppm}$ & survival & & & \\
\hline $\begin{array}{l}\text { Chromium - potassium } \\
\text { dichromate }\end{array}$ & Japanese quail & & $5-d \mathrm{LC}_{50}$ & & & $4400 \mathrm{ppm}$ \\
\hline 2,4,D & deer mouse & & & $3 \mathrm{lb} / \mathrm{acre}$ & & \\
\hline p,p'-DDD & pheasant & & & & & 552 \\
\hline DDD & cowbird & $1500 \mathrm{ppm}(17 \mathrm{~d})$ & lethal & & & \\
\hline DDE & cowbird & $1500 \mathrm{ppm}(27 \mathrm{~d})$ & lethal & & & \\
\hline DDE & Japanese quail & 25 ppm (14 wk) & $\begin{array}{l}\text { reproduction; } \\
\text { liver }\end{array}$ & $5 \mathrm{ppm}(12 \mathrm{wk})$ & & \\
\hline DDE & rat-tailed bat & & & $107 \mathrm{ppm}(40 \mathrm{~d})$ & & \\
\hline p,p'-DDE & mallard duck & $\begin{array}{l}5 \mathrm{ppm} \text { (several } \\
\mathrm{mo} \text { ) }\end{array}$ & thin egg shells & $1 \mathrm{ppm}$ & & \\
\hline p.p'-DDE & black duck & $\begin{array}{l}10 \mathrm{ppm}(6 \\
\mathrm{mo} / \mathrm{yr})\end{array}$ & thin egg shells & & & \\
\hline p,p'-DDE & pigeon & $18 \mathrm{mg} / \mathrm{kg}(8 \mathrm{wk})$ & & & 36 (8 wk) & \\
\hline
\end{tabular}




\begin{tabular}{|c|c|c|c|c|c|c|}
\hline \multicolumn{7}{|c|}{ Selected toxicity data for avian and mammalian wildlife $\mathrm{a}^{\mathrm{a}}$} \\
\hline \multirow[b]{2}{*}{ Chemical } & \multirow[b]{2}{*}{ Species } & \multicolumn{2}{|c|}{ LOAEL } & \multirow{2}{*}{$\frac{\text { NOAEL }}{\text { Dose or Conc. }^{b}}$} & \multirow{2}{*}{$\begin{array}{l}\text { Acute or } \\
\text { Lethal } \\
\text { Dose/Conc. }\end{array}$} & \multirow{2}{*}{$\begin{array}{c}\mathrm{LD}_{50} \text { or } \\
\mathrm{LC}_{50}\end{array}$} \\
\hline & & Dose or Conc. ${ }^{b}$ & Effect & & & \\
\hline DDT & Japanese quail & $25 \mathrm{ppm}(14 \mathrm{wk})$ & reproduction & & & \\
\hline DDT & Japanese quail & $50 \mathrm{ppm}(10 \mathrm{wk})$ & reproduction & $5 \mathrm{ppm}(10 \mathrm{wk})$ & & \\
\hline DDT & bobwhite quail & $500 \mathrm{ppm}(4 \mathrm{mo})$ & thyroid & $50 \mathrm{ppm}(4 \mathrm{mo})$ & & \\
\hline DDT & mallard duck & $330 \mathrm{ppm}(5 \mathrm{~d})$ & growth & & & \\
\hline DDT & mallard duck & $50 \mathrm{ppm}(6 \mathrm{mo})$ & & & & \\
\hline DDT & mallard duck & & & & & $1869 \mathrm{ppm}(5 \mathrm{~d})$ \\
\hline DDT & house sparrow & & & & $1500 \mathrm{ppm}(3 \mathrm{~d})$ & \\
\hline DDT & $\begin{array}{l}\text { white-throated } \\
\text { sparrow }\end{array}$ & $5 \mathrm{ppm}(11 \mathrm{wk})$ & $\begin{array}{l}\text { behav.; } \\
\text { physiol. }\end{array}$ & & & \\
\hline DDT & earthworm & $5 \mathrm{lb} / \mathrm{acre}$ & decr. pop. & & & \\
\hline Di-butyl phthalate & mallard duck & & $\begin{array}{l}5-d \text { lethal } \\
\text { conc. }\end{array}$ & & $>5000 \mathrm{ppm}$ & \\
\hline Di-butyl phthalate & ring dove & $10 \mathrm{ppm}$ & thin egg shells & & & \\
\hline $\begin{array}{l}\text { 2,4-Dichlorophenyl-p- } \\
\text { nitrophenyl ether }\end{array}$ & rat & 100 ppm (97 wk) & reproduction & 10 ppm (3 gen.) & & 2600 \\
\hline$"$ & $\operatorname{dog}$ & & & $2000 \mathrm{ppm}(2 \mathrm{yr})$ & & \\
\hline Di(2-ethylhexyl)phthalate & ferret & $\begin{array}{l}10,000 \mathrm{ppm} \\
(14 \mathrm{mo})\end{array}$ & physiol. & & & \\
\hline Di(2-ethylhexyl)phthalate & ring dove & & & $10 \mathrm{ppm}$ & & \\
\hline Ferrous sulfate & rat & & & & & $1187 \mathrm{mg} / \mathrm{kg}$ \\
\hline
\end{tabular}




\begin{tabular}{|c|c|c|c|c|c|c|}
\hline \multicolumn{7}{|c|}{ Selected toxicity data for avian and mammalian wildlife ${ }^{\mathrm{a}}$} \\
\hline \multirow[b]{2}{*}{ Chemical } & \multirow[b]{2}{*}{ Species } & \multicolumn{2}{|c|}{ LOAEL } & \multirow{2}{*}{$\begin{array}{c}\text { NOAEL } \\
\text { Dose or Conc. } \\
\end{array}$} & \multirow{2}{*}{$\begin{array}{c}\text { Acute or } \\
\text { Lethal } \\
\text { Dose/Conc. }\end{array}$} & \multirow{2}{*}{$\begin{array}{c}L_{50} \text { or } \\
L^{2} C_{50}\end{array}$} \\
\hline & & Dose or Conc. ${ }^{b}$ & Effect & & & \\
\hline Hexachlorobenzene & Japanese quail & $20 \mathrm{ppm}(90 \mathrm{~d})$ & reproduction & & & \\
\hline Hexachlorobenzene & Japanese quail & . & & & $\begin{array}{l}1 \mathrm{ppm} \\
(90 \mathrm{~d}) \\
\end{array}$ & \\
\hline Hexachlorobenzene & mallard duck & & $30 \%$ mortality & & $5000 \mathrm{ppm}$ & $>5000 \mathrm{ppm}$ \\
\hline Hexachlorobutadiene & Japanese quail & $0.3 \mathrm{ppm}(90 \mathrm{~d})$ & & & & \\
\hline Hexachlorophene & rat & 100 ppm (3 gen.) & reproduction & 20 ppm (3 gen.) & & \\
\hline $\begin{array}{l}\text { Hexamethylphosphoric } \\
\text { triamide }\end{array}$ & rat & $\begin{array}{l}2 \mathrm{mg} / \mathrm{kg} / \mathrm{d}(169 \\
\text { d) }\end{array}$ & reproduction & & & \\
\hline Iodine & mule deer & $\begin{array}{l}200 \mathrm{UC}(1 \mathrm{x} / \mathrm{mo} . \\
7 \mathrm{mo})\end{array}$ & $\begin{array}{l}\text { accum. in } \\
\text { thyroid }\end{array}$ & & & \\
\hline Kepone & Japanese quail & & & & $\begin{array}{r}200 \mathrm{ppm} \\
(240 \mathrm{~d}) \\
\end{array}$ & \\
\hline Kepone & Japanese quail & & & & & \\
\hline Lead & bobwhite quail & & & $\begin{array}{l}2000 \mathrm{ppm}(6 \\
\mathrm{wk})\end{array}$ & & \\
\hline Lead acetate & Japanese quail & $1 \mathrm{ppm}(12 \mathrm{wk})$ & reproductiion & & & \\
\hline Lead acetate & bobwhite quail & $1000 \mathrm{ppm}(6 \mathrm{wk})$ & growth & & & \\
\hline Lead arsenate & rat & & & & & $1545 \mathrm{mg} / \mathrm{kg}$ \\
\hline Lead arsonate & Japanese quail & & & & & $4185 \mathrm{ppm}(5 \mathrm{~d})$ \\
\hline Lead arsonate & $\begin{array}{l}\text { ring-necked } \\
\text { pheasant }\end{array}$ & & & & & 4989 ppm (5 d) \\
\hline
\end{tabular}




\begin{tabular}{|c|c|c|c|c|c|c|}
\hline \multicolumn{7}{|c|}{ Selected toxicity data for avian and mammalian wildlife ${ }^{\mathrm{a}}$} \\
\hline \multirow[b]{2}{*}{ Chemical } & \multirow[b]{2}{*}{ Species } & \multicolumn{2}{|c|}{ LOAEL } & \multirow{2}{*}{$\frac{\text { NOAEL }}{\text { Dose or Conc. }^{b}}$} & \multirow{2}{*}{$\begin{array}{l}\text { Acute or } \\
\text { Lethal } \\
\text { Dose/Conc. }\end{array}$} & \multirow{2}{*}{$\begin{array}{c}\mathrm{LD}_{50} \text { or } \\
\mathrm{LC}_{s 0}\end{array}$} \\
\hline & & Dose or Conc. & Effect & & & \\
\hline Lead, tetraethyl & mallard duck & & & & $6 \mathrm{mg} / \mathrm{kg}$ & \\
\hline Lithium chloride & $\begin{array}{l}\text { red-winged } \\
\text { blackbird }\end{array}$ & & & & $\begin{array}{c}15,000 \mathrm{ppm} \\
(4 \mathrm{~d})\end{array}$ & \\
\hline Magnesium & Japanese quail & $\begin{array}{l}1500 \mathrm{ppm} \\
(2 \mathrm{wk})\end{array}$ & physiol. & $\begin{array}{l}1000 \mathrm{ppm} \\
(2 \mathrm{wk})\end{array}$ & & \\
\hline Mercuric chloride & Japanese quail & & & $2 \mathrm{ppm}(1 \mathrm{yr})$ & & \\
\hline Mercuric chloride & Japanese quail & $4 \mathrm{ppm}(12 \mathrm{wk})$ & physiol. & $2 \mathrm{ppm}$ & & \\
\hline Mercuric chloride & chicken & $100 \mathrm{ppm}(8 \mathrm{wk})$ & reprod. & & & \\
\hline Mercuric sulfate & chicken & $100 \mathrm{ppm}(8 \mathrm{wk})$ & reprod. & & & \\
\hline Methyl mercury chloride & mallard duck & & & $5 \mathrm{ppm}(3 \mathrm{mo})$ & & \\
\hline Methyl mercuty chloride & chicken & $5 \mathrm{ppm}(8 \mathrm{wk})$ & reprod. & & & \\
\hline $\begin{array}{l}\text { Methyl mercury } \\
\text { dicyandiamide }\end{array}$ & mallard duck & $0.5 \mathrm{ppm}(1 \mathrm{yr})$ & reprod. & & & \\
\hline . & black duck & $\begin{array}{l}3 \mathrm{ppm} \\
(28 \mathrm{wk} / \mathrm{yr}, 2 \mathrm{yr})\end{array}$ & reprod. & & & \\
\hline $\begin{array}{l}\text { Monosodium } \\
\text { methanearsonate }\end{array}$ & $\begin{array}{l}\text { white-footed } \\
\text { mouse }\end{array}$ & $1000 \mathrm{ppm}(30 \mathrm{~d})$ & physiol. & & & $300 \mathrm{mg} / \mathrm{kg}$ \\
\hline $\begin{array}{l}\text { Octochlorodibenzo-p- } \\
\text { dioxin }\end{array}$ & rat & $\begin{array}{l}0.5 \mathrm{mg} / \mathrm{kg} \mathrm{(2} \\
\mathrm{wk})\end{array}$ & pathology & $\begin{array}{l}0.1 \mathrm{mg} / \mathrm{kg}(2 \\
\mathrm{wk})\end{array}$ & & \\
\hline $\begin{array}{l}\text { PBB } \\
\text { (hexabromobiphenyl) }\end{array}$ & Japanese quail & $100 \mathrm{ppm}(9 \mathrm{wk})$ & reprod. & $20 \mathrm{ppm}(9 \mathrm{wk})$ & & \\
\hline
\end{tabular}




\begin{tabular}{|c|c|c|c|c|c|c|}
\hline \multicolumn{7}{|c|}{ Selected toxicity data for avian and mammalian wildlife $\mathrm{e}^{\mathrm{a}}$} \\
\hline \multirow[b]{2}{*}{ Chemical } & \multirow[b]{2}{*}{ Species } & \multicolumn{2}{|c|}{ LOAEL } & \multirow{2}{*}{$\frac{\text { NOAEL }}{\text { Dose or Conc. }{ }^{b}}$} & \multirow{2}{*}{$\begin{array}{l}\text { Acute or } \\
\text { Lethal } \\
\text { Dose/Conc. }\end{array}$} & \multirow{2}{*}{$\begin{array}{l}\mathrm{LD}_{50} \text { or } \\
\mathrm{LC}_{50}\end{array}$} \\
\hline & & Dose or Conc. ${ }^{b}$ & Effect & & & \\
\hline $\begin{array}{l}\text { PBB (polybrominated } \\
\text { biphenyls }\end{array}$ & mink & $1 \mathrm{ppm}(10 \mathrm{mo})$ & reproduction & & & $\begin{array}{c}179 \mathrm{mg} / \mathrm{kg} \\
3.95 \mathrm{ppm}\end{array}$ \\
\hline PBB & Japanese quail & $25 \mathrm{ppm}(7 \mathrm{~d})$ & blood chem. & & & \\
\hline Sodium arsenite & mallard duck & $100 \mathrm{mg} / \mathrm{kg}(1 \mathrm{~d})$ & thin eggshells & & & \\
\hline Sodium cyanide & coyote & $4 \mathrm{mg} / \mathrm{kg}$ & physiol. & & & \\
\hline $\begin{array}{l}\text { Sodium } \\
\text { monofluoroacetate }\end{array}$ & mallard duck & & & & & $3.71 \mathrm{mg} / \mathrm{kg}$ \\
\hline " & mallard duck & & & & $9.11 \mathrm{mg} / \mathrm{kg}$ & \\
\hline " & $\begin{array}{l}\text { ring-necked } \\
\text { pheasant }\end{array}$ & & & & $6.46 \mathrm{mg} / \mathrm{kg}$ & \\
\hline * & chukar partridge & & & & $3.51 \mathrm{mg} / \mathrm{kg}$ & \\
\hline " & quail & & & & $17.7 \mathrm{mg} / \mathrm{kg}$ & \\
\hline$"$ & pigeon & & & & $4.24 \mathrm{mg} / \mathrm{kg}$ & \\
\hline " & house sparrow & & & & $3.00 \mathrm{mg} / \mathrm{kg}$ & \\
\hline$"$ & kit fox & & & & & $0.22 \mathrm{mg} / \mathrm{kg}$ \\
\hline Sodium nitrate & Japanese quail & & & & $3300 \mathrm{ppm}(7 \mathrm{~d})$ & \\
\hline Sodium nitrate & Japanese quail & & & & $\begin{array}{l}660 \mathrm{ppm}(15 \\
\mathrm{wk})\end{array}$ & \\
\hline Thallium sulfate & golden eagle & & & & & $120 \mathrm{mg} / \mathrm{kg}$ \\
\hline Tribromoethanol & mallard duck & & & & $150 \mathrm{mg} / \mathrm{kg}$ & \\
\hline
\end{tabular}




\begin{tabular}{|c|c|c|c|c|c|c|}
\hline \multicolumn{7}{|c|}{ Selected toxicity data for avian and mammalian wildlife $\mathrm{e}^{*}$} \\
\hline \multirow[b]{2}{*}{ Chemical } & \multirow[b]{2}{*}{ Species } & \multicolumn{2}{|c|}{ LOAEL } & \multirow{2}{*}{$\frac{\text { NOAEL }}{\text { Dose or Conc. }}$} & \multirow{2}{*}{$\begin{array}{l}\text { Acute or } \\
\text { Lethal } \\
\text { Dose/Conc. }\end{array}$} & \multirow{2}{*}{$\begin{array}{c}\mathrm{LD}_{s 0} \text { or } \\
\mathrm{LC}_{50}\end{array}$} \\
\hline & & Dose or Conc. ${ }^{b}$ & Effect & & & \\
\hline Vanadyl sulfate & mallard duck & $\begin{array}{r}100 \mathrm{ppm} \\
(12 \mathrm{wk})\end{array}$ & blood chem. & $10 \mathrm{ppm}$ (12 wk) & & \\
\hline Zinc phosphide & kit fox & & & & & $93 \mathrm{mg} / \mathrm{kg}$ \\
\hline Zinc phosphide & red fox & & & & $\begin{array}{c}10.64 \mathrm{mg} / \mathrm{kg} / \mathrm{d} \\
(3 \mathrm{~d})\end{array}$ & \\
\hline Zinc phosphide & grey fox & & & & $\begin{array}{l}8.6 \mathrm{mg} / \mathrm{kg} / \mathrm{d} \\
(3 \mathrm{~d})\end{array}$ & \\
\hline Zinc phosphide & great horned owl & & & & $\begin{array}{c}22.31 \mathrm{mg} / \mathrm{kg} / \mathrm{d} \\
(3 \mathrm{~d})\end{array}$ & \\
\hline
\end{tabular}

- Data extracted from TERRE-TOX database (Meyers and Schiller 1986). Complete citations for these data are not yet available.

- Dose in $\mathrm{mg} / \mathrm{kg} /$ day; dietary concentration in $\mathrm{ppm}$; water concentration in $\mathrm{mg} / \mathrm{L}$. 


\section{APPENDIX B}

NOAELs and LOAELs for Laboratory Animals 


\begin{tabular}{|c|c|c|c|c|c|c|c|}
\hline \multirow[b]{3}{*}{ Chemical } & \multirow[b]{3}{*}{ Species } & \multicolumn{5}{|c|}{ NOAELs and LOAELs for laboratory animals } & \multirow[b]{3}{*}{ References (LOAEL/NOAEL) } \\
\hline & & \multicolumn{2}{|c|}{ LOAEL } & \multirow[b]{2}{*}{ Effect } & \multicolumn{2}{|c|}{ NOAEL OR NOEL } & \\
\hline & & $\mathrm{mg} / \mathrm{kg}$ & $\begin{array}{l}\text { Concentration in } \\
\text { Diet" or Water }\end{array}$ & & $\mathrm{mg} / \mathrm{kg}$ & $\begin{array}{l}\text { Concentration in } \\
\text { Diet or Water }\end{array}$ & \\
\hline Acetone & rat & $500(90 \mathrm{~d})$ & & liver and kidney & $100(90 \mathrm{~d})$ & & EPA, 1986 \\
\hline \multirow{3}{*}{$\begin{array}{r}\text { Arsenic, inorganic } \\
\text { (trivalent) (as As) }\end{array}$} & mouse & & $5 \mathrm{mg} / \mathrm{L}$ (3 gen.) & decr. litter size & & & Schroeder and Mitchener, 1971 \\
\hline & rat & 4.88 & $62.5 \mathrm{ppm}(2 \mathrm{yr})$ & decr. growth & 2.44 & $31.3 \mathrm{ppm}(2 \mathrm{yr})$ & Byron et al., 1967 \\
\hline & $\operatorname{dog}$ & 3.1 & $125 \mathrm{ppm}(2 \mathrm{yr})$ & decr. survival & 1.25 & $50 \mathrm{ppm}(2 \mathrm{yr})$ & Byron et al., 1967 \\
\hline Barium & rat & $5.1(16 \mathrm{mo})$ & & cardiovascular & $0.51(16 \mathrm{mo})$ & & Perry et al., 1983 \\
\hline \multirow[t]{2}{*}{ Benzene } & rat & $100(103 \mathrm{wk})$ & & decr. survival & & & Huff et al., 1989 \\
\hline & rat & $25(103 \mathrm{wk})$ & & lymphocytopenia & & & Huff et al., 1989 \\
\hline Beryllium & rat & $443(83 d)$ & & $\begin{array}{l}\text { bone; } \\
\text { decr. wt }\end{array}$ & $0.54(1126 d)$ & $5 \mathrm{mg} / \mathrm{L}(1126 \mathrm{~d})$ & $\begin{array}{l}\text { Businco, 1940/Schroeder and } \\
\text { Mitchener, } 1975\end{array}$ \\
\hline Carbon tetrachloride & rat & $10(12 w k)$ & & liver, necrosis & $0.71(12 \mathrm{wk})$ & & Bruckner et al., 1986 \\
\hline Chlordane & mouse & $0.16(22 d)$ & & blood chem. & & & TERRE-TOX $(78,290,617)$ \\
\hline & & & & & & & \\
\hline
\end{tabular}




\begin{tabular}{|c|c|c|c|c|c|c|c|}
\hline \multirow[b]{3}{*}{ Chemical } & \multirow[b]{3}{*}{ Species } & \multicolumn{5}{|c|}{ NOAELs and LOAELs for laboratory animals } & \multirow[b]{3}{*}{ References (LOAEL/NOAEL) } \\
\hline & & \multicolumn{2}{|c|}{ LOAEL } & \multirow[b]{2}{*}{ Effect } & \multicolumn{2}{|c|}{ NOAEL OR NOEL } & \\
\hline & & $\mathrm{mg} / \mathrm{kg}$ & $\begin{array}{l}\text { Concentration in } \\
\text { Diet or Water }\end{array}$ & & $\mathrm{mg} / \mathrm{kg}$ & $\begin{array}{l}\text { Concentration in } \\
\text { Diet or Water }\end{array}$ & \\
\hline Chloroform & rat & $90(78 \mathrm{wk})$ & & kidney, testis & & & Reuber, 1979 \\
\hline Chloroform & $\operatorname{dog}$ & $12.9(7.5 \mathrm{yr})$ & & liver, fatty cysts & & & Heywood et al., 1979 \\
\hline Chromium - Ammonium chromate & & & & & $2.5(1 \mathrm{yr})$ & & \\
\hline Chromium VI & rat & & & & $2.4(2 \mathrm{yr})$ & & Mackenzie et al., 1958 \\
\hline Chromium - Chromic chloride & rat & & & & $38.3(25 \mathrm{wk})$ & & Kurokawa et al., 1985 \\
\hline Chromium - Potassium bichromate & rat & & & & $2.5(1 \mathrm{yr})$ & & Mackenzie et al., 1958 \\
\hline Chromium - Potassium chromate & rat & & & & $2.5(1 \mathrm{yr})$ & & Mackenzie et al., 1958 \\
\hline Chromium - Sodium chromate & rat & & & & $2.5(1 \mathrm{yr})$ & & Mackenzie et al., 1958 \\
\hline Cyanide & rat & & & & $10.8(104 \mathrm{wk})$ & & Howard and Hanzal, 1955 \\
\hline Cyanide & rat & 30 & & $\begin{array}{l}\text { decr. wt.; } \\
\text { nervous system; } \\
\text { thyroid }\end{array}$ & & & Philbrick et al., 1979 \\
\hline Cyanide - Chlorine cyanide & rat & & & $\begin{array}{l}\text { whole body; } \\
\text { thyroid; } \\
\text { nervous system }\end{array}$ & $25.3(2 \mathrm{yr})$ & & Howard and Hanzal, 1955 \\
\hline Cyanide - Copper cyanide & rat & & & & $5(90 \mathrm{~d})$ & & EPA, 1986 \\
\hline Cyanide - Hydrogen cyanide & rat & 31 & & $\begin{array}{l}\text { decr. wt; thyroid; } \\
\text { nervous system }\end{array}$ & & & Philbrick et al., 1979 \\
\hline Cyanide - Hydrogen cyanide & rat & & & & $11.2(2 \mathrm{yr})$ & & Howard and Hanzal, 1955 \\
\hline Cyanide - Potassium cyanide & rat & & & & $27(2 \mathrm{yr})$ & & Howard and Hanzal, 1955 \\
\hline
\end{tabular}




\begin{tabular}{|c|c|c|c|c|c|c|c|}
\hline \multirow[b]{3}{*}{ Chemical } & \multirow[b]{3}{*}{ Species } & \multicolumn{5}{|c|}{ NOAELs and LOAELs for laboratory animals } & \multirow[b]{3}{*}{ References (LOAEL/NOAEL) } \\
\hline & & \multicolumn{2}{|c|}{ LOAEL } & \multirow[b]{2}{*}{ Effect } & \multicolumn{2}{|c|}{ NOAEL OR NOEL } & \\
\hline & & $\mathrm{mg} / \mathrm{kg}$ & $\begin{array}{l}\text { Concentration in } \\
\text { Diet" or Water" } \\
\end{array}$ & & $\mathrm{mg} / \mathrm{kg}$ & $\begin{array}{l}\text { Concentration in } \\
\text { Diet" or Water } \\
\end{array}$ & \\
\hline $\begin{array}{l}\text { Cyanide - Potassium silver } \\
\text { cyanide }\end{array}$ & rat & & & & $82.7(2 \mathrm{yr})$ & & Howard and Hanzal, 1955 \\
\hline Cyanide - Silver cyanide & rat & & & & $55.7(2 \mathrm{yr})$ & & Howard and Hanzal, 1955 \\
\hline Cyanide - Sodium cyanide & rat & $\begin{array}{l}56 \\
\text { (subchronic) }\end{array}$ & & $\begin{array}{l}\text { decr. wt.; } \\
\text { thyroid; } \\
\text { nervous system }\end{array}$ & $\begin{array}{l}20.4(\mathrm{CN}) \\
(104 \mathrm{wk})\end{array}$ & & $\begin{array}{l}\text { Philbrick et al., 1979/Howard } \\
\text { and Hanzal, } 1955\end{array}$ \\
\hline Cyanide - Zinc cyanide & rat & & & $\begin{array}{l}\text { decr. wt.; } \\
\text { thyroid; } \\
\text { nervous system }\end{array}$ & $24.3(2 \mathrm{yr})$ & & Howard and Hanzal, 1955 \\
\hline 1,2-Dichloroethane & rat & & & ver, heart & $7.4(\leq 8 \mathrm{mo})$. & & $\begin{array}{l}\text { Heppel et al., 1946; Hofman et } \\
\text { al., 1971; Spencer et al., } 1951\end{array}$ \\
\hline 1,1-Dichloroethylene & rat & $9(2 \mathrm{yr})$ & & liver, histol. & & & Quast et al., 1983 \\
\hline $\begin{array}{l}\text { 1,2-Dichloroethylene, } \\
\text { mixed isomers }\end{array}$ & rat & & $500 \mathrm{mg} / \mathrm{L}$ & liver lesions & & & Quast et al., 1983 \\
\hline Ethyl acetate & rat & $3600(90 \mathrm{~d})$ & & decr. weight & $900(90 \mathrm{~d})$ & & EPA, 1986 \\
\hline Hexachlorocyclohexane & rat & & $0.9 \mathrm{ppp}(90 \mathrm{~d})$ & pathol. & & & TERRE-TOX $(78-290,620)$ \\
\hline
\end{tabular}




\begin{tabular}{|c|c|c|c|c|c|c|c|}
\hline \multirow[b]{3}{*}{ Chemical } & \multirow[b]{3}{*}{ Species } & \multicolumn{5}{|c|}{ NOAELs and LOAELs for laboratory animals } & \multirow[b]{3}{*}{ References (LOAEL/NOAEL) } \\
\hline & & \multicolumn{2}{|c|}{ LOAEL } & \multirow[b]{2}{*}{ Effect } & \multicolumn{2}{|c|}{ NOAEL OR NOEL } & \\
\hline & & $\mathrm{mg} / \mathrm{kg}$ & $\begin{array}{l}\text { Concentration in } \\
\text { Diet" or Water }\end{array}$ & & $\mathrm{mg} / \mathrm{kg}$ & $\begin{array}{l}\text { Concentration in } \\
\text { Diet" or Water }\end{array}$ & \\
\hline Kepone & mouse & $\begin{array}{l}12 \\
(10 \mathrm{~d} \text { gest. })\end{array}$ & & fetal mortality & & & TERRE-TOX $(76-290,614)$ \\
\hline Lead acetate & rat & $0.29(30 \mathrm{~d})$ & & testicular damage & & & Hillerbrand et al., 1973 \\
\hline Managanese & human & & & & 0.14 & & Schroeder et al., 1966 \\
\hline Mercuric chloride & rat & $0.64(39 \mathrm{wk})$ & & $\begin{array}{l}\text { immune syst.; } \\
\text { kidney }\end{array}$ & & & Knoflach et al., 1986 \\
\hline Mercuric sulfide & mouse & & & & 13.3 & & Revis et al., 1989 \\
\hline Mercury, methyl & human & 0.2 & & nervous system & & & SWG, 1971 \\
\hline Methanol & rat & $2500(90 \mathrm{~d})$ & & blood chem. & $500(90 \mathrm{~d})$ & & EPA, 1986 \\
\hline Methanol & rat & 2.5 (gest.) & $0.0002 \mathrm{mg} / \mathrm{L}$ & $\begin{array}{l}\text { behavior } \\
\text { (neonates) }\end{array}$ & & & Infurna and Weiss, 1986 \\
\hline Methylene chloride & rat & $\begin{array}{l}52.58 \\
(2 \mathrm{yr}) \\
\end{array}$ & & liver, histol. & $5.85(2 \mathrm{yr})$ & & NCA, 1982 \\
\hline $\begin{array}{l}\text { Methyl ethyl ketone (inhalation } \\
\text { data) }\end{array}$ & rat & & & & $92(12 \mathrm{wk})$ & & Labelle and Brieger, 1955 \\
\hline
\end{tabular}




\begin{tabular}{|c|c|c|c|c|c|c|c|}
\hline \multirow[b]{3}{*}{ Chemical } & \multirow[b]{3}{*}{ Species } & \multicolumn{5}{|c|}{ NOAELs and LOAELs for laboratory animals } & \multirow[b]{3}{*}{ References (LOAEL/NOAEL) } \\
\hline & & \multicolumn{2}{|c|}{ LOAEL } & \multirow[b]{2}{*}{ Effect } & \multicolumn{2}{|c|}{ NOAEL OR NOEL } & \\
\hline & & $\mathrm{mg} / \mathrm{kg}$ & $\begin{array}{l}\text { Concentration in } \\
\text { Diet or Water } \\
\end{array}$ & & $\mathrm{mg} / \mathrm{kg}$ & $\begin{array}{l}\text { Concentration in } \\
\text { Diet }^{*} \text { or Water } \\
\end{array}$ & \\
\hline 4-Methyl-2-pentanone & rat & & & liver; kidney & $50(13 \mathrm{wk})$ & & $\begin{array}{l}\text { Microbiological Associates, } \\
1986\end{array}$ \\
\hline Nitrate & human & $\begin{array}{l}1.8-3.2 \\
(\leq 8 \mathrm{mo})\end{array}$ & & $\begin{array}{l}\text { methemo- } \\
\text { glohinemia }\end{array}$ & $1.6(\leq 8 \mathrm{mo})$ & & Bosch et al., 1950 \\
\hline o-Phenylphenol & rat & $300(10 \mathrm{~d})$ & & & & & TERRE-TOX $(78-290,623)$ \\
\hline PCBs (Aroclor 1248) & monkey & & $2.5 \mathrm{ppm}(18 \mathrm{mo})$ & reprod. & & & TERRE-TOX $(79-290,315)$ \\
\hline PCBs (Aroclor 1248) & $\begin{array}{l}\text { monkey } \\
\text { (young) }\end{array}$ & & $0.154 \mathrm{ppm}(4 \mathrm{mo})$ & lethal & & & TERRE-TOX $(79-290,315)$ \\
\hline PCBs (Aroclor 1254) & rat & $>1.0$ & $>20$ ppm (2 gen.) & decr. litter size & $<0.25$ & $<5$ ppm (2 gen.) & Linder et al., 1974 \\
\hline PCBs (Aroclor 1254) & rabbit & & & fetotoxicity & 10 (gest) & & Villeneuve et al., 1971 \\
\hline N-Nitrosodipropylamine & rat & & $\mathrm{mg} / \mathrm{L}(30 \mathrm{wk})$ & lung, inflamm. & & & Lijinsky and Reuber, 1981a \\
\hline p-Nitrosodiphenylamine & mouse & & $4254 \mathrm{ppm}(57 \mathrm{wk})$ & liver & & & $\mathrm{NCl}, 1979 \mathrm{~b}$ \\
\hline & rat & & & & & $\begin{array}{l}5000 \text { ppm (long- } \\
\text { term) }\end{array}$ & NCI, 1979b \\
\hline Strontium (stable) & rat & & & rachitic changes & $263.1(3 \mathrm{yr})$ & & Skoryna, 1981 \\
\hline
\end{tabular}




\begin{tabular}{|c|c|c|c|c|c|c|c|}
\hline \multirow[b]{3}{*}{ Chemical } & \multirow[b]{3}{*}{ Species } & \multicolumn{5}{|c|}{ NOAELs and LOAELs for laboratory animals } & \multirow[b]{3}{*}{ References (LOAEL/NOAEL) } \\
\hline & & \multicolumn{2}{|c|}{ LOAEL } & \multirow[b]{2}{*}{ Effect } & \multicolumn{2}{|c|}{ NOAEL OR NOEL } & \\
\hline & & $\mathrm{mg} / \mathrm{kg}$ & $\begin{array}{l}\text { Concentration in } \\
\text { Diet or Water }\end{array}$ & & $\mathrm{mg} / \mathrm{kg}$ & $\begin{array}{l}\text { Concentration in } \\
\text { Diet or Water }\end{array}$ & \\
\hline 1,1,2,2-Tetrachloroethylene & mouse & $300(78 \mathrm{wk})$ & & liver & & & NCI, 1977 \\
\hline 1,1,2,2-Tetrachloroethylene & mouse & $71(6 \mathrm{wk})$ & & $\begin{array}{l}\text { incr. liver wt. } \\
\text { and triglycerides }\end{array}$ & $14(6 \mathrm{wk})$ & & Buben and O'Flaherty, 1985 \\
\hline Toluene & rat & 446 (13 wk) & & incr. organ wts. & $223(13 \mathrm{wk})$ & & NTP, 1989 \\
\hline 1,1,1-Trichloroethane & rat & 750 (78 wk) & & decr. survival & 350 (12 wk) & & $\begin{array}{l}\text { NCI, 1977/ Bruckner et al., } \\
1985\end{array}$ \\
\hline 1,1,1-Trichloroethane & g.pig & & & liver & & $500 \mathrm{ppm}$ & Torkelson et al., 1958 \\
\hline Trichloroethylene & rat & 150 (2 gen.) & & decr. litter size & 75 & & NTP, 1986 \\
\hline Trichloroethylene & mice & 300 ( 2 gen.) & & $\begin{array}{l}\text { decr. neonate } \\
\text { survival }\end{array}$ & 150 & & NTP, 1985 \\
\hline Uranium (soluble salts) & rabbit & $2.8(30 \mathrm{~d})$ & & kidney, histol. & & & Maynard and Hodge, 1949 \\
\hline Vinyl choride & rat & $1.3(149 \mathrm{wk})$ & & $\begin{array}{l}\text { decr. survival; } \\
\text { liver }\end{array}$ & 0.13 & & Dow Chemical Co., 1984 \\
\hline
\end{tabular}




\section{APPENDIX C}

List of Common Species of Mammals ${ }^{\mathrm{c}-1}$ and Birds ${ }^{\mathrm{c}-2}$ on the Oak Ridge Reservation 


\begin{tabular}{|c|c|c|c|c|c|}
\hline Group/Species & Scientific Name & $\begin{array}{c}\text { Body Weight } \\
\text { (g) }\end{array}$ & $\begin{array}{c}\text { Food } \\
\text { Intake }\end{array}$ & $\begin{array}{l}\text { Water } \\
\text { Intake }\end{array}$ & References \\
\hline$\frac{\text { Shrews and moles: }}{\text { Short-tailed shrew }}$ & Blarina brevicauda & $\begin{array}{l}14-29 \\
11\end{array}$ & $0.49 \mathrm{~g} / \mathrm{g}$ & $\begin{array}{l}0.223 \mathrm{~g} / \mathrm{g} \\
125 \mathrm{~mL} / \mathrm{d}\end{array}$ & $\begin{array}{l}\text { Whitaker, } \\
1980 \\
\text { Talmage, } \\
1989\end{array}$ \\
\hline Eastern mole & Scalopus aquaticus & $82-140$ & & & $\begin{array}{l}\text { Whitaker, } \\
1980\end{array}$ \\
\hline$\frac{\text { Rodents: }}{\text { Pine vole }}$ & Microtus pinetorum & $\begin{array}{l}25-39 \\
20-30\end{array}$ & & $\begin{array}{l}5.5 \\
\mathrm{~mL} / \mathrm{d} ; \\
1.8 \mathrm{~mL} / \mathrm{d}\end{array}$ & $\begin{array}{l}\text { Whitaker, } \\
1980 \\
\text { ASM, } \\
1969-92 \\
\text { Chew, } 1965\end{array}$ \\
\hline Prairie vole & Microtus ochrogaster & $37-48$ & & & $\begin{array}{l}\text { Whitaker, } \\
1980\end{array}$ \\
\hline Meadow vole & $\begin{array}{l}\text { Microtus } \\
\text { pennsylvanicus }\end{array}$ & $\begin{array}{l}20-70 \text {; } \\
44.2 \text { (avg., m), } \\
44.0 \text { (avg., f) }\end{array}$ & & $\begin{array}{l}0.21 \\
\mathrm{~mL} / \mathrm{g} \\
0.002 \\
\mathrm{~mL} / \mathrm{d}\end{array}$ & $\begin{array}{l}\text { Whitaker, } \\
1980 \\
\text { ASM, } \\
1969-92 \\
\text { Laughlin et } \\
\text { al., } 1975\end{array}$ \\
\hline White-footed mouse & Peromyscus leucopus & $\begin{array}{l}\text { 10-43; } \\
22 \text { (avg., TN) }\end{array}$ & & $3 \mathrm{~mL} / \mathrm{d}$ & $\begin{array}{l}\text { Whitaker, } \\
1980 \\
\text { Talmage, } \\
1989 \\
\text { Getz, } 1968\end{array}$ \\
\hline Golden mouse & Peromyscus nuttalli & $68-93$ & & & $\begin{array}{l}\text { Whitaker, } \\
1980\end{array}$ \\
\hline Eastern harvest mouse & $\begin{array}{l}\text { Reithrodontomys } \\
\text { humulis }\end{array}$ & $10-15$ & & & $\begin{array}{l}\text { Whitaker, } \\
1980\end{array}$ \\
\hline House mouse & Mus musculus & $18-23$ & & & $\begin{array}{l}\text { Whitaker, } \\
1980\end{array}$ \\
\hline Cotton rat & Sigmodon hispidus & $\begin{array}{l}80-120 \\
110-225(\mathrm{~m}) \\
100-200(\mathrm{f})\end{array}$ & & $23 \mathrm{~mL} / \mathrm{d}$ & $\begin{array}{l}\text { Whitaker, } \\
\text { 1980 ASM, } \\
\text { 1969-92 }\end{array}$ \\
\hline
\end{tabular}




\begin{tabular}{|c|c|c|c|c|c|}
\hline Group/Srecies & Scientific Name & $\begin{array}{c}\text { Body Weight } \\
\text { (g) }\end{array}$ & $\begin{array}{c}\text { Food } \\
\text { Intake }\end{array}$ & $\begin{array}{l}\text { Water } \\
\text { Intake }\end{array}$ & References \\
\hline Norway rat & Rattus norvegicus & $195-485$ & & $21 \mathrm{~mL} / \mathrm{d}$ & $\begin{array}{l}\text { Whitaker, } \\
1980 \\
\text { Chew, } 1965\end{array}$ \\
\hline Eastern chipmunk & Tamias striatus & $66-139$ & & & $\begin{array}{l}\text { Whitaker, } \\
1980\end{array}$ \\
\hline Gray squirrel & Sciurus carolinensis & $400-710$ & & & $\begin{array}{l}\text { Whitaker, } \\
1980\end{array}$ \\
\hline Muskrat & Ondatra zibethica & $\begin{array}{l}541-1,816 \\
700-1,800\end{array}$ & & & $\begin{array}{l}\text { Whitaker, } \\
1980 \\
\text { ASM, } \\
1969-92 \\
\end{array}$ \\
\hline$\frac{\text { Rabbits: }}{\text { Eastern cottontail }}$ & Sylvilagus floridanus & $\begin{array}{l}900-1800 ; \\
1134 \text { (avg., m) } \\
1244 \text { (avg., f) }\end{array}$ & & & $\begin{array}{l}\text { Whitaker, } \\
1980 \\
\text { ASM. } \\
1969-92\end{array}$ \\
\hline$\frac{\text { Marmotes: }}{\text { Woodchuck }}$ & Marmota monax & $2000-6400$ & & & $\begin{array}{l}\text { Whitaker, } \\
1980\end{array}$ \\
\hline$\frac{\text { Marsupials: }}{\text { Opossum }}$ & Didelphis marsupialis & $1800-6300$ & & & $\begin{array}{l}\text { Whitaker, } \\
1980\end{array}$ \\
\hline $\begin{array}{l}\text { Skunks, mink and } \\
\text { weasel: } \\
\text { Striped skunk }\end{array}$ & Mephitis mephitis & $2700-6300$ & & & $\begin{array}{l}\text { Whitaker, } \\
1980\end{array}$ \\
\hline Mink & Mustela vison & $700-1600$ & & $175 \mathrm{~mL} / \mathrm{d}$ & $\begin{array}{l}\text { Whitaker, } \\
1980 \\
\text { Eriksson et } \\
\text { al., } 1984 \\
\end{array}$ \\
\hline$\frac{\text { Bats: }}{\text { Red bat }}$ & Lasiurus borealis & $9.5-15$ & & & $\begin{array}{l}\text { Whitaker, } \\
1980\end{array}$ \\
\hline Big brown bat & Eptesicus fuscus & $13-18$ & & & $\begin{array}{l}\text { Whitaker, } \\
1980\end{array}$ \\
\hline$\frac{\text { Raccoons: }}{\text { Raccoon }}$ & Procyon lotor & $\begin{array}{l}5400-21,600 \\
6170 \text { (avg., m, MI) }\end{array}$ & & & $\begin{array}{l}\text { Whitaker, } \\
1980 \\
\text { ASM, } \\
1969-92\end{array}$ \\
\hline
\end{tabular}

\section{C-3}




\begin{tabular}{|c|c|c|c|c|c|}
\hline Group/Species & Scientific Name & $\begin{array}{c}\text { Body Weight } \\
\text { (g) }\end{array}$ & $\begin{array}{c}\text { Food } \\
\text { Intake }\end{array}$ & $\begin{array}{l}\text { Water } \\
\text { Intake }\end{array}$ & References \\
\hline$\frac{\text { Fox, coyote, and wolves: }}{\text { Red fox }}$ & Vulpes fulva & $3600-6800$ & & & $\begin{array}{l}\text { Whitaker, } \\
1980\end{array}$ \\
\hline Gray fox & $\begin{array}{l}\text { Urocyon } \\
\text { cineroargenteus }\end{array}$ & $3300-5900$ & & & $\begin{array}{l}\text { Whitaker, } \\
1980\end{array}$ \\
\hline Coyote & Canis latrans & $\begin{array}{l}8000-20,000(\mathrm{~m}), \\
7000-18,000 \text { (f); } \\
16,750 \text { (avg. m, } \\
\text { TX) } \\
13,620 \text { (avg., f, } \\
\text { TX) }\end{array}$ & & & $\begin{array}{l}\text { ASM, } \\
1969-92\end{array}$ \\
\hline Red wolf & Canis fufus & $\begin{array}{l}27,623 \text { (avg, m) } \\
21,591 \text { (avg, f) }\end{array}$ & & & $\begin{array}{l}\text { ASM, } \\
1969-92 \\
\end{array}$ \\
\hline$\frac{\text { Cats: }}{\text { Bobcat }}$ & Felis rufus & $6400-3100$ & & & $\begin{array}{l}\text { Whitaker, } \\
1980\end{array}$ \\
\hline$\frac{\text { Deer: }}{\text { Whitetail deer }}$ & $\begin{array}{l}\text { Odocoileus } \\
\text { virginianus }\end{array}$ & $\begin{array}{l}68,000 \text { (avg., m) } \\
45,000 \text { (avg., f) }\end{array}$ & & & $\begin{array}{l}\text { ASM, } \\
1969-92\end{array}$ \\
\hline
\end{tabular}




\begin{tabular}{|c|c|c|c|c|c|}
\hline Group/Species & Sex & Scientific Name & $\begin{array}{c}\mathbf{B} \mathbf{W}^{\mathbf{b}} \\
\mathbf{( g )}\end{array}$ & $\begin{array}{l}\text { Food }^{\boldsymbol{c}} \\
\text { Intake } \\
\text { (g/day) }\end{array}$ & $\begin{array}{l}\text { Water } \\
\text { Intake } \\
\text { (ml/day) }\end{array}$ \\
\hline \multicolumn{6}{|l|}{ Upland Birds: } \\
\hline \multirow[t]{2}{*}{ Wild Turkey } & $\mathbf{F}$ & Meleagris gallipavo & 4222 & 148.52 & 154.86 \\
\hline & $\mathbf{M}$ & & 7400 & 214.02 & 225.55 \\
\hline Bobwhite quail & Both & Colinus virginianus & 178 & 18.91 & 18.56 \\
\hline \multirow[t]{2}{*}{ Ruffed grouse } & $\mathbf{F}$ & Bonasa umbellus & 532 & 38.56 & 38.66 \\
\hline & $\mathbf{M}$ & & 621 & 42.65 & 42.88 \\
\hline \multirow[t]{2}{*}{ Mourning dove } & $\mathrm{F}$ & Zenaida macroura & 115 & 14.23 & 13.85 \\
\hline & $\mathbf{M}$ & & 123 & 14.86 & 14.49 \\
\hline Domestic pigeon & Both & Columba livia & 542 & 39.03 & 39.14 \\
\hline \multirow[t]{2}{*}{ Killdeer } & $\mathrm{F}$ & Charadrius vociferus & 101 & 13.07 & 12.70 \\
\hline & $\mathbf{M}$ & & 92.1 & 12.31 & 11.93 \\
\hline \multirow[t]{2}{*}{ American woodcock } & $\mathrm{F}$ & Philohela minor & 219 & 21.64 & 21.33 \\
\hline & $\mathbf{M}$ & & 176 & 18.77 & 18.42 \\
\hline \multicolumn{6}{|l|}{ Waterfowl: } \\
\hline \multirow[t]{2}{*}{ Black duck } & $\mathbf{F}$ & Anas rubripes & 1100 & 61.88 & 62.89 \\
\hline & $\mathbf{M}$ & & 1400 & 72.39 & 73.92 \\
\hline Mallard duck & Both & Anas platyrhychos & 1082 & 61.21 & 62.20 \\
\hline \multirow[t]{2}{*}{ Blue-winged teal } & $\mathbf{F}$ & Anas discors & 363 & 30.07 & 29.92 \\
\hline & $\mathbf{M}$ & & 409 & 32.49 & 32.41 \\
\hline \multirow[t]{2}{*}{ Canadian goose } & $\mathrm{F}$ & Branta canadensis & 3314 & 126.86 & 131.67 \\
\hline & $\mathbf{M}$ & & 3814 & 139.01 & 144.67 \\
\hline \multirow[t]{2}{*}{ American coot } & $\mathbf{F}$ & Fulica americana & 560 & 39.87 & 40.01 \\
\hline & $\mathbf{M}$ & & 724 & 47.13 & 47.52 \\
\hline \multirow[t]{2}{*}{ Wood duck } & $\mathrm{F}$ & Aix sponsa & 635 & 43.27 & 43.52 \\
\hline & $\mathbf{M}$ & & 681 & 45.28 & 45.61 \\
\hline
\end{tabular}




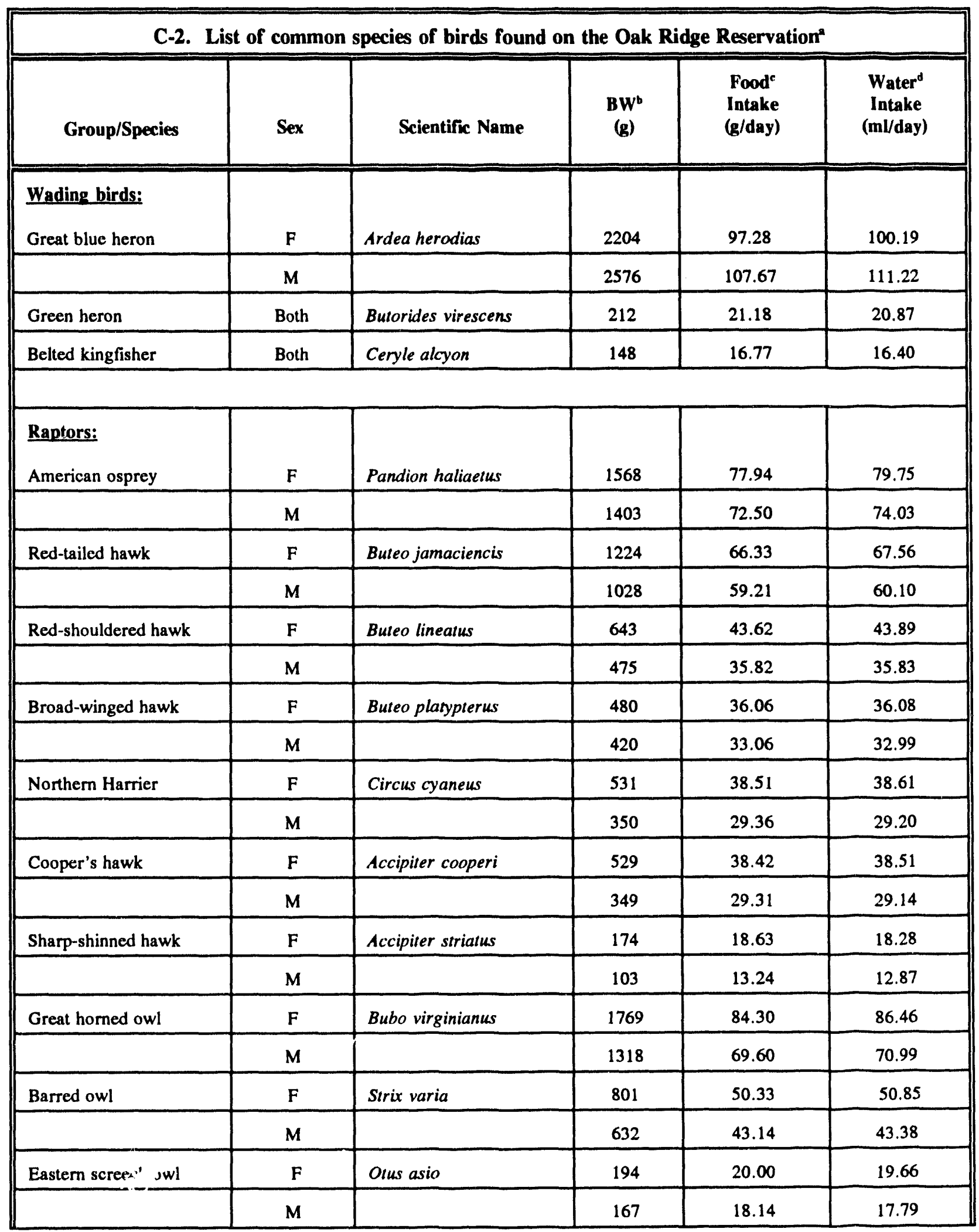




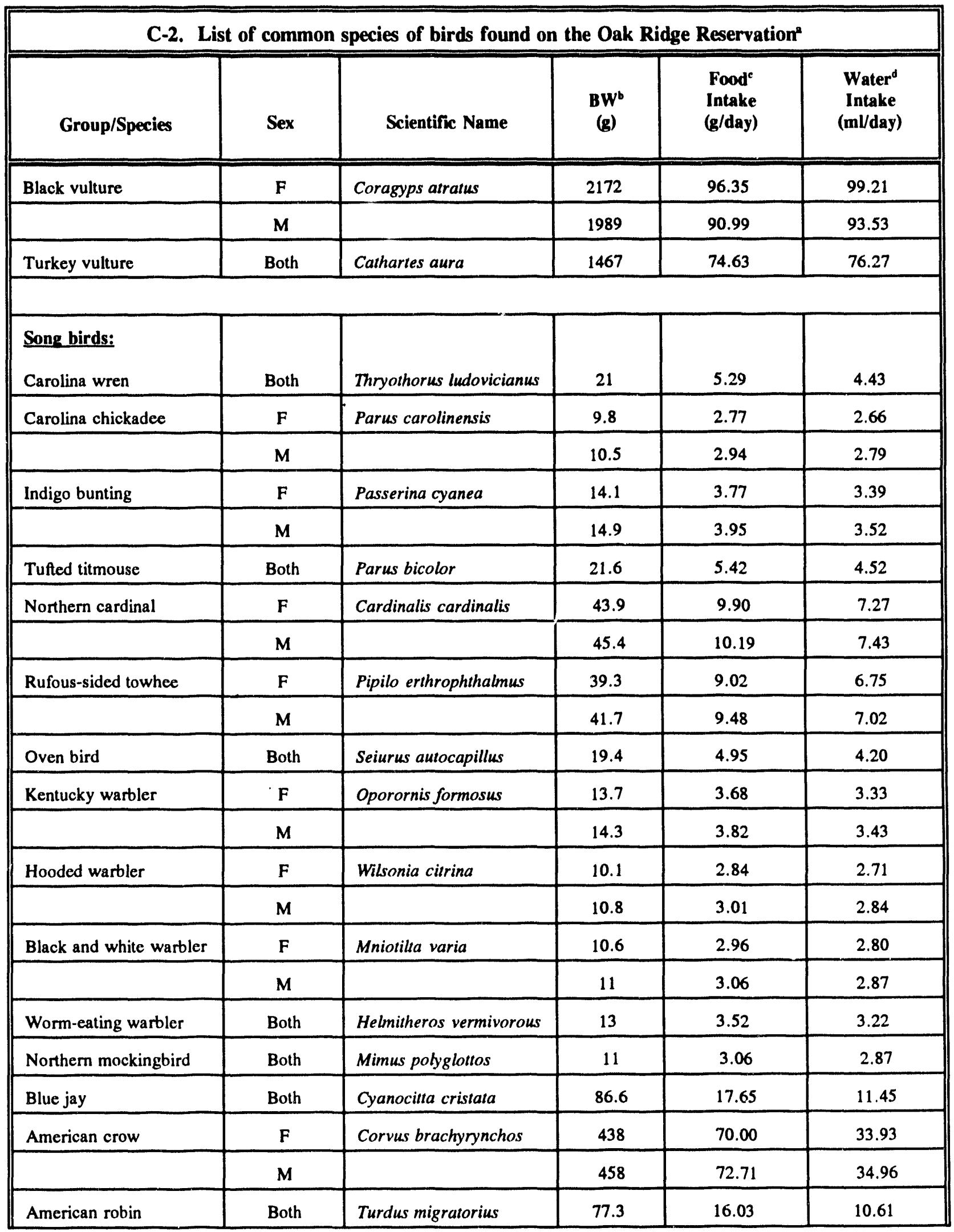

C-7 


\begin{tabular}{|c|c|c|c|c|c|}
\hline Group/Species & Sex & Scientific Name & $\begin{array}{c}\mathbf{B W} \\
(\mathbf{g})\end{array}$ & $\begin{array}{l}\text { Food }^{\mathrm{e}} \\
\text { Intake } \\
\text { (g/day) }\end{array}$ & $\begin{array}{l}\text { Water } \\
\text {-Intake } \\
\text { (ml/day) }\end{array}$ \\
\hline Wood thrush & Both & Hylocicla mustelina & 47.4 & 10.58 & 7.65 \\
\hline \multirow[t]{2}{*}{ European starling } & $\mathbf{F}$ & Sturnus vulgaris & 79.9 & 16.48 & 10.85 \\
\hline & $\mathbf{M}$ & & 84.7 & 17.32 & 11.29 \\
\hline \multirow[t]{2}{*}{ Common grackle } & $\mathbf{F}$ & Qusiculus quiscula & 100 & 19.95 & 12.61 \\
\hline & $\mathbf{M}$ & & 127 & 24.44 & 14.80 \\
\hline \multirow[t]{2}{*}{ Brown-headed cowbird } & $\mathbf{F}$ & Molothrus ater & 38.8 & 8.92 & 6.69 \\
\hline & $\mathbf{M}$ & & 49.9 & 11.0 & 7.92 \\
\hline \multirow[t]{2}{*}{ Song sparrow } & $\mathbf{F}$ & Melospiza melodia & 20.5 & 5.19 & 4.36 \\
\hline & $\mathbf{M}$ & & 21 & 5.29 & 4.43 \\
\hline Field sparrow & Both & Spizella pusilla & 12.5 & 3.41 & 3.13 \\
\hline Chipping sparrow & Both & Spizella passerina & & & \\
\hline \multirow[t]{2}{*}{ House sparrow } & $\mathbf{F}$ & Passer domesticus & 27.4 & 6.63 & 5.29 \\
\hline & $\mathbf{M}$ & & 28 & 6.76 & 5.37 \\
\hline \multirow[t]{2}{*}{ Red-winged blackbird } & $\mathbf{F}$ & Agelaius phoeniceus & 41.5 & 9.45 & 7.00 \\
\hline & $\mathbf{M}$ & & 63.6 & 13.58 & 9.31 \\
\hline \multirow[t]{2}{*}{ Common Yellowthroat } & $\mathbf{F}$ & Geothlypis trichas & 9.9 & 2.79 & 2.68 \\
\hline & $\mathbf{M}$ & & 10.3 & 2.89 & 2.75 \\
\hline \multirow[t]{2}{*}{ Yellow-breasted chat } & $\mathrm{F}$ & Icteria virens & 25.1 & 6.16 & 5.00 \\
\hline & $\mathbf{M}$ & & 25.5 & 6.24 & 5.05 \\
\hline White-eyed vireo & Both & Vireo griseus & 11.4 & 3.15 & 2.94 \\
\hline
\end{tabular}

- Source: Clinch River Breeder Reactor, EIS, 1976-79.

' Source: Dunning 1984.

c Calculated using Equation 13 (Equation 14 for songbirds).

${ }^{d}$ Calculated using Equation 20. 


\section{DISTRIBUTION}
1. A. Armstrong
2. L. D. Bates
3. L. Barnthouse
4. G. Blaylock
5. R. Bonczek
6. R. Brothers
7. P. Cline
8. P. Cole
9. D. Cox
10. P. Cross
11. M. Daniel
12. K. Daniels
13. J. Dee
14. K. Eckerman
15. M. Ferre
16. J. Guty
17. C. D. Goins
18. B. Haas
19. D. Halbrook
20. P. J. Halsey
21. S. Horsewood
22. R. Hull
23. D. Jones
24. R. King
25. D. Kocher
26. R. Kramel
27. J. Kuhaida
28. B. Ladd
29. R. Mathis
30. C. W. McGinn
31. D. Mentzer
32. P.D. Miller
33. D.B. Miller
34. B. Montgomery
35. R. Moody

36. B. Nourse

78. Office of Assistant Manager for Energy Research and Development, DOE Oak Ridge Field Office, P.O. Box 2001, Oak Ridge, TN 37831-8600.

79-80. R. L. Nace, DOE, Office of Environmental Restoration, Office of Eastern Area Programs, Oak Ridge Program Division, Washington, DC 20585-0002.

81-82. R. C. Sleeman, DOE Oak Ridge Field Office, P.O. Box 2001, Oak Ridge, TN, 37831-8540.

83-84. J. T. Sweeney, DOE Oak Ridge Field Office, P.O. Box 2001, Oak Ridge, TN, 37831-8541.

85. S. P. Riddle, DOE Oak Ridge Field Office, P.O. Box 2001, Oak Ridge, TN, 37831-8541.

86. D. W. Swindle, Radian Corporation, 120 South Jefferson Circle, Oak Ridge, TN, 37830.

87-88. Office of Scientific and Technical Information, P.O. Box 62, Oak Ridge, TN, 37831.

89. B. Cornaby, SAIC, Box 2501, 301 Laboratory Road, Oak Ridge, TN, 37831.

90-95. D. McCoy, TDEC, 761 Emory Valley Rd, Oak Ridge, TN, 37831.

96. L. Wellman, EPA Region IV, WFMD/OHA, 345 Courtland St. N.E., Atlanta, GA, 30365.

97. S. Norton, EPA, RD-689, 401 M St. S.W. (WH-586), Washington, D.C., 20460.

98. C. Nolt, EPA, Office of Water, 401 M St. S.W. (WH-586), Washington, D.C., 20460.

99. E. Will, 648 Robertsville Rd, Oak Ridge, TN, 37831.

100. L. Griffin, Forestal Building, EH221, 1000 Independence Ave. U.W., Washington, D.C., 20585.

101-102. S. Dyer and L. Haselow, Westinghouse, Savannah River Co. 1992 S. Centennial Ave., Building 4, Aiken, SC, 29803. 

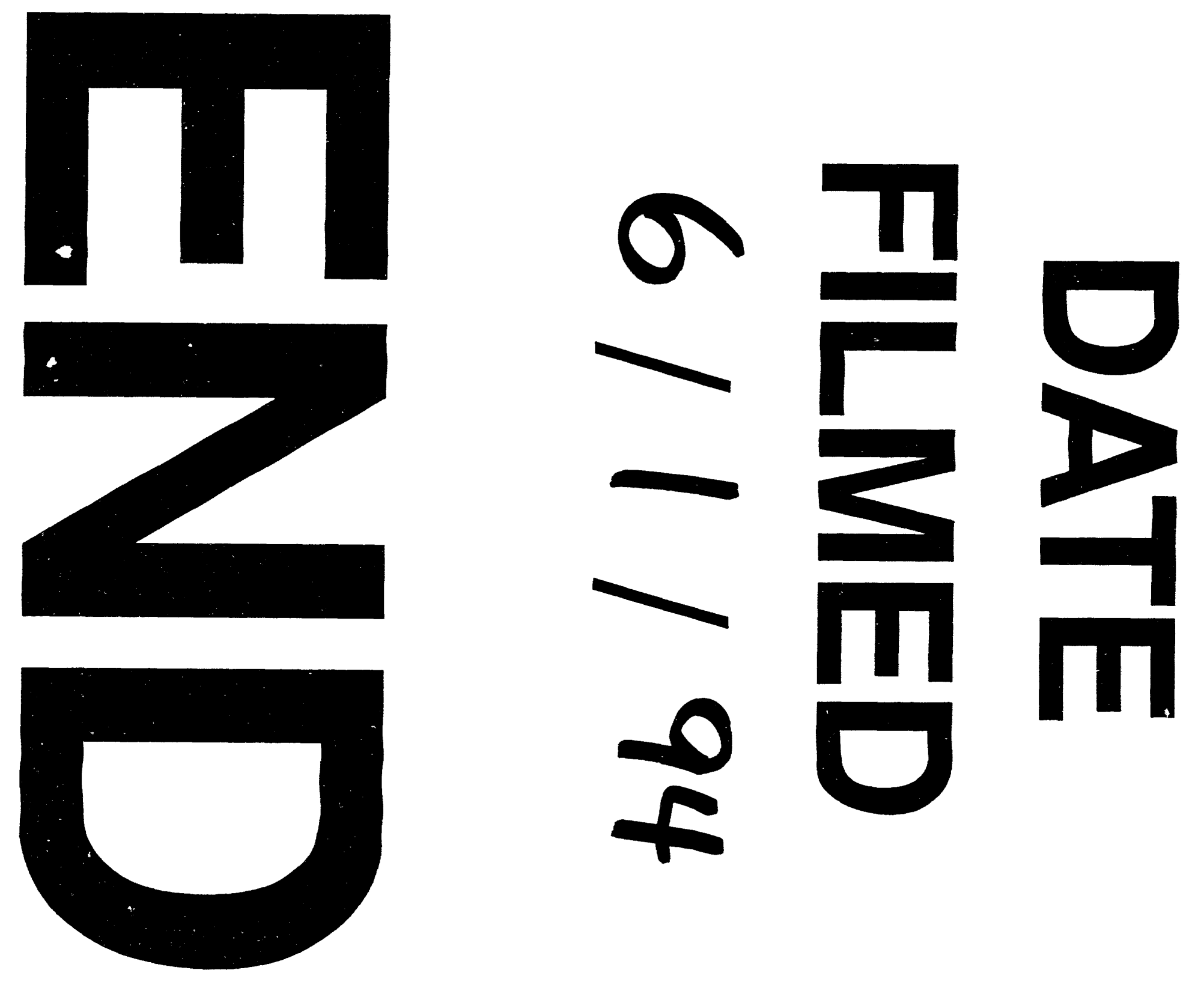